Nevada

Environmental

Restoration

Project

Corrective Action Investigation Plan for Corrective Action Unit 166:

Storage Yards and Contaminated Materials

Nevada Test Site, Nevada

Controlled Copy No.:

Revision No.: 0

June 2006

Approved for public release; further dissemination unlimited.

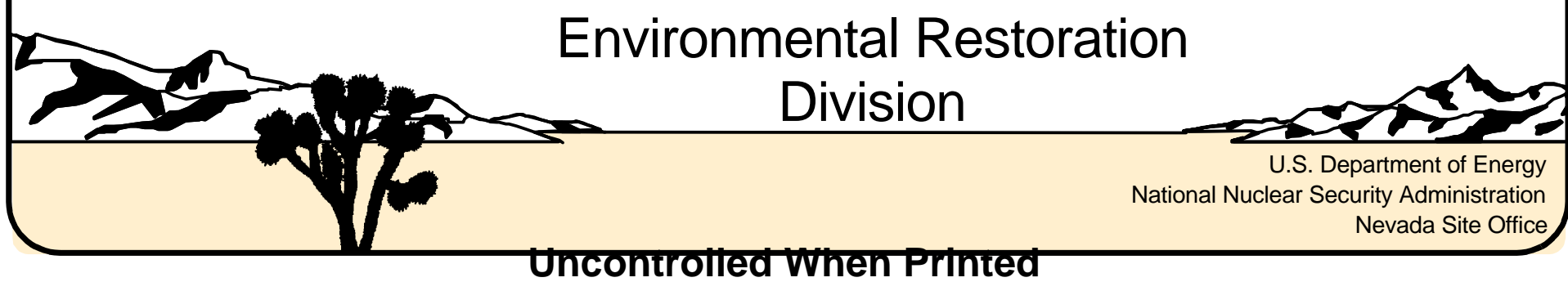


Available for sale to the public from:

U.S. Department of Commerce

National Technical Information Service

5285 Port Royal Road

Springfield, VA 22161

Phone: 800.553 .6847

Fax: 703.605.6900

Email: orders@ntis.gov

Online ordering: http://www.ntis.gov/ordering.htm

Available electronically at http://www.osti.gov/bridge

Available for a processing fee to U.S. Department of Energy and its contractors, in paper, from:

U.S. Department of Energy

Office of Scientific and Technical Information

P.O. Box 62

Oak Ridge, TN 37831-0062

Phone: 865.576.8401

Fax: 865.576.5728

Email: reports@adonis.osti.gov

Reference herein to any specific commercial product, process, or service by trade name, trademark, manufacturer, or otherwise, does not necessarily constitute or imply its endorsement, recommendation, or favoring by the United States Government or any agency thereof or its contractors or subcontractors. 


\title{
CORRECTIVE ACTION INVESTIGATION PLAN FOR CORRECTIVE ACTION UNIT 166: STORAGE YARDS AND CONTAMINATED MATERIALS NEVADA TEST SITE, NEVADA
}

\author{
U.S. Department of Energy \\ National Nuclear Security Administration \\ Nevada Site Office \\ Las Vegas, Nevada
}

Controlled Copy No.:

Revision No.: 0

June 2006

Approved for public release; further dissemination unlimited. 


\section{CORRECTIVE ACTION INVESTIGATION PLAN FOR CORRECTIVE ACTION UNIT 166: STORAGE YARDS AND CONTAMINATED MATERIALS \\ NEVADA TEST SITE, NEVADA}

\section{Approved by: APPROVED SIGNATURE \\ Date: 6/15/2006 \\ Sabine Curtis \\ Acting Federal Sub-Project Director \\ Environmental Restoration Project}

\footnotetext{
Approved by:

Janet Appenzeller-Wing

Federal Project Director

Environmental Restoration Project
} 


\section{Table of Contents}

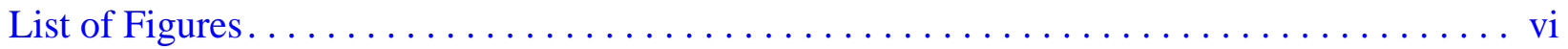

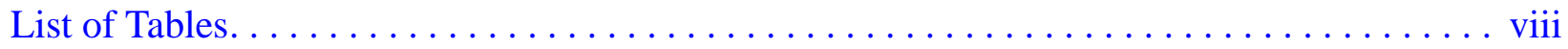

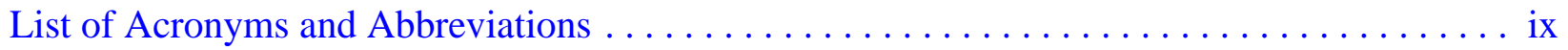

Executive Summary . . . . . . . . . . . . . . . . . . . . . ES-1

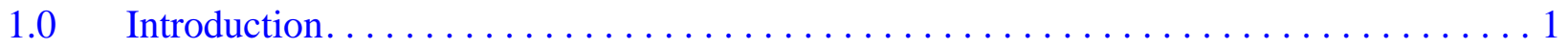

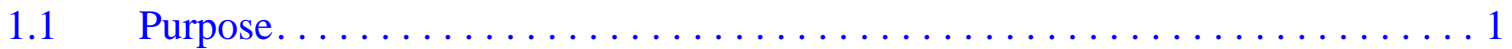

1.1.1 Corrective Action Unit 166 History and Description . . . . . . . . . 3

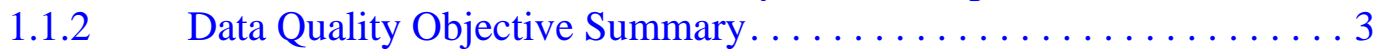

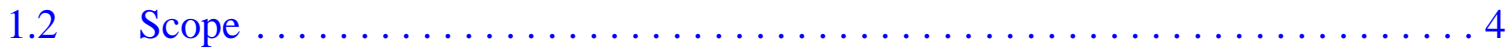

1.3 Corrective Action Investigation Plan Contents . . . . . . . . . . . . . 5

$2.0 \quad$ Facility Description. . . . . . . . . . . . . . . . 6

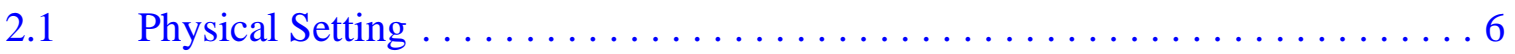

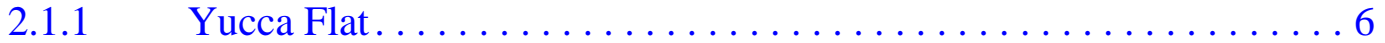

2.1.2 Frenchman Flat......................... 7

2.1.3 Alkali Flat Furnace Creek Ranch Subbasin . . . . . . . . . . . . . . . . 8

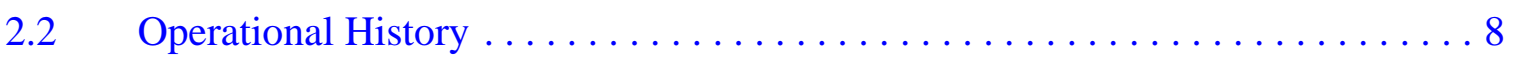

2.2.1 Corrective Action Sites 02-42-01, Cond. Release

Storage Yd - North; 02-42-02, Cond. Release

Storage Yd - South; 02-99-10, D-38 Storage Area. . . . . . . . . . . . 8

2.2.2 Corrective Action Site 03-42-01, Conditional Release

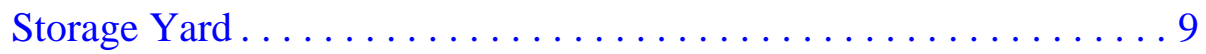

2.2.3 Corrective Action Site 05-19-02, Contaminated Soil

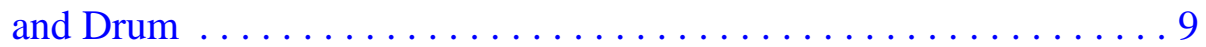

2.2.4 Corrective Action Sites 18-01-01, Aboveground Storage Tank, and 18-99-03, Wax Piles/Oil Stain . . . . . . . . . . . . . . . 9

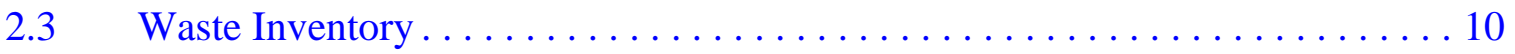

2.3.1 Corrective Action Sites 02-42-01, Cond. Release Storage

Yd - North; 02-42-02 Cond. Release Storage Yd - South;

02-99-10, D-38 Storage Area . . . . . . . . . . . . . . . . . 10

2.3.2 Corrective Action Site 03-42-01, Conditional Release

Storage Yard ....................... 10

2.3.3 Corrective Action Site 05-19-02, Contaminated Soil and Drum . . . . 10

2.3.4 Corrective Action Sites 18-01-01, Aboveground Storage Tank, and 18-99-03, Wax Piles/Oil Stain . . . . . . . . . . . . . 11

$2.4 \quad$ Release Information . . . . . . . . . . . . . . . . . . 11

2.4.1 Corrective Action Sites 02-42-01, Cond. Release

Storage Yd - North; 02-42-02, Cond. Release

Storage Yd - South; 02-99-10, D-38 Storage Area. . . . . . . . . . . 12

2.4.2 Corrective Action Site 03-42-01, Conditional Release

Storage Yard ......................... 12 


\section{Table of Contents (Continued)}

2.4.3 Corrective Action Site 05-19-02, Contaminated Soil and Drum . . . 12

2.4.4 Corrective Action Sites 18-01-01, Aboveground Storage Tank, and 18-99-03, Wax Piles/Oil Stain . . . . . . . . . . . . . 13

2.5 Investigative Background. . . . . . . . . . . . . . . . 13

2.5.1 Corrective Action Sites 02-42-01, Cond. Release Storage Yd - North; 02-42-02, Cond. Release Storage Yd - South; 02-99-10, D-38 Storage Area. . . . . . . . . . . . 13

2.5.2 Corrective Action Site 03-42-01, Conditional Release Storage Yard ......................... 13

2.5.3 Corrective Action Site 05-19-02, Contaminated Soil and Drum . . . 14

2.5.4 Corrective Action Sites 18-01-01, Aboveground Storage Tank, and 18-99-03, Wax Piles/Oil Stain . . . . . . . . . . . . . . . 15

2.5.5 National Environmental Policy Act . . . . . . . . . . . . . . . . . 15

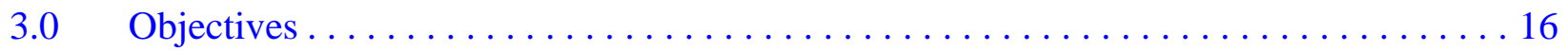

3.1 Conceptual Site Model. . . . . . . . . . . . . . . . . . . . 16

3.1.1 Land Use and Exposure Scenarios . . . . . . . . . . . . 16

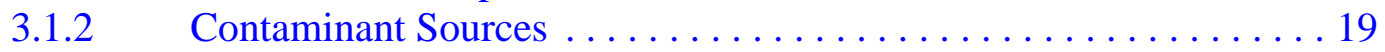

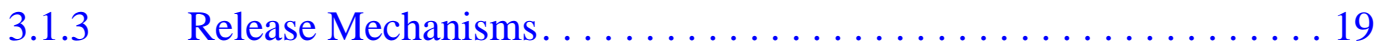

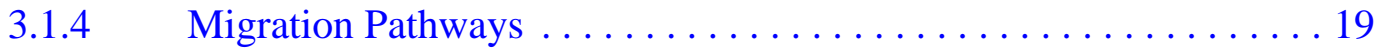

Exposure Points . . . . . . . . . . . . . . . . . . . . 21

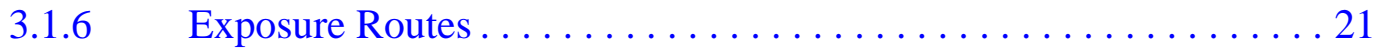

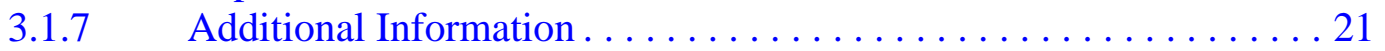

3.2 Contaminants of Potential Concern ..................... 21

3.3 Preliminary Action Levels . . . . . . . . . . . . . . . . . . 25

3.3.1 Chemical PALs. . . . . . . . . . . . . . . . . . 27

3.3.2 Total Petroleum Hydrocarbon PALs . . . . . . . . . . . . 27

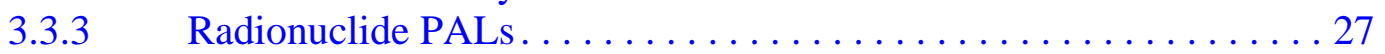

3.4 Data Quality Objective Process Discussion. . . . . . . . . . . . . 28

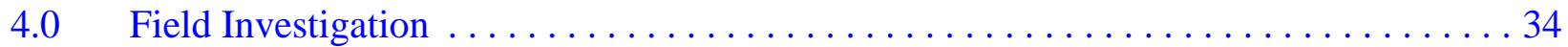

4.1 Technical Approach . . . . . . . . . . . . . . . . . . . . 34

4.2 Field Activities. . . . . . . . . . . . . . . . . . . . . . . 35

4.2.1 Site Preparation Activities . . . . . . . . . . . . . . . . 35

4.2.2 Sample Location Selection . . . . . . . . . . . . . . . . . . . 35

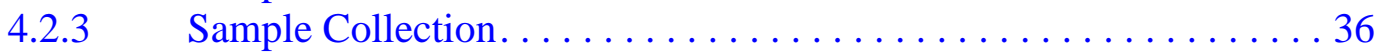

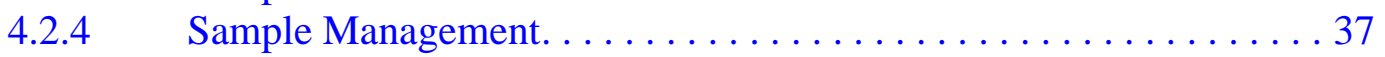

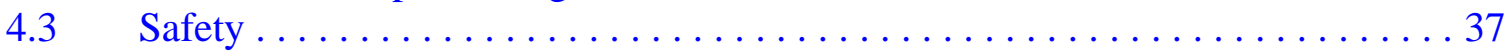

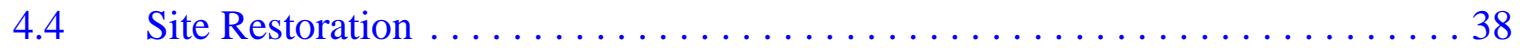

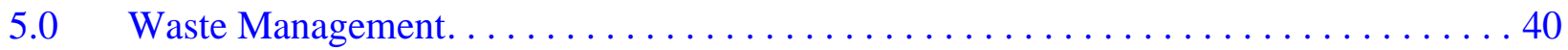




\section{Table of Contents (Continued)}

$5.1 \quad$ Waste Minimization. ................................ 40

$5.2 \quad$ Potential Waste Streams. ............................. 41

$5.3 \quad$ Investigation-Derived Waste Management $\ldots \ldots \ldots \ldots \ldots \ldots \ldots \ldots . \ldots 41$

5.3.1 Sanitary Waste $\ldots \ldots \ldots \ldots \ldots \ldots \ldots \ldots \ldots \ldots \ldots \ldots \ldots \ldots \ldots \ldots$

5.3.2 Low-Level Radioactive Waste ................... 43

$5.3 .3 \quad$ Hazardous Waste . . . . . . . . . . . . . . . . . . . . . . 44

$5.3 .4 \quad$ Hydrocarbon Waste . ........................... 44

5.3.5 Mixed Low-Level Waste . . . . . . . . . . . . . . . . . 44

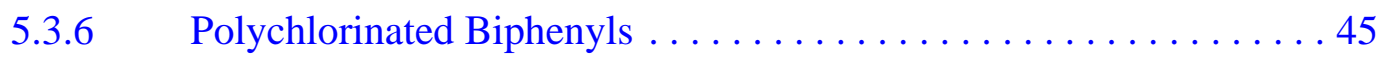

$5.4 \quad$ Management of Specific Waste Streams ....................... 45

$5.4 .1 \quad$ Personal Protective Equipment.................. 45

5.4.2 Management of Decontamination Rinsate ................ 46

5.4.3 Management of Soil ........................... 47

$5.4 .4 \quad$ Management of Debris . . . . . . . . . . . . . . . . . 47

5.4.5 Field-Screening Waste $\ldots \ldots \ldots \ldots \ldots \ldots \ldots \ldots \ldots \ldots$

6.0 Quality Assurance/Quality Control $\ldots \ldots \ldots \ldots \ldots \ldots \ldots \ldots \ldots \ldots \ldots$

6.1 Quality Control Sampling Activities ..................... 49

$6.2 \quad$ Laboratory/Analytical Quality Assurance $\ldots \ldots \ldots \ldots \ldots \ldots \ldots \ldots \ldots \ldots$

6.2.1 Data Validation........................... 50

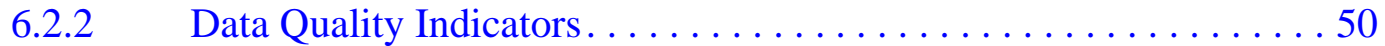

6.2.3 Precision ................................... 52

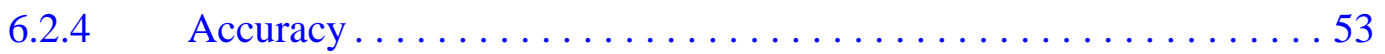

$6.2 .5 \quad$ Representativeness .......................... 54

6.2.6 Completeness ............................... 54

$6.2 .7 \quad$ Comparability ............................. 55

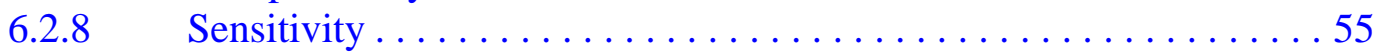

$7.0 \quad$ Duration and Records Availability . . . . . . . . . . . . . . . . . . 56

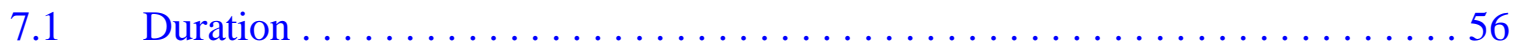

$7.2 \quad$ Records Availability..................................... 56

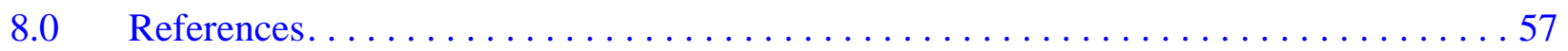

\section{Appendix A - Data Quality Objectives}

A.1.0 Introduction. . . . . . . . . . . . . . . . . . . . .

A.2.0 Background Information. $\ldots \ldots \ldots \ldots \ldots \ldots \ldots \ldots \ldots \ldots \ldots \ldots \ldots \ldots \ldots \ldots \ldots \ldots \ldots \ldots$

A.2.1 Corrective Action Site 02-42-01, Cond. Release Storage Yd - North . . . . . . . A-2

A.2.2 Corrective Action Site 02-42-02, Cond. Release Storage Yd - South . . . . . . . A-5

A.2.3 Corrective Action Site 02-99-10, D-38 Storage Area ............... A-8 


\section{Table of Contents (Continued)}

A.2.4 Corrective Action Site 03-42-01, Conditional Release Storage Yard . . . . . . A A-10

A.2.5 Corrective Action Site 05-19-02, Contaminated Soil and Drum. .......... A-14

A.2.6 Corrective Action Site 18-01-01, Aboveground Storage Tank . . . . . . . . . . A A-19

A.2.7 Corrective Action Site 18-99-03, Wax Piles/Oil Stain . . . . . . . . . . . A-22

A.3.0 Step 1 - State the Problem............................... A-29

A.3.1 Planning Team Members .......................... A-29

A.3.2 Conceptual Site Model. .......................... A-30

A.3.2.1 Contaminant Release ...................... A-31

A.3.2.2 Potential Contaminants....................... A-31

A.3.2.3 Contaminant Characteristics .................... A-35

A.3.2.4 Site Characteristics ...................... A-35

A.3.2.5 Migration Pathways and Transport Mechanisms ........... A-36

A.3.2.6 Exposure Scenarios....................... A-37

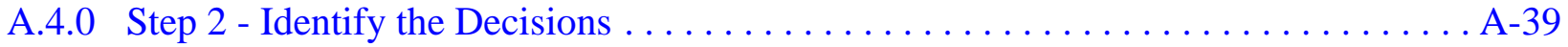

A.4.1 Decision Statements. ............................ A-39

A.4.2 Alternative Actions to the Decisions .................... A-40

A.4.2.1 Alternative Actions to Decision I . . . . . . . . . . . . . A-40

A.4.2.2 Alternative Actions to Decision II ............... A-40

A.5.0 Step 3 - Identify the Inputs to the Decision $\ldots \ldots \ldots \ldots \ldots \ldots \ldots \ldots \ldots \ldots \ldots \ldots \ldots \ldots$

A.5.1 Information Needs . . . . . . . . . . . . . . . . . . . . . . A-41

A.5.2 Sources of Information. .........................

A.5.2.1 Sample Locations ......................... A-42

A.5.2.1.1 Judgmental Approach for Sampling Location Selection .......................... A-42

A.5.2.1.2 Probabilistic Approach for Sample Location Selection ........................... A-44

A.5.2.2 Analytical Methods........................ A-45

A.6.0 Step 4 - Define the Boundaries of the Study $\ldots \ldots \ldots \ldots \ldots \ldots \ldots \ldots \ldots$ A-46

A.6.1 Populations of Interest . . . . . . . . . . . . . . . . . . . . . A-46

A.6.2 Spatial Boundaries ................................. A-46

A.6.3 Practical Constraints. ............................... A 46

A.6.4 Define the Scale of Decision Making . . . . . . . . . . . . . . . . . . . A-47

A.7.0 Step 5 - Develop a Decision Rule ......................... A-48

A.7.1 Population Parameters . . . . . . . . . . . . . . . . . . . . . . . . . A 48

A.7.2 Decision Rules ................................... A-48

A.7.3 Action Levels . . . . . . . . . . . . . . . . . . . . . . . . . . . . . A-49 


\section{Table of Contents (Continued)}

A.7.3.1 Chemical PALs........................ A-50

A.7.3.2 Total Petroleum Hydrocarbon PALs $\ldots \ldots \ldots \ldots \ldots \ldots \ldots$ A-51

A.7.3.3 Radionuclide PALs........................ A-51

A.7.4 Measurement and Analysis Sensitivity $\ldots \ldots \ldots \ldots \ldots \ldots \ldots \ldots \ldots$ A-51

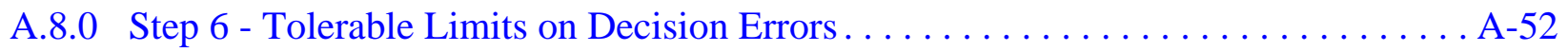

A.8.1 False Negative Decision Error . . . . . . . . . . . . . . . . A-53

A.8.1.1 False Negative Decision Error for Judgmental Sampling . . . . . . A-53

A.8.1.2 False Negative Decision Error for Probabilistic Sampling. . . . . . A A-55

A.8.2 False Positive Decision Error. ...................... A-55

A.8.2.1 False Positive Decision Error for Judgmental Sampling ........ A-56

A.8.2.2 False Positive Decision Error for Probabilistic Sampling ....... A-56

A.9.0 Step 7 - Optimize the Design for Obtaining Data................. A-57

A.9.1 Judgmental Sampling. ........................... A-57

A.9.2 Probabilistic Sampling . . . . . . . . . . . . . . . . . . . . . . . 58

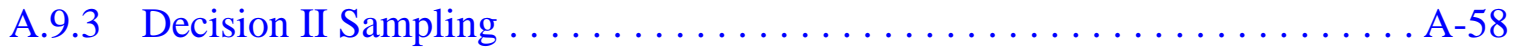

A.9.4 Corrective Action Sites 02-42-01, Cond. Release

Storage Yd - North; 02-42-02, Cond. Release Storage Yd - South;

02-99-10, D-38 Storage Area....................... A-59

A.9.5 Corrective Action Site 03-42-01, Conditional Release Storage Yard . . . . . . A-63

A.9.6 Corrective Action Site 05-19-02, Contaminated Soil and Drum. . . . . . . . . A-65

A.9.7 Corrective Action Sites 18-01-01, Aboveground Storage Tank, and 18-99-03, Wax Piles/Oil Stain. .................... A-67

A.10.0 References.................................... A-72

\section{Appendix B - Project Organization}

B.1.0 Project Organization . . . . . . . . . . . . . . . . . . . . . . .

Appendix C - Determination of the Number and Location of Random Samples

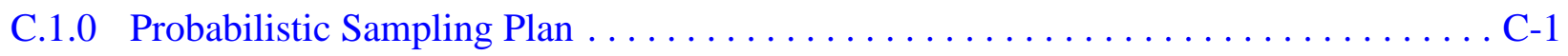

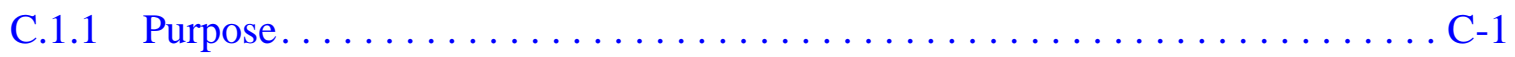

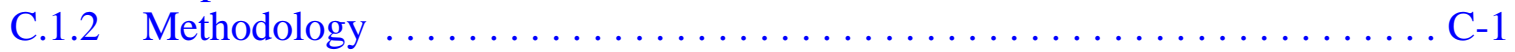

C.1.2.1 Computation of the Upper Confidence Limit............ C-2

C.1.2.2 Sample Size............................ C-2

C.1.2.3 Sample Location Selection ...................... C-3

C.2.0 References................................. -5

Appendix D - Nevada Division of Environmental Protection Comments 


\section{List of Figures}

Number

Title

Page

1-1 Nevada Test Site Map with CAU 166 CAS Locations . . . . . . . . . . . . . 2

3-1 Conceptual Site Model Diagram . . . . . . . . . . . . . . . . . 17

3-2 Corrective Action Unit 166 Conceptual Site Model . . . . . . . . . . . . 18

3-3 Risk-Based Corrective Action Decision Process $\ldots \ldots \ldots \ldots \ldots \ldots \ldots$

A.2-1 Corrective Action Unit 166, CAS Location Map ................ A-3

A.2-2 Site Sketch of CAS 02-42-01, Cond. Release Storage Yd - North . . . . . . . . . A-4

A.2-3 Site Sketch of CAS 02-42-02, Cond. Release Storage Yd - South . . . . . . . . . . A-6

A.2-4 Site Sketch of CAS 02-99-10, D-38 Storage Area $\ldots \ldots \ldots \ldots \ldots \ldots \ldots \ldots$ A-9

A.2-5 Site Sketch of CAS 03-42-01, Conditional Release Storage Yard . . . . . . . A-11

A.2-6 Site Sketch of Radioactive Material Area in CAS 03-42-01, Conditional Release Storage Yard. . . . . . . . . . . . . . . . A A-12

A.2-7 Historical Photograph of CAS 03-42-01, Conditional Release Storage Yard. . . A-13

A.2-8 Material Remaining in CAS 03-42-01, Conditional Release Storage Yard . . . . A-15

A.2-9 Material Remaining in CAS 03-42-01, Conditional Release Storage Yard . . . . A-16

A.2-10 Site Sketch of CAS 05-19-02, Contaminated Soil and Drum . . . . . . . . . . A-18

A.2-11 Overview Sketch of CAS 18-01-01, Aboveground Storage Tank and CAS 18-99-03, Wax Piles/Oil Stain . . . . . . . . . . . . . A-20

A.2-12 Site Sketch of CAS 18-01-01, Aboveground Storage Tank . . . . . . . . . A-21

A.2-13 Photograph of CAS 18-01-01, Aboveground Storage Tank . . . . . . . . . . A-23

A.2-14 Site Sketch of Site A in CAS 18-99-03, Wax Piles/Oil Stain . . . . . . . . . . . A-24 


\section{List of Figures (Continued)}

Number

Title

Page

A.2-15 Site Sketch of Site B in CAS 18-99-03, Wax Piles/Oil Stain . . . . . . . . . . A A-25

A.2-16 Photograph of the Metal Container at Site B (CAS 18-99-03) . . . . . . . . . . A-27

A.2-17 Photograph of the Wax Pile/Hardened Residue at Site B (CAS 18-99-03) . . . . A-28

A.3-1 Conceptual Site Model for CAU $166 \ldots \ldots \ldots \ldots \ldots \ldots \ldots \ldots \ldots \ldots$. . . . . . . . .

A.9-1 Proposed Sample Locations at CAS $02-42-01 \ldots \ldots \ldots \ldots \ldots \ldots \ldots$. . . . . . . .

A.9-2 Proposed Sample Locations at CAS $02-42-02 \ldots \ldots \ldots \ldots \ldots \ldots \ldots \ldots$. . . . . . . . . .

A.9-3 Proposed Sample Locations at CAS $02-99-10 \ldots \ldots \ldots \ldots \ldots \ldots \ldots \ldots \ldots$. . . . . . . .

A.9-4 Proposed Sample Locations at CAS 03-42-01 . . . . . . . . . . . . . . . A-64

A.9-5 Proposed Sample Locations at CAS $05-19-02 \ldots \ldots \ldots \ldots \ldots \ldots \ldots$. . . . . . . . .

A.9-6 Proposed Sample Locations at CAS $18-01-01 \ldots \ldots \ldots \ldots \ldots \ldots \ldots$. . . . . . . . . . .

A.9-7 Proposed Sample Locations at Site A, CAS $18-99-03 \ldots \ldots \ldots \ldots \ldots \ldots$. . . . . . .

A.9-8 Proposed Sample Locations at Site B, CAS $18-99-03 \ldots \ldots \ldots \ldots \ldots \ldots$. . . . . . . .

C.1-1 Decision Performance Goal Diagram . . . . . . . . . . . . . . . C-4 


\section{List of Tables}

Number

Title

Page

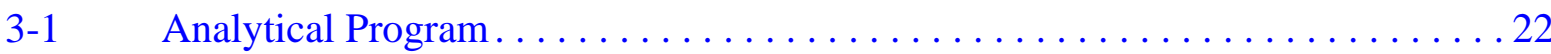

3-2 Constituents Reported by Analytical Methods ..................... 23

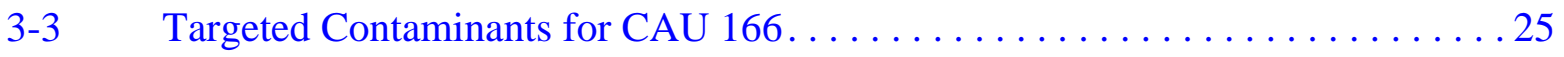

3-4 Analytical Requirements for Radionuclides for CAU $166 \ldots \ldots \ldots \ldots \ldots 31$

3-5 Analytical Requirements for Chemical COPCs for CAU $166 \ldots \ldots \ldots \ldots . \ldots 32$

5-1 Waste Management Regulations and Requirements ................ 42

6-1 Laboratory and Analytical Performance Criteria for CAU 166

Data Quality Indicators.................................. 51

7-1 Corrective Action Investigation Activity Durations................ 56

A.3-1 Final DQO Meeting Participants for CAU 166

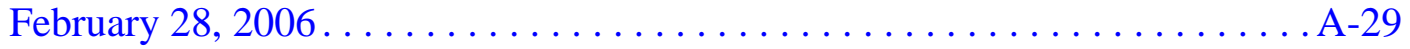

A.3-2 Conceptual Site Model Description of Elements for Each CAS

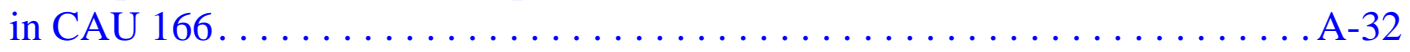

A.3-3 Future Land-Use Zones and Exposure Scenarios................. A-37

A.5-1 Parameter Values for Calculating Sample Size $\ldots \ldots \ldots \ldots \ldots \ldots \ldots$ A-45

A.6-1 Spatial Boundaries of CAU 166 CASs ..................... A-47

C.1-1 Parameter Values for Calculating Sample Size $\ldots \ldots \ldots \ldots \ldots \ldots \ldots \ldots$ C-3 


\section{List of Acronyms and Abbreviations}

ASTM American Society for Testing and Materials

bgs Below ground surface

BN Bechtel Nevada

CADD Corrective Action Decision Document

CAI Corrective Action Investigation

CAIP Corrective Action Investigation Plan

CAS Corrective Action Site

CAU Corrective Action Unit

CFR Code of Federal Regulations

COC Contaminant of concern

COPC Contaminant of potential concern

CSM Conceptual site model

DoD U.S. Department of Defense

DOE U.S. Department of Energy

DOT U.S. Department of Transportation

DQI Data quality indicator

DQO Data quality objective

DRI Desert Research Institute

DRO Diesel-range organics

EPA U.S. Environmental Protection Agency

EQL $\quad$ Estimated quantitation limit

ERDA U.S. Energy Research and Development Administration

FAL Final action level

FFACO Federal Facility Agreement and Consent Order 


\section{Acronyms and Abbreviations (Continued)}

\begin{tabular}{|c|c|}
\hline $\mathrm{ft}$ & Foot \\
\hline $\mathrm{ft}^{2}$ & Square feet \\
\hline FWP & Field Work Permit \\
\hline HWAA & Hazardous waste accumulation area \\
\hline IDW & Investigation-derived waste \\
\hline in. & Inch \\
\hline IS HASP & Industrial Sites Health and Safety Plan \\
\hline ISMS & Integrated Safety Management System \\
\hline LANL & Los Alamos National Laboratory \\
\hline LCS & Laboratory control sample \\
\hline LCSD & Laboratory control sample duplicate \\
\hline LLNL & Lawrence Livermore National Laboratory \\
\hline MDC & Minimum detectable concentration \\
\hline $\mathrm{mg} / \mathrm{kg}$ & Milligrams per kilogram \\
\hline $\mathrm{mg} / \mathrm{L}$ & Milligrams per liter \\
\hline mi & Mile \\
\hline mrem/yr & Millirem per year \\
\hline MS & Matrix spike \\
\hline MSD & Matrix spike duplicate \\
\hline N/A & Not applicable \\
\hline NAC & Nevada Administrative Code \\
\hline NCRP & National Council on Radiation Protection and Measurement \\
\hline ND & Normalized difference \\
\hline NDEP & Nevada Division of Environmental Protection \\
\hline
\end{tabular}




\section{Acronyms and Abbreviations (Continued)}

NEPA National Environmental Policy Act

NNSA/NSO U.S. Department of Energy, National Nuclear Security Administration Nevada Site Office

NRS Nevada Revised Statutes

NTS Nevada Test Site

NTSWAC Nevada Test Site Waste Acceptance Criteria

PAL Preliminary action level

PCB Polychlorinated biphenyl

pCi/g Picocuries per gram

$\mathrm{pCi} / \mathrm{L} \quad$ Picocuries per liter

POC Performance Objective for the Certification of Nonradioactive Hazardous Waste

PPE Personal protective equipment

ppm Parts per million

PRG Preliminary remediation goal

QA Quality assurance

QAPP Quality Assurance Project Plan

QC Quality control

RadCon Radiological control

RBCA Risk-based corrective action

RCA Radiologically controlled area

RCRA Resource Conservation and Recovery Act

RL Reporting limit

RMA Radioactive material area

RPD Relative percent difference 


\section{Acronyms and Abbreviations (Continued)}

$\begin{array}{ll}\text { SDWS } & \text { Safe Drinking Water Standards } \\ \text { SNJV } & \text { Stoller-Navarro Joint Venture } \\ \text { SSTL } & \text { Site-specific target level } \\ \text { SVOC } & \text { Semivolatile organic compound } \\ \text { TPH } & \text { Total petroleum hydrocarbons } \\ \text { TSCA } & \text { Toxic Substance Control Act } \\ \text { UCL } & \text { Upper confidence level } \\ \text { UGTA } & \text { Underground Test Area } \\ \text { USGS } & \text { U.S. Geological Survey } \\ \text { UST } & \text { Underground storage tank } \\ \text { VOC } & \text { Volatile organic compound } \\ \text { VSP } & \text { Visual Sample Plan } \\ \text { \%R } & \text { Percent recovery }\end{array}$




\section{Executive Summary}

Corrective Action Unit 166 is located in Areas 2, 3, 5, and 18 of the Nevada Test Site, which is 65 miles northwest of Las Vegas, Nevada. Corrective Action Unit (CAU) 166 is comprised of the seven Corrective Action Sites (CASs) listed below:

- 02-42-01, Cond. Release Storage Yd - North

- 02-42-02, Cond. Release Storage Yd - South

- 02-99-10, D-38 Storage Area

- 03-42-01, Conditional Release Storage Yard

- 05-19-02, Contaminated Soil and Drum

- 18-01-01, Aboveground Storage Tank

- 18-99-03, Wax Piles/Oil Stain

These sites are being investigated because existing information on the nature and extent of potential contamination is insufficient to evaluate and recommend corrective action alternatives. Additional information will be obtained by conducting a corrective action investigation (CAI) before evaluating corrective action alternatives and selecting the appropriate corrective action for each CAS. The results of the field investigation will support a defensible evaluation of viable corrective action alternatives that will be presented in the Corrective Action Decision Document.

The sites will be investigated based on the data quality objectives (DQOs) developed on February 28, 2006, by representatives of the Nevada Division of Environmental Protection; U.S. Department of Energy, National Nuclear Security Administration Nevada Site Office; Stoller-Navarro Joint Venture; and Bechtel Nevada. The DQO process was used to identify and define the type, amount, and quality of data needed to develop and evaluate appropriate corrective actions for CAU 166.

Appendix A provides a detailed discussion of the DQO methodology and the DQOs specific to each CAS.

The scope of the CAI for CAU 166 includes the following activities:

- Move surface debris and/or materials, as needed, to facilitate sampling.

- Conduct radiological surveys. 
- Perform field screening.

- Collect and submit environmental samples for laboratory analysis to determine if contaminants of concern are present.

- If contaminants of concern are present, collect additional step-out samples to define the extent of the contamination.

- Collect samples of investigation-derived waste, as needed, for waste management and minimization purposes.

This Corrective Action Investigation Plan has been developed in accordance with the Federal Facility Agreement and Consent Order that was agreed to by the State of Nevada, the U.S. Department of Energy, and the U.S. Department of Defense. Under the Federal Facility Agreement and Consent Order, this Corrective Action Investigation Plan will be submitted to the Nevada Division of Environmental Protection, and field work will commence following approval. 


\subsection{Introduction}

This Corrective Action Investigation Plan (CAIP) contains project-specific information including facility descriptions, environmental sample collection objectives, and criteria for conducting site investigation activities at Corrective Action Unit (CAU) 166: Storage Yards and Contaminated Materials, Nevada Test Site (NTS), Nevada.

This CAIP has been developed in accordance with the Federal Facility Agreement and Consent Order (FFACO) (1996) that was agreed to by the State of Nevada, the U.S. Department of Energy (DOE), and the U.S. Department of Defense (DoD).

Corrective Action Unit 166 is located in Areas 2, 3, 5, and 18 of the NTS, which is approximately 65 miles (mi) northwest of Las Vegas, Nevada (Figure 1-1). Corrective Action Unit 166 is comprised of the seven Corrective Action Sites (CASs) shown on Figure 1-1 and listed below:

- CAS 02-42-01, Cond. Release Storage Yd - North

- CAS 02-42-02, Cond. Release Storage Yd - South

- CAS 02-99-10, D-38 Storage Area

- CAS 03-42-01, Conditional Release Storage Yard

- CAS 05-19-02, Contaminated Soil and Drum

- CAS 18-01-01, Aboveground Storage Tank

- CAS 18-99-03, Wax Piles/Oil Stain

The Corrective Action Investigation (CAI) will include field inspections, radiological surveys, sampling of environmental media, analysis of samples, and assessment of investigation results, where appropriate. Data will be obtained to support corrective action alternative evaluations and waste management decisions.

\subsection{Purpose}

The CASs in CAU 166 are being investigated because hazardous and/or radioactive constituents may be present in concentrations that could potentially pose a threat to human health and the environment. Existing information on the nature and extent of potential contamination is insufficient to evaluate and recommend corrective action alternatives for the CASs. Additional information will be generated by conducting a CAI before evaluating and selecting corrective action alternatives. 


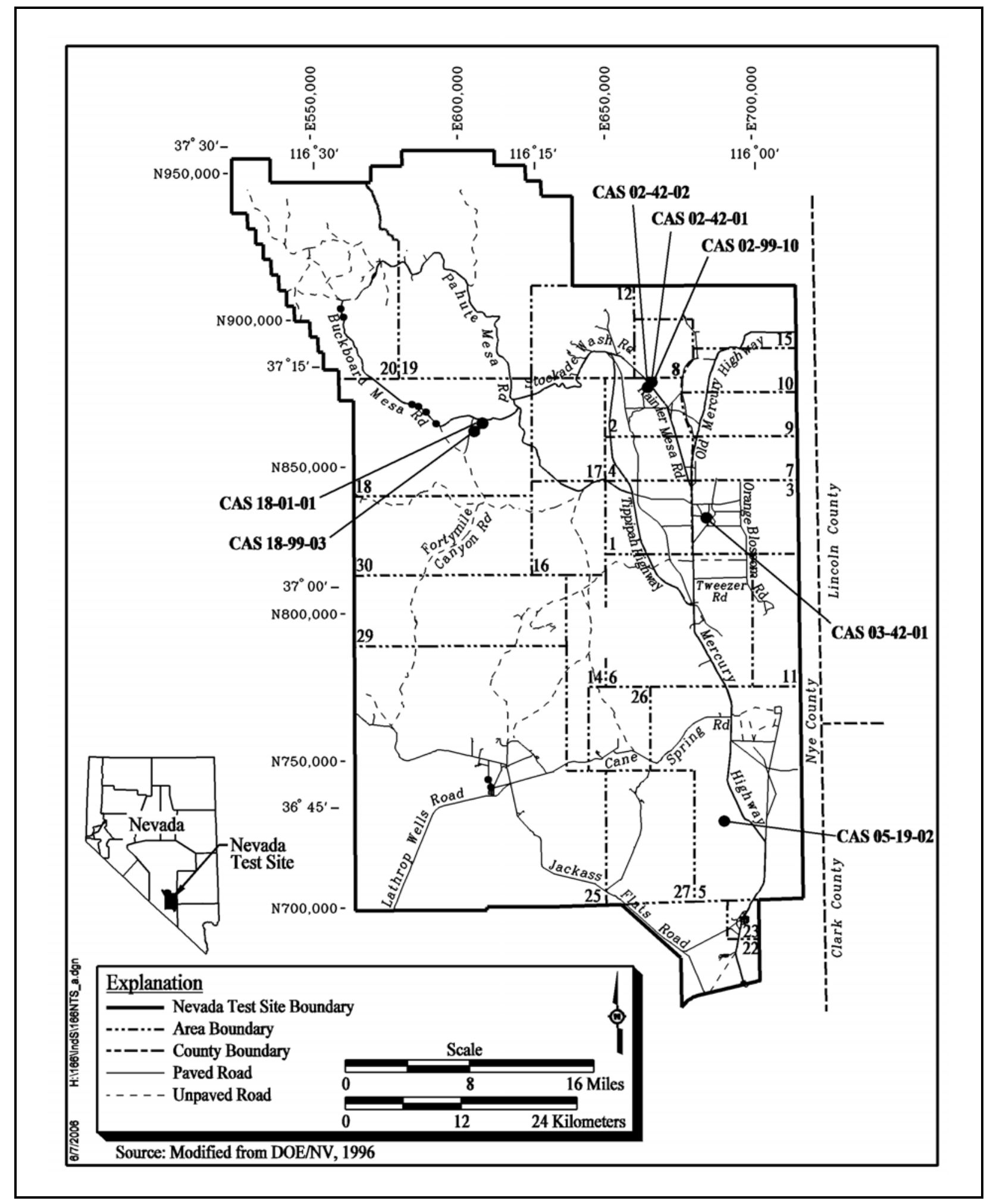

Figure 1-1

Nevada Test Site Map with CAU 166 CAS Locations 


\subsubsection{Corrective Action Unit 166 History and Description}

Corrective Action Unit 166, Storage Yards and Contaminated Materials, consists of seven inactive sites located in Areas 2, 3, 5, and 18. The seven CAU 166 sites consist of storage yards, drum in a wash, wax piles/hardened residue, and metal containers with open holes. The CAU 166 sites were all used to support nuclear testing conducted in the Yucca Flat, Frenchman Flat, and Alkali Flat Furnace Creek Ranch Subbasin. Operational histories for each CAU 166 CAS are detailed in Section 2.2.

\subsubsection{Data Quality Objective Summary}

The sites will be investigated based on data quality objectives (DQOs) developed by representatives of the Nevada Division of Environmental Protection (NDEP); U.S. Department of Energy, National Nuclear Security Administration Nevada Site Office (NNSA/NSO); Stoller-Navarro Joint Venture (SNJV); and Bechtel Nevada (BN). The DQOs are used to identify and define the type, amount, and quality of data needed to develop and evaluate appropriate corrective actions for CAU 166. This CAIP describes the investigative approach developed to collect the data needs identified in the DQO process. While a detailed discussion of the DQO methodology and the DQOs specific to each CAS are presented in Appendix A of this document, a summary of the DQO process is provided below.

The DQO problem statement for CAU 166 is: "Existing information on the nature and extent of potential contamination is insufficient to evaluate and recommend corrective action alternatives for the seven CASs in CAU 166." To address this question, the resolution of two decisions statements is required:

- Decision I: "Is any contaminant of potential concern (COPC) present in environmental media within the CAS at a concentration exceeding its corresponding final action level (FAL)?” For judgmental sampling, any contaminant associated with a CAS activity that is present at concentrations exceeding its corresponding FAL will be defined as a contaminant of concern (COC). For probabilistic sampling, any COPC for which 95 percent upper confidence level (UCL) of the mean exceeds its corresponding FAL will be defined as a COC. A COC may also be defined as a contaminant that, in combination with other like contaminants, is determined to jointly pose an unacceptable risk based on multiple constituent analysis (NNSA/NSO, 2006). If a COC is detected, then Decision II must be resolved. If a COC is not detected, the investigation for that CAS is complete.

- Decision II: "If a COC is present, is sufficient information available to evaluate potential corrective action alternatives?” Sufficient information is defined to include: 
- Identification of the lateral and vertical extent of COC contamination in media.

- Characterization of investigation-derived waste (IDW) for disposal.

- Determination of potential remediation waste types.

- Evaluation the feasibility of remediation alternatives.

The informational inputs and data needs to resolve the problem statement and the decision statements were generated as part of the DQO process for this CAU and are documented in Appendix A. The information necessary to resolve the DQO decisions will be generated for each CAU 166 CAS by collecting and analyzing samples generated during a field investigation. The presence and nature of contamination at each CAS will be determined by collecting and analyzing samples following these two criteria:

- For judgmental sampling, samples must be collected in areas most likely to contain a COC.

- For probabilistic sampling, samples must be collected from random locations within the CAS that represent contamination within the CAS.

If while defining the nature of contamination it is determined that COCs are present at a CAS, that CAS will be further addressed by determining the extent of contamination before evaluating corrective action alternatives.

\subsection{Scope}

To generate information needed to resolve the decision statements identified in the DQO processes, the scope of the CAI for CAU 166 includes the following activities:

- Move surface debris and/or materials, as needed, to facilitate sampling.

- Conduct radiological surveys.

- Perform field screening.

- Collect and submit environmental samples for laboratory analysis to determine whether COCs are present.

- If COCs are present, collect additional step-out samples to define the extent of the contamination. 
- Collect samples of source material to determine the potential for a release.

- Collect samples of IDW, as needed, for waste management and minimization purposes.

- Collect Quality Control (QC) samples.

Contamination of environmental media originating from activities not identified in the conceptual site model (CSM) of any CAS will not be considered as part of this CAU unless the CSM and the DQOs are modified to include the release. As such, contamination originating from these sources will not be considered for sample location selection, and/or will not be considered COCs for Decision II. If such contamination is present, the contamination will be identified as part of another CAS (either new or existing).

\subsection{Corrective Action Investigation Plan Contents}

Section 1.0 presents the purpose and scope of this CAIP, while Section 2.0 provides CAU 166 background information. Objectives of the investigation, including CSMs, are presented in Section 3.0. Field investigation and sampling activities are discussed in Section 4.0, and waste management issues for this project in Section 5.0. General field and laboratory quality assurance (QA) (including collection of QA samples) are presented in Section 6.0 and in the Industrial Sites Quality Assurance Project Plan (QAPP) (NNSA/NV, 2002a). The project schedule and records availability are discussed in Section 7.0, and Section 8.0 is a list of references.

Appendix A provides a detailed discussion of the DQO methodology and the DQOs specific to each CAS, while Appendix B contains project organization information. Appendix C contains the criteria used for selecting randomized sample locations.

The health and safety aspects of this project are documented in the Industrial Sites Health and Safety Plan (IS HASP) (SNJV, 2004) and will be supplemented with a site-specific Field Work Plan (FWP) developed before the start of field work. Public involvement activities are documented in the "Public Involvement Plan" contained in Appendix V of the FFACO (1996). The managerial aspects of this project are discussed in the Project Execution Plan (SNJV, 2005) and will be supplemented with a site-specific field management plan to be developed before field activities. 


\subsection{Facility Description}

Corrective Action Unit 166 is comprised of seven CASs that were grouped together based on technical similarities (sites where equipment and components used to support testing activities were stored or abandoned) and the agency responsible for closure. The seven CASs are located in Areas 2, 3, 5, and 18 and include CASs 02-42-01, 02-42-02, 02-99-10, 03-42-01, 05-19-02, 18-01-01, and 18-99-03. Descriptions of and figures for each CAS are in Appendix A.

\subsection{Physical Setting}

The following sections describe the general physical settings of Areas 2, 3, 5, and 18 of the NTS. General background information pertaining to topography, geology, hydrogeology, and climatology are provided for these specific areas of the NTS region in the Geologic Map of the Nevada Test Site, Southern Nevada (USGS, 1990); CERCLA Preliminary Assessment for DOE's Nevada Operations Office Nuclear Weapons Testing Areas (DRI, 1988); Final Environmental Impact Statement, Nevada Test Site, Nye County, Nevada (ERDA, 1977); and the Final Environmental Impact Statement for the Nevada Test Site and Off-Site Locations in the State of Nevada (DOE/NV, 1996).

Geological and hydrological setting descriptions for each of the CASs are detailed in the following subsections based on the hydrogeographic area in which they are located.

\subsubsection{Yucca Flat}

Corrective Action Sites 02-42-01, 02-42-02, 02-99-10, and 03-42-01 are located within the Yucca Flat Hydrographic Area of the NTS. Yucca Flat is a closed basin, which is slowly being filled with alluvial deposits eroding from the surrounding mountains (USGS, 1996). Carbonate rocks primarily underlie the alluvium in parts of Yucca Flat and form much of the surrounding mountains in this area (DOE/NV, 1996).

The direction of groundwater flow in Yucca Flat generally is from the northeast to southwest. Within the overlying alluvial and volcanic aquifers, lateral groundwater flow occurs from the margins to the center of the basin and downward into the carbonate aquifer (USGS, 1996). The average annual precipitation at Station UCC on the Yucca Flat dry lake is 6.70 inches (in.) (ARL/SORD, 2006). The 
recharge rate to the Yucca Flat area is relatively low due to the thickness of the unsaturated zone extending to more than 600 feet (ft) below ground surface (bgs) (USGS, 1996).

The nearest groundwater well to CASs 02-42-01, 02-42-01, and 02-99-10 is U.S. Geological Survey (USGS) WW-2, an active well located approximately 0.6 to $0.9 \mathrm{mi}$ (depending on the CAS) northeast of the CASs. The most recent recorded depth to the water table is approximately 2,052 ft bgs (USGS/DOE, 2006).

The nearest groundwater well to CASs 03-42-01 is USGS WW-A, an active well located approximately $500 \mathrm{ft}$ north of the CAS. The most recent recorded depth to the water table is approximately 1,600 ft bgs (USGS/DOE, 2006).

\subsubsection{Frenchman Flat}

Corrective Action Site 05-19-02 lies within the Frenchman Flat Hydrographic Area, a broad-lined closed basin surrounded by low-lying mountains that separate this area from the Mercury Valley Hydrographic Area to the south and from the Yucca Flat Hydrographic Area to the north (USGS, 1996). Erosion of the surrounding mountains has resulted in the accumulation of more than one thousand feet of alluvial deposits in some areas of Frenchman Flat. Volcanic rocks underlie the alluvium in the northern and western parts of Frenchman Flat and, where exposed, form the surrounding low-lying mountains. Carbonate rocks primarily underlie the alluvium in the eastern and southeastern parts of Frenchman Flat and form much of the surrounding mountains in this area (DOE/NV, 1996).

Groundwater flow beneath the Frenchman Flat area occurs primarily within the carbonate-rock aquifer. Generally, the direction of groundwater flow in this region of the aquifer is from the northeast to southwest. Within the overlying alluvial and volcanic aquifers, lateral groundwater flow occurs from the margins to the center of the basin, and downward into the carbonate-rock aquifer. The hydraulic gradient in most areas of the alluvial aquifer in Frenchman Flat is relatively flat (less than $1 \mathrm{ft} / \mathrm{mi}$ ) except near active water wells and/or test wells (USGS, 1996). The average annual precipitation at station Well $5 \mathrm{~B}$, which is located near Frenchman Flat, is 4.92 in. (ARL/SORD, 2006). The recharge rate to the Frenchman Flat area is relatively low due to the thick unsaturated zone extending to more than $600 \mathrm{ft}$ bgs (USGS, 1996). 
The nearest groundwater well to CAS 05-19-02 is WW-5a, an active well located approximately $3.7 \mathrm{mi}$ northeast of the CAS. The most recent recorded depth to the water table is approximately 709 ft bgs (USGS/DOE, 2006).

\subsubsection{Alkali Flat Furnace Creek Ranch Subbasin}

Corrective Action Sites 18-01-01 and 18-99-03 are located within the Alkali Flat Furnace Creek Ranch Subbasin. The groundwater in this area primarily flows through volcanic aquifers in a south-southwest direction towards the Death Valley and Ash Meadows discharge areas. Beneath the site lies the vitric-tuff aquifer and the welded-tuff aquifer, which are bedded tuffs and welded ash flow tuffs, respectively (DOE/NV, 1997a).

The precipitation recharge of the Alkali Flat Furnace Creek Ranch Subbasin occurs along its northern boundary at Kawich Range and Reveille Range, and along the northeastern boundary at Belted Range, Rainier Mesa, and Shoshone Mountain. Within the subbasin, recharge occurs throughout eastern Pahute Mesa and in the southern portion of the Kawich Range. Some recharge may also occur from precipitation on Timber Mountain and the Funeral Mountains. The average annual precipitation at station Little Feller 2 is 7.99 in. (ARL/SORD, 2006).

Well UE-18t is located approximately $1.5 \mathrm{mi}$ northwest of the CASs. The most recent recorded depth to the water table is approximately $913 \mathrm{ft}$ bgs (USGS/DOE, 2006).

\subsection{Operational History}

The following subsections provide a description of the use and history of each CAS in CAU 166 that may have resulted in potential releases to the environment. The CAS-specific summaries are designed to describe the current definition of each CAS and illustrate all significant, known activities.

\subsubsection{Corrective Action Sites 02-42-01, Cond. Release Storage Yd - North; 02-42-02, Cond. Release Storage Yd - South; 02-99-10, D-38 Storage Area}

These CASs consist of the locations at which spills or leaks of chemical and/or radioactive material may have occurred while equipment and miscellaneous items were stored in the yards. Additionally, drums containing depleted uranium were stored at CAS 02-99-10. These CASs are located in the 
former Area 2 Camp. The camp supported the Lawrence Livermore National Laboratory (LLNL) drilling and construction activities in the Yucca Flat area. According to documentation, the Area 2 Camp and presumably the storage yards, were operational from the early 1960s through the mid 1990s. The surrounding buildings have since been demolished and/or removed. Miscellaneous debris such as wood, wire, metal, and glass remains at the site. Figures A.2-2 through A.2-4 are site sketches of the storage yards.

\subsubsection{Corrective Action Site 03-42-01, Conditional Release Storage Yard}

This CAS consists of the locations at which spills or leaks of chemical and/or radioactive material may have occurred while equipment, portable buildings, tanks, and miscellaneous items were stored in the yard. This CAS is located in the former Area 3 Camp. The camp supported the Los Alamos National Laboratory (LANL) drilling and construction activities in the Yucca Flat area. According to documentation, the Area 3 Camp and presumably the storage yard, were operational from the early 1960s through 1993. The majority of the surrounding buildings have since been demolished and/or removed. Figures A.2-5 and A.2-6 are site sketches of the storage yard.

\subsubsection{Corrective Action Site 05-19-02, Contaminated Soil and Drum}

This CAS consists of the locations at which spills or leaks of chemical and/or radioactive material may have occurred while miscellaneous test related items and vehicles were stored in the yard. Additionally, the CAS includes spills or leaks from drums previously stored adjacent to the yard and the single drum still located in an adjacent wash. This CAS is associated with Operation Ranger, a series of atmospheric nuclear tests that took place in 1951. The vehicles that remain in the storage yard were placed there to allow induced activity to decay. It is unknown if the drums are associated with the testing. Figure A.2-10 is a site sketch of the storage yard and drum.

\subsubsection{Corrective Action Sites 18-01-01, Aboveground Storage Tank, and 18-99-03, Wax Piles/Oil Stain}

This CAS consists of potential releases from the metal containers and wax piles located at the site. These containers and wax piles are believed to be associated with the Little Feller II test that took place in 1962. It is speculated that the metal containers and wax piles/hardened residue was a part of 
the neutron flux experiments that took place as part of the testing. Figures A.2-11, A.2-12, A.2-14, and A.2-15 are site sketches of the CASs.

\subsection{Waste Inventory}

Available documentation, interviews with former site employees, process knowledge, and general historical NTS practices were used to identify wastes that may be present. Historical information and site visits indicate that the sites contain wastes such as drilling equipment, portable buildings, tanks, piping, metal containers, a drum, and other miscellaneous debris such as wood, wire, metal, cables, and broken glass.

\subsubsection{Corrective Action Sites 02-42-01, Cond. Release Storage Yd - North; 02-42-02 Cond. Release Storage Yd - South; 02-99-10, D-38 Storage Area}

Solid waste items identified at CASs 02-42-01, 02-42-02, and 02-99-10 may include a small amount of surface debris (e.g., wood, wire, metal, cables, and broken glass). Potential waste types may include sanitary waste, hydrocarbon waste, Resource Conservation and Recovery Act (RCRA) hazardous waste, radioactive waste, and mixed waste. The waste types may be comprised of debris, IDW, decontamination liquids, and soils.

\subsubsection{Corrective Action Site 03-42-01, Conditional Release Storage Yard}

Solid waste items identified at CAS 03-42-01 may include drilling equipment, portable buildings, tanks, piping, and miscellaneous metal debris and may be managed, as appropriate, as part of the CAI. Potential waste types may include sanitary waste, hydrocarbon waste, RCRA hazardous waste, radioactive waste, and mixed waste. The waste types may be comprised of debris, IDW, decontamination liquids, and soils.

\subsubsection{Corrective Action Site 05-19-02, Contaminated Soil and Drum}

Solid waste items identified at CAS 05-19-02 may include a drum. Potential waste types may include sanitary waste, hydrocarbon waste, RCRA hazardous waste, radioactive waste, and mixed waste. The waste types may be comprised of debris, IDW, decontamination liquids, and soils. 


\subsubsection{Corrective Action Sites 18-01-01, Aboveground Storage Tank, and 18-99-03, Wax Piles/Oil Stain}

Solid waste items identified at CASs 18-01-01 and 18-99-03 may include metal containers, a metal box, metal lids scattered about the site, and the wax piles/hardened residue. Potential waste types may include sanitary waste, hydrocarbon waste, RCRA hazardous waste, radioactive waste, and mixed waste. The waste types may be comprised of debris, IDW, decontamination liquids, and soils.

\subsection{Release Information}

The following subsections contain CAS-specific descriptions of known or suspected releases. If a release occurred, the native soil interface below and adjacent to any locations that contained stored materials is the most likely location for soil contamination. Any contaminants migrating from the seven CASs, regardless of physical or chemical characteristics, are expected to be in soil adjacent to the sites lateral and vertical native-soil interfaces. Contamination, if present, is expected to be contiguous to the release points at all sites. Concentrations are expected to decrease with horizontal and vertical distance from the source.

If migration of contamination at any of the seven CASs in CAU 166 were to have occurred, the most reasonable transport mechanism would be erosion/mass transport by surface runoff of precipitation. Flowing water has the potential to carry both dissolved and suspended contaminants. Washes, such as the one that lies within the footprint of CAS 05-19-02, can carry runoff water and possibly contaminants away from the original site of release.

Potentially affected media for all CASs include surface and shallow subsurface soil. Corrective Action Site 03-42-01 also contains associated debris and equipment within a posted radioactive material area (RMA) that may be impacted by contaminants and that could have been released to environmental media within the yard. Exposure routes to site workers include ingestion, inhalation, and/or dermal contact (absorption) from disturbance of contaminated soils, debris, and/or structures. Site workers may also be exposed to radiation by performing activities in proximity to radiologically contaminated materials.

At CASs 18-01-01 and 18-99-03, surface soils have likely been impacted by contamination associated with Little Feller II testing. This contamination is not associated with a release from 
CAU 166 and will not be included in the subsequent evaluation of the site, as it will be addressed by Soils Project CAU 107, CAS 18-45-03.

\subsubsection{Corrective Action Sites 02-42-01, Cond. Release Storage Yd - North; 02-42-02, Cond. Release Storage Yd - South; 02-99-10, D-38 Storage Area}

Equipment, materials, or operations associated with these CASs may have resulted in a release of contamination to the soil in the storage yards. It is reasonable to conclude that radiological contaminants may have been released to the soil since the majority of the equipment stored in the yards were associated with testing at the NTS. All three CASs were formerly posted with radiological signs. Hazardous consituents could be present due to traffic in the yards and other miscellaneous items stored in the yards. If a release occurred, contaminants are expected to have been limited in volume and are expected to be located in the soil within the storage yards.

\subsubsection{Corrective Action Site 03-42-01, Conditional Release Storage Yard}

Equipment, materials, or operations associated with this CAS may have resulted in a release of contamination to the soil in the storage yard. It is reasonable to conclude that radiological contaminants may have been released to the soil since the majority of the equipment stored in the yard was associated with testing at the NTS. A portion of this CAS is posted as Radioactive Material. Hazardous consituents could be present due to traffic in the yards and other miscellanous items that were stored in the yard. If a release occurred, contaminants are expected to have been limited in volume and located in the soil within the storage yard.

\subsubsection{Corrective Action Site 05-19-02, Contaminated Soil and Drum}

Materials associated with this CAS may have resulted in a release of contamination to the soil in the storage yard and in select adjacent locations. It is reasonable to conclude that radiological contaminants may have been released to the soil because the material stored in the yard was associated with a series of atmospheric nuclear tests. Hazardous consituents could be present because vehicles were stored in the yard along with other miscellaneous items. Additionally, numerous drums were stored along the side of the yard. One drum remains in the wash while drum remnants are present in a separate location outside of the storage yard boundary. The contents of the former drums is unknown. The drum that is still present is open and sand is visible inside the drum. Additional 
contents are unknown, if any. If a release occurred, contaminants are expected to be limited in volume and located in the soil within the storage yard, in the vicinity of the former drum storage area, and adjacent to the drum in the wash and drum remnants location.

\subsubsection{Corrective Action Sites 18-01-01, Aboveground Storage Tank, and 18-99-03, Wax Piles/Oil Stain}

Operations associated with these CASs may have resulted in a release of contamination to the soil where the metal containers and wax piles/hardened residue are located. It is reasonable to conclude that radiological contaminants may have been released to the soil since the metal containers and wax piles/hardened residue are associated with the Little Feller II testing. A portion of CAS 18-99-03 and all of CAS 18-01-01 are located within a contamination area. Hazardous consituents could be present in the wax piles/hardened residue and any other material present within the metal containers. If a release occurred, contaminants are expected to have been limited in volume and located in the soil directly under the metal containers and wax piles/hardened residue.

\subsection{Investigative Background}

The following subsections summarize the investigations conducted at the CAU 166 sites. More detailed discussions of these investigations are found in Appendix A.

\subsubsection{Corrective Action Sites 02-42-01, Cond. Release Storage Yd - North; 02-42-02, Cond. Release Storage Yd - South; 02-99-10, D-38 Storage Area}

Previous investigations at these CASs include site visits and radiological surveys. During the site visits, it was determined that there is no visible staining in these yards and that the majority of equipment and materials stored at these yards has since been removed. In November 2004 and March 2006, radiological surveys were performed at CASs 02-42-01, 02-42-02 and 02-99-10. The surveys indicated that the gamma radiation was at or near background at all CASs (Nicosia, 2004 and 2006).

\subsubsection{Corrective Action Site 03-42-01, Conditional Release Storage Yard}

Previous investigations at these CASs include site visits, radiological surveys, and sampling at a co-located CAS. During the site visits, it was determined that there is no visible staining in the 
unfenced portion of the yard and that the majority of equipment and materials stored in this area has since been removed. There is one pile of drilling equipment and miscellaneous items still remaining; the rest of that portion of the yard is empty. The fenced and posted portion of the yard still contains quite a bit of equipment, tanks, piping, portable buildings and other miscellaneous items. There are numerous visible stains present in this portion of the yard.

In February 2004, a radiological survey was performed by SNJV of CAU 145, CAS 03-20-08. This CAS is located within the posted and fenced portion of CAS 03-42-01. The survey covered the majority of this portion of the yard. No removable contamination was encountered and the gamma radiation for surficial soil was very near background (Alderson, 2004). In March 2006, a radiological survey was performed in the remainder of the yard. It was determined that the site poses no risk to individuals from residual radiological contamination for non-intrusive activities (Nicosia, 2006).

During the CAI of CAU 145, CAS 03-20-08, initiated in August 2005, diesel-range organics (DRO) was detected at a level of 500 milligrams per kilogram $(\mathrm{mg} / \mathrm{kg})$ in a sample taken adjacent to the CAS 03-20-08 former catch basin within the fenced storage yard. The sample was taken at an interval of 5 to $6 \mathrm{ft}$ bgs, approximately $5 \mathrm{ft}$ west of the catch basin (25 ft from its center). It was determined that this contaminant is most likely a result of activities that took place in the storage yard in CAS 03-42-01.

\subsubsection{Corrective Action Site 05-19-02, Contaminated Soil and Drum}

Previous investigations at this CAS includes site visits and a radiological survey. During the site visits, it was determined that there is no visible staining in the yard and that the majority of equipment and materials originally stored at this yard has since been removed. The only remaining items are three vehicles and steel debris. Additionally, a drum is present in the wash adjacent to the yard and drum remnants were found located near the storage yard. There is no evidence of staining in these locations or in the former drum location adjacent to the storage yard. In March 2006, a radiological survey was completed in the storage yard and adjacent areas. It was determined that the site poses no risk to individuals from residual radiological contamination for non-intrusive activities (Nicosia, 2006). 


\subsubsection{Corrective Action Sites 18-01-01, Aboveground Storage Tank, and 18-99-03, Wax Piles/Oil Stain}

Previous investigations at this CAS includes site visits and a radiological survey. During the site visits, it was determined that there is visible staining in the areas of the wax piles. The staining consists of hardened residue surrounding the piles of wax, both inside and outside of the contamination area. In March 2006, a radiological survey was completed at these sites. It was determined that some areas within the posted contamination area had elevated gamma radiation (Nicosia, 2006).

\subsubsection{National Environmental Policy Act}

The Final Environmental Impact Statement for the Nevada Test Site and Off-Site Locations in the State of Nevada (DOE/NV, 1996) includes site investigation activities such as those proposed for CAU 166.

In accordance with the NNSA/NSO National Environmental Policy Act (NEPA) Compliance Program, a NEPA checklist will be completed before beginning site investigation activities at CAU 166. This checklist requires NNSA/NSO project personnel to evaluate their proposed project activities against a list of potential impacts that include, but are not limited to: air quality, chemical use, waste generation, noise level, and land use. Completion of the checklist results in a determination of the appropriate level of NEPA documentation by the NNSA/NSO NEPA Compliance Officer. This will be accomplished before mobilization for the field investigation. 


\subsection{Objectives}

This section presents an overview of the DQOs for CAU 166 and formulation of the CSM. Also presented is a summary listing of the contaminants reasonably suspected to be present at each CAS, the COPCs, the preliminary action levels (PALs) for the investigation, and the process used to establish FALs. Additional details and figures depicting the CSM are located in Appendix A.

\subsection{Conceptual Site Model}

The CSM describes the most probable scenario for current conditions at each site and defines the assumptions that are the basis for identifying the future land use, contaminant sources, release mechanisms, migration pathways, exposure points, and exposure routes. The CSM is also used to support appropriate sampling strategies and data collection methods. The CSM has been developed for CAU 166 using information from the physical setting, potential contaminant sources, release information, historical background information, knowledge from similar sites, and physical and chemical properties of the potentially affected media and COPCs. Figure 3-1 depicts a tabular representation of the conceptual pathways to receptors from CAU 166 sources. Figure 3-2 depicts a graphical representation of the CSM. If evidence of contamination that is not consistent with the presented CSM is identified during investigation activities, the situation will be reviewed, the CSM revised, the DQOs re-assessed, and a recommendation made as to how best to proceed. In such cases, decision makers listed in Section A.3.1 will be notified and given the opportunity to comment on and/or concur with the recommendation.

The following sections discuss future land use and the identification of exposure pathways (i.e., combination of source, release, migration, exposure point, and receptor exposure route) for the CAU.

\subsubsection{Land Use and Exposure Scenarios}

Corrective Action Sites 02-42-01, 02-42-02, 02-99-10, and 03-42-01 are located in the land-use zone described as the "Nuclear and High Explosives Test Zone.” This area is designated for additional underground nuclear weapons tests and high-explosives test. This zone includes compatible defense and non-defense research, development, and testing activities (DOE/NV, 1998). 


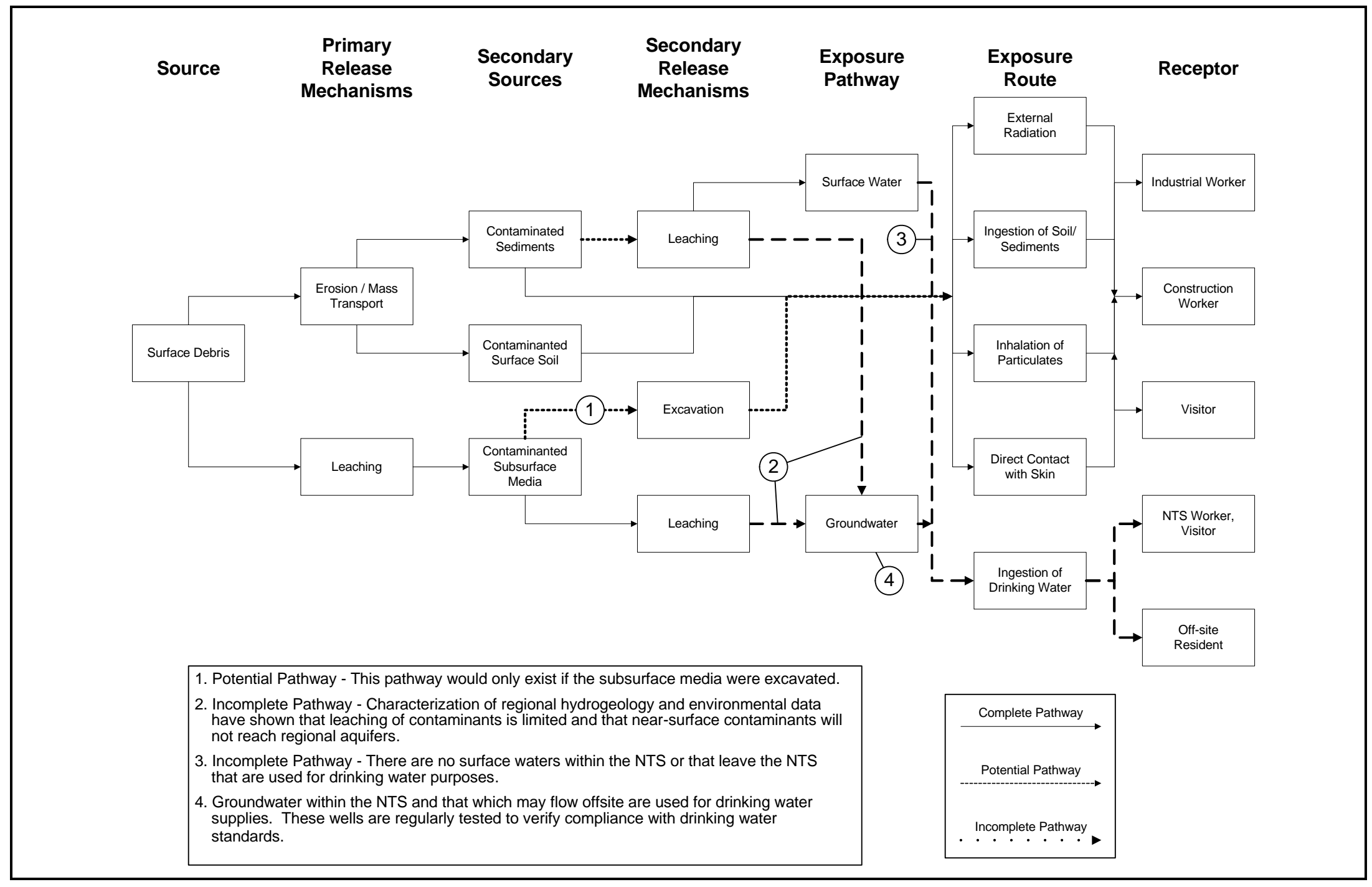

Figure 3-1

Conceptual Site Model Diagram

\section{Uncontrolled When Printed}




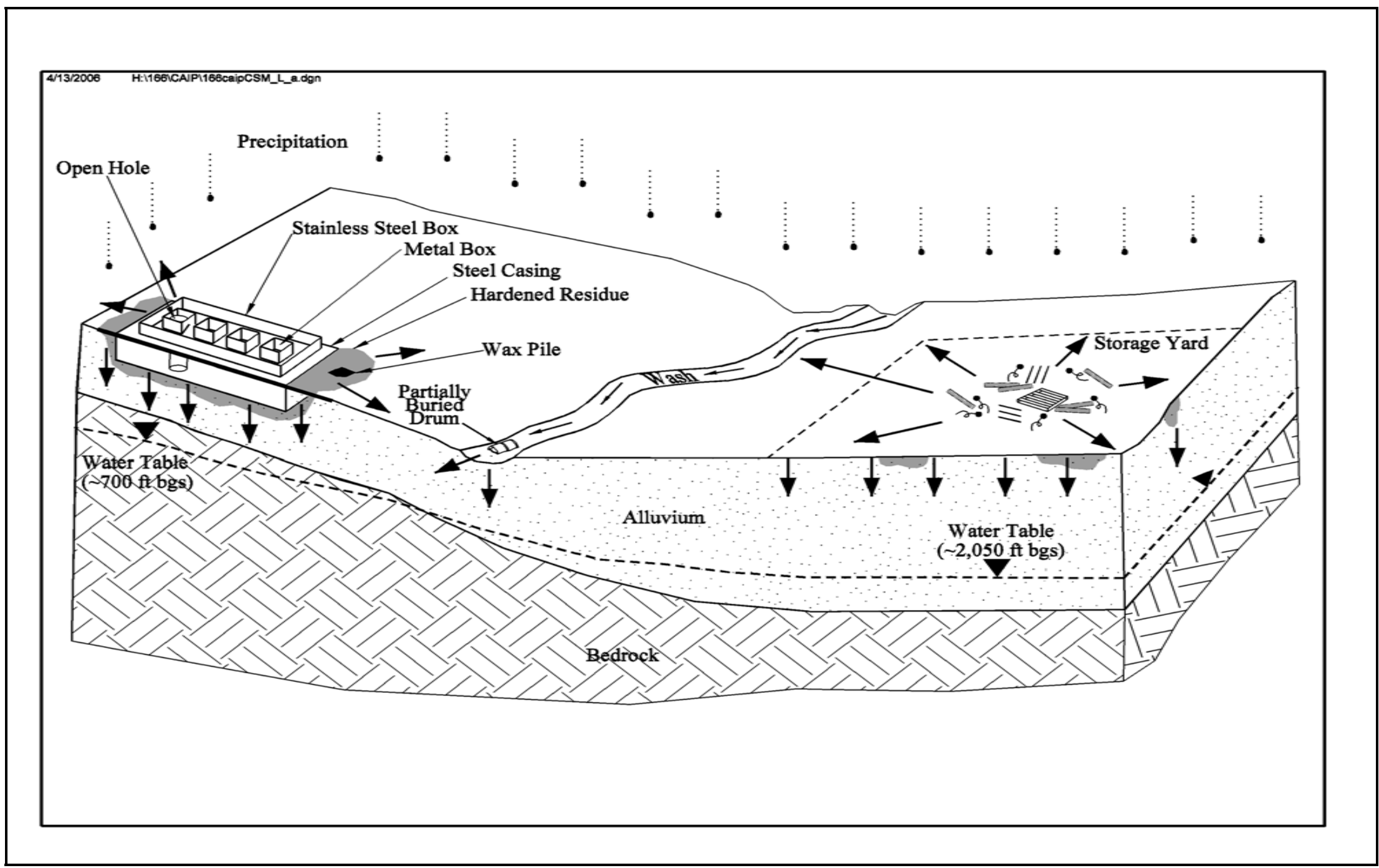

Figure 3-2

Corrective Action Unit 166 Conceptual Site Model 
Corrective Action Sites 05-19-02, 18-01-01, and 18-99-03 are located in the land-use zone described as "Reserved (within the NTS)." This area includes land and facilities that provide widespread flexible support for diverse short-term testing and experimentation. The reserved zone is also used for short-duration exercises and training such as nuclear emergency response, Federal Radiological Monitoring and Assessment Center training, and DoD land-navigation exercises and training (DOE/NV, 1998).

All land-use zones where the CAU 166 CASs are located dictate future land uses will be limited to non-residential (i.e., industrial) activities.

Based on current and future land uses, CAU 166 CASs meet the criteria for the "Occasional Use Area." This exposure scenario assumes exposure to industrial workers who are not assigned to the area as a regular worksite but may occasionally use the site for intermittent or short-term activities. In this scenario, a site worker is assumed to be on the site for the equivalent of up to 8 hours per day, 10 days per year, for five years.

\subsubsection{Contaminant Sources}

The contamination sources for the CAU 166 CSM are:

- Drilling equipment, portable buildings, tanks, piping, vehicles, drums, and miscellaneous debris that could have released fluids or transferred radioactive material to the storage yards.

- Metal containers and wax piles/hardened residue that could have released contaminants to the environment.

\subsubsection{Release Mechanisms}

Release mechanisms for the CSM are spills and leaks onto surface soils from equipment or stored materials. Materials stored in containers may have leaked or have been spilled. Contamination from the various types of stored materials may have been transferred to the underlying soil.

\subsubsection{Migration Pathways}

The migration pathways and transport mechanism that could potentially move the contaminants through the various media are presented in the CSM (Figures 3-1 and 3-2). The pathways include air, 
surface water, and groundwater, and are the routes through which possible contamination could migrate from the site(s) to locations where a receptor might receive an exposure.

Movement of liquid or solid contaminants away from the point of release at the CAU 166 CASs is mainly related to the movement of water, either by percolation into subsurface media or overland migration with flowing water. Infiltration and percolation of precipitation serves as the major driving force for downward migration of contaminants. However, due to high potential evapotranspiration (annual potential evapotranspiration at the Area 3 Radiological Waste Management Site has been estimated at 62.6 in. (Shott et al., 1997) and limited precipitation for this region (6 to 12 in. per year [Winograd and Thordarson, 1975]), percolation of infiltrated precipitation at the NTS does not provide a significant mechanism for vertical migration of contaminants to groundwater (DOE/NV, 1992).

If migration of contaminants at the seven CASs in CAU 166 were to have occurred, the dominant transport mechanism would be erosion/mass transport by surface runoff of precipitation (Figure 3-1). Flowing water has the potential to carry both dissolved and suspended contaminants. The migration pathway through which contamination from the CASs in CAU 166 might migrate is surface water (Figure 3-1). Washes and gullies, such as the wash that is located within the footprint of CAS 05-19-02, can carry runoff water and possible contaminants away from the original site of release. Other land features such as excavations, trenches, craters, and holes could receive runoff water and possible contaminants (Figure 3-2). This transport mechanism is depicted in the CSM as the means for contamination to move from the point of release to other areas, impacting sediments and surface soils that become potential exposure points, including areas outside the CAS boundaries. Airborne migration of contaminants is considered a minor transport mechanism for CAU 166.

Migration is influenced by physical and chemical characteristics of the contaminants and media. Contaminant characteristics include, but are not limited to: solubility, density, and adsorption potential. Media characteristics include permeability, porosity, water saturation, sorting, chemical composition, and organic content. In general, contaminants with low solubility, high affinity for media, and high density can be expected to be found relatively close to release points. Contaminants with high solubility, low affinity for media, and low density can be expected to be found further from 
release points. These factors affect the migration pathways and potential exposure points for the contaminants in the various media under consideration.

\subsubsection{Exposure Points}

Exposure points for the CSM are expected to be areas of surface contamination where visitors and site workers will come in contact with soil surface. Subsurface exposure points may also exist if construction workers come in contact with contaminated media during excavation activities. Site workers may also be exposed to radiological contamination by performing activities in proximity to radiologically contaminated materials.

\subsubsection{Exposure Routes}

Exposure routes to site workers include exposure to radiation fields, ingestion, inhalation, and/or dermal contact (absorption) from disturbance of, or direct contact with, contaminated media.

\subsubsection{Additional Information}

Information concerning topography, geology, climatic conditions, hydrogeology, floodplains, and infrastructure at the CAU 166 CASs are available and are presented in Section 2.1 as they pertain to the investigation. This information has been addressed in the CSM and will be considered during the evaluation of corrective action alternatives, as applicable.

\subsection{Contaminants of Potential Concern}

The COPCs for CAU 166 are defined as the list of constituents represented by the analytical methods identified in Table 3-1 for Decision I environmental samples taken at each of the CASs. The constituents reported for each analytical method are listed in Table 3-2. The list of COPCs is intended to encompass all of the contaminants that could potentially be present at each CAS. These COPCs were identified during the planning process through the review of site history, process knowledge, personal interviews, past investigation efforts (where available), and inferred activities associated with the CASs. Contaminants detected at other similar or other NTS sites were also included in the COPC list to reduce the uncertainty about potential contamination at the CASs because complete information regarding activities performed at the CAU 166 sites is not available. 
Table 3-1

\begin{tabular}{|c|c|c|c|c|c|}
\hline Analyses & 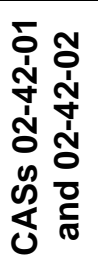 & 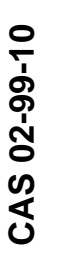 & 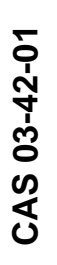 & 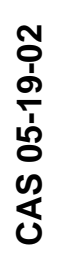 & 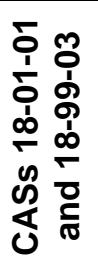 \\
\hline \multicolumn{6}{|c|}{ Organic Contaminants of Potential Concern (COPCs) } \\
\hline Total Petroleum Hydrocarbons (Diesel-Range Organics) & $\mathrm{X}$ & $\mathrm{x}$ & $\mathrm{x}$ & $\mathrm{X}$ & $\mathrm{x}$ \\
\hline Total Petroleum Hydrocarbons (Gasoline-Range Organics) & $\mathrm{X}$ & $\mathrm{x}$ & $\mathrm{x}$ & $\mathrm{X}$ & $\mathrm{X}$ \\
\hline Polychlorinated Biphenyls & $\mathrm{x}$ & $\mathrm{x}$ & $\mathrm{x}$ & $\mathrm{x}$ & $\mathrm{x}$ \\
\hline Semivolatile Organic Compounds & $\mathrm{x}$ & $\mathrm{x}$ & $\mathrm{X}$ & $\mathrm{x}$ & $\mathrm{x}$ \\
\hline Volatile Organic Compounds & $\mathrm{x}$ & $\mathrm{x}$ & $\mathrm{x}$ & $x$ & $\mathrm{x}$ \\
\hline Pesticides & $\mathrm{x}$ & $\mathrm{x}$ & $x$ & -- & -- \\
\hline \multicolumn{6}{|c|}{ Inorganic COPCs } \\
\hline Resource Conservation and Recovery Act Metals & $x$ & $x$ & $x$ & $x$ & $\mathrm{x}$ \\
\hline \multicolumn{6}{|c|}{ Radionuclide COPCs } \\
\hline Gamma Spectroscopy $^{\mathrm{b}}$ & $x$ & $x$ & $x$ & $x$ & $x$ \\
\hline Isotopic Uranium ${ }^{b}$ & -- & $x$ & -- & -- & $x$ \\
\hline Isotopic Plutonium & -- & -- & -- & -- & $x$ \\
\hline Strontium-90 & -- & -- & -- & -- & $\mathrm{X}$ \\
\hline
\end{tabular}

$X=$ Required analytical method

$--=$ Analytical method not required

${ }^{\text {aT }}$ The COPCs are the analytes reported from the analytical methods listed (Table 3-2).

${ }^{b}$ Results of gamma analysis will be used to determine whether further radioanalytical analysis is warranted.

During the review of site history documentation, process knowledge information, personal interviews, past investigation efforts (where available), and inferred activities associated with the CASs, some of the COPCs were identified as targeted contaminants at specific CASs. Targeted contaminants are those COPCs for which evidence in the available site and process information suggests that they may be reasonably suspected to be present at a given CAS. The targeted contaminants are required to meet a more stringent completeness criteria than other COPCs thus providing greater protection against a decision error (see Sections A.1.0 through A.7.0). Targeted contaminants for each CAU 166 CAS are identified in Table 3-3. 
Table 3-2

\section{Constituents Reported by Analytical Methods}

(Page 1 of 2)

\begin{tabular}{|c|c|c|c|c|c|c|c|}
\hline VOCs & SVOCs & TPH & PCBs & Metals & Pesticides & $\begin{array}{c}\text { Isotopic } \\
\text { Radionuclides }\end{array}$ & $\begin{array}{c}\text { Gamma- } \\
\text { Emitting } \\
\text { Radionuclides }\end{array}$ \\
\hline $\begin{array}{l}\text { 1,1,1-Trichloroethane } \\
\text { 1,1,1,2-Tetrachloroethane } \\
\text { 1,1,2,2-Tetrachloroethane } \\
\text { 1,1,2-Trichloroethane } \\
\text { 1,1-Dichloroethane } \\
\text { 1,1-Dichloroethene } \\
\text { cis-1,2-Dichloroethene } \\
\text { 1,2-Dichloroethane } \\
\text { 1,2-Dichloropropane } \\
\text { 1,2,4-Trichlorobenzene } \\
\text { 1,2,4-Trimethylbenzene } \\
\text { 1,2-Dibromo-3-chloropropane } \\
\text { 1,3,5-Trimethylbenzene } \\
\text { 1,4-Dioxane } \\
\text { 2-Butanone } \\
\text { 2-Chlorotoluene } \\
\text { 2-Hexanone } \\
\text { 4-Methyl-2-pentanone } \\
\text { Acetone } \\
\text { Acetonitrile } \\
\text { Allyl chloride } \\
\text { Benzene } \\
\text { Bromodichloromethane } \\
\text { Bromoform } \\
\text { Bromomethane } \\
\text { Carbon disulfide } \\
\text { Carbon tetrachloride } \\
\text { Chlorobenzene } \\
\text { Chloroethane } \\
\text { Chloroform } \\
\text { Chloromethane } \\
\text { Chloroprene } \\
\text { Dibromochloromethane } \\
\text { Dichlorodifluoromethane } \\
\text { Ethyl methacrylate } \\
\text { Ethylbenzene }\end{array}$ & $\begin{array}{l}\text { 2,3,4,6-Tetrachlorophenol } \\
\text { 2,4-Dimethylphenol } \\
\text { 2,4-Dinitrotoluene } \\
\text { 2,4,5-Trichlorophenol } \\
\text { 2,4,6-Trichlorophenol } \\
\text { 2-Chlorophenol } \\
\text { 2-Methylnaphthalene } \\
\text { 2-Methylphenol } \\
\text { 2-Nitrophenol } \\
\text { 3-Methylphenol } \\
\text { 4-Chloroaniline } \\
\text { 4-Methylphenol } \\
\text { 4-Nitrophenol } \\
\text { Acenaphthene } \\
\text { Acenaphthylene } \\
\text { Aniline } \\
\text { Anthracene } \\
\text { Benzo(a)anthracene } \\
\text { Benzo(a)pyrene } \\
\text { Benzo(b)fluoranthene } \\
\text { Benzo(g,h,i)perylene } \\
\text { Benzo(k)fluoranthene } \\
\text { Benzoic Acid } \\
\text { Benzyl Alcohol } \\
\text { Bis(2-ethylhexyl) phthalate } \\
\text { Butyl benzyl phthalate } \\
\text { Carbazole } \\
\text { Chrysene } \\
\text { Dibenzo(a,h)anthracene } \\
\text { Dibenzofuran } \\
\text { Diethyl Phthalate } \\
\text { Dimethyl Phthalate } \\
\text { Di-n-butyl Phthalate } \\
\text { Di-n-octyl Phthalate } \\
\text { Fluoranthene } \\
\text { Fluorene }\end{array}$ & $\begin{array}{l}\text { TPH } \\
\text { (Diesel-Range } \\
\text { Organics and } \\
\text { Gasoline-Range } \\
\text { Organics) }\end{array}$ & $\begin{array}{l}\text { Aroclor } 1016 \\
\text { Aroclor } 1221 \\
\text { Aroclor } 1232 \\
\text { Aroclor } 1242 \\
\text { Aroclor } 1248 \\
\text { Aroclor } 1254 \\
\text { Aroclor } 1260 \\
\text { Aroclor } 1268\end{array}$ & $\begin{array}{l}\text { Arsenic } \\
\text { Barium } \\
\text { Beryllium } \\
\text { Cadmium } \\
\text { Chromium } \\
\text { Lead } \\
\text { Mercury } \\
\text { Selenium } \\
\text { Silver }\end{array}$ & $\begin{array}{l}\text { 4,4'-DDD } \\
4,4^{\prime}-\mathrm{DDE} \\
4,4^{\prime}-\mathrm{DDT} \\
\text { Aldrin } \\
\text { Alpha-BHC } \\
\text { Alpha-Chlordane } \\
\text { Beta-BHC } \\
\text { Chlordane (Technical) } \\
\text { Delta-BHC } \\
\text { Dieldrin } \\
\text { Endosulfan I } \\
\text { Endosulfan II } \\
\text { Endosulfan Sulfate } \\
\text { Endrin } \\
\text { Endrin Aldehyde } \\
\text { Edrin Ketone } \\
\text { Gamma-BHC } \\
\text { Gamma-Chlordane } \\
\text { Heptachlor } \\
\text { Heptachlor Epoxide } \\
\text { Methoxychlor } \\
\text { Toxaphene }\end{array}$ & $\begin{array}{l}\text { Plutonium-238 } \\
\text { Plutonium-239/240 } \\
\text { Strontium-90 } \\
\text { Uranium-234 } \\
\text { Uranium-235 } \\
\text { Uranium-238 }\end{array}$ & $\begin{array}{l}\text { Actinium-228 } \\
\text { Aluminum-26 } \\
\text { Americium-241 } \\
\text { Antimony-125 } \\
\text { Beryllium-7 } \\
\text { Bismuth-212 } \\
\text { Bismuth-214 } \\
\text { Cesium-134 } \\
\text { Cesium-137 } \\
\text { Cobalt-58 } \\
\text { Cobalt-60 } \\
\text { Curium-243 } \\
\text { Europium-152 } \\
\text { Europium-154 } \\
\text { Europium-155 } \\
\text { Lead-212 } \\
\text { Lead-214 } \\
\text { Niobium-94 } \\
\text { Potassium-40 } \\
\text { Thallium-208 } \\
\text { Thorium-227 } \\
\text { Thorium-234 } \\
\text { Uranium-235 }\end{array}$ \\
\hline
\end{tabular}


Table 3-2

Constituents Reported by Analytical Methods

(Page 2 of 2)

\begin{tabular}{|c|c|c|c|c|c|c|c|}
\hline VOCs & SVOCs & TPH & PCBs & Metals & Pesticides & $\begin{array}{c}\text { Isotopic } \\
\text { Radionuclides }\end{array}$ & $\begin{array}{c}\text { Gamma- } \\
\text { Emitting } \\
\text { Radionuclides }\end{array}$ \\
\hline $\begin{array}{l}\text { Isobutyl alcohol } \\
\text { Isopropylbenzene } \\
\text { m-Dichlorobenzene }(1,3) \\
\text { Methacrylonitrile } \\
\text { Methyl methacrylate } \\
\text { Methylene chloride } \\
\text { N-Butylbenzene } \\
\text { N-Propylbenzene } \\
\text { o-Dichlorobenzene }(1,2) \\
\text { p-Dichlorobenzene }(1,4) \\
\text { p-isopropyltoluene } \\
\text { sec-Butylbenzene } \\
\text { Styrene } \\
\text { tert-Butylbenzene } \\
\text { Tetrachloroethene } \\
\text { Toluene } \\
\text { Total Xylenes } \\
\text { Trichloroethene } \\
\text { Trichlorofluoromethane } \\
\text { Vinyl acetate } \\
\text { Vinyl chloride }\end{array}$ & $\begin{array}{l}\text { Hexachlorobenzene } \\
\text { Hexachlorobutadiene } \\
\text { Hexachloroethane } \\
\text { Indeno(1,2,3-cd)pyrene } \\
\text { Naphthalene } \\
\text { Nitrobenzene } \\
\text { N-Nitroso-di-n-propylamine } \\
\text { Pentachlorophenol } \\
\text { Phenanthrene } \\
\text { Phenol } \\
\text { Pyrene } \\
\text { Pyridine }\end{array}$ & & & & & & \\
\hline
\end{tabular}


Table 3-3

Targeted Contaminants for CAU 166

\begin{tabular}{|c|c|c|}
\hline CAS & $\begin{array}{c}\text { Chemical } \\
\text { Targeted Contaminant(s) }\end{array}$ & $\begin{array}{c}\text { Radiological } \\
\text { Targeted Contaminant(s) }\end{array}$ \\
\hline \hline $02-99-10$ & -- & Uranium-238 \\
\hline $03-42-01$ & $\begin{array}{c}\text { Total Petroleum Hydrocarbons- } \\
\text { Diesel-Range Organics }\end{array}$ & - \\
\hline
\end{tabular}

-- = No known targeted contaminant

\subsection{Preliminary Action Levels}

The PALs presented in this section are to be used for site screening purposes. They are not necessarily intended to be used as cleanup action levels or FALs. However, they are useful in screening out contaminants that are not present in sufficient concentrations to warrant further evaluation, therefore, streamlining the consideration of remedial alternatives. The risk-based corrective action (RBCA) process used to establish FALs is described in the Industrial Sites Project Establishment of Final Action Levels (NNSA/NSO, 2006). This process conforms with NAC Section 445A.227 that lists the requirements for sites with soil contamination. For the evaluation of corrective actions, NAC Section 445A.22705 requires the use of American Society for Testing and Materials (ASTM) Method E1739-95 to "conduct an evaluation of the site, based on the risk it poses to public health and the environment, to determine the necessary remediation standards (i.e., FALs) or to establish that corrective action is not necessary” (ASTM, 1995).

This RBCA process, summarized in Figure 3-3 defines three tiers (or levels) of evaluation involving increasingly sophisticated analyses:

- Tier 1 Evaluation - Sample results from source areas (highest concentrations) are compared to action levels based on generic (non-site-specific) conditions (i.e., the PALs established in the CAIP). The FALs may then be established as the Tier 1 action levels or the FALs may be calculated using a Tier 2 evaluation.

- $\quad$ Tier 2 Evaluation - Conducted by calculating Tier 2 Site-Specific Target Levels (SSTLs) using site-specific information as inputs to the same or similar methodology used to calculate Tier 1 action levels. The Tier 2 SSTLs are then compared to individual sample results from reasonable points of exposure (as opposed to the source areas as is done in Tier 1) on a point by point basis. Total TPH concentrations will not be used for risk-based decisions under Tier 2 or Tier 3. Rather, the individual chemicals of concern will be compared to the SSTLs. 


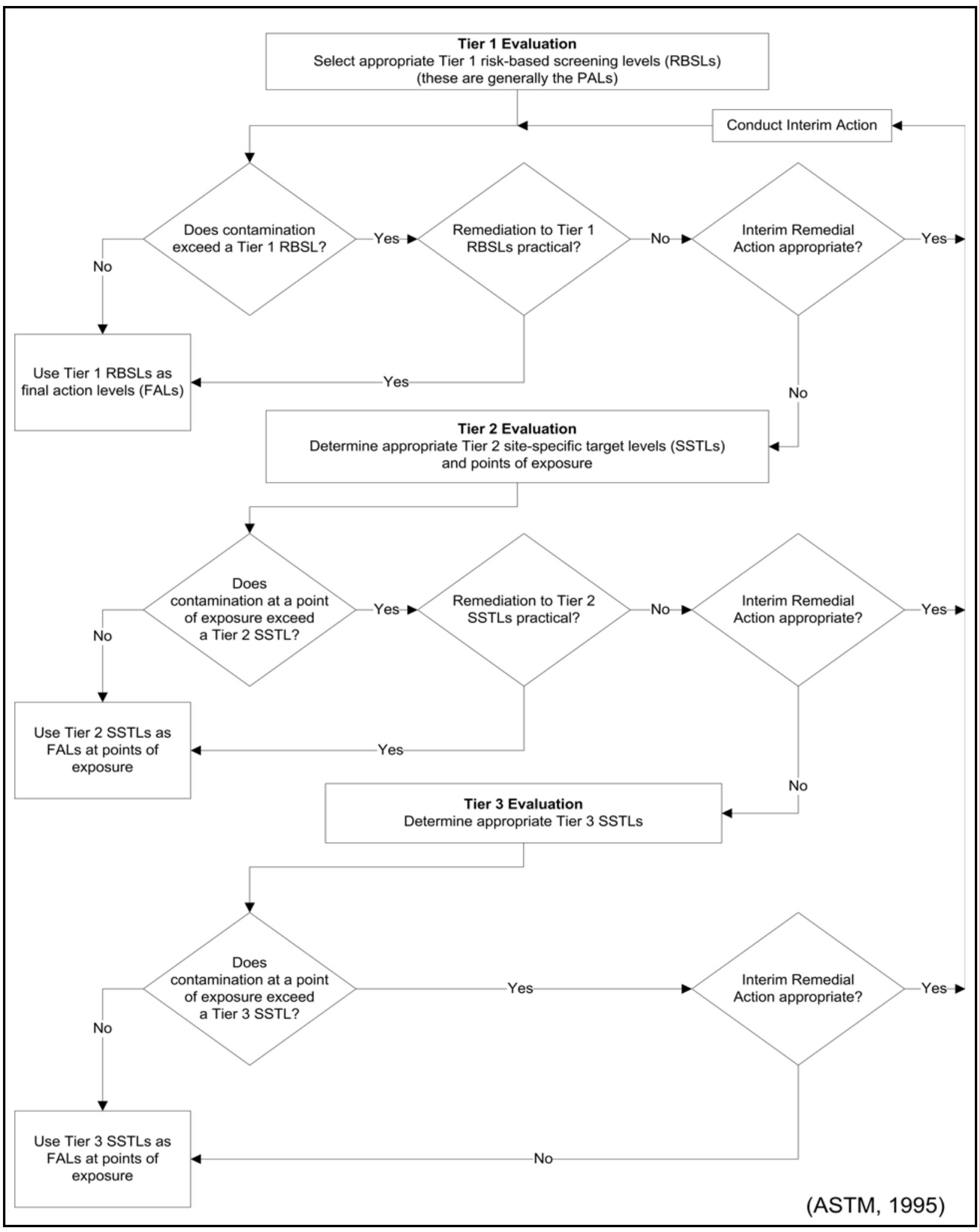

Figure 3-3

Risk-Based Corrective Action Decision Process 
- $\quad$ Tier 3 Evaluation - Conducted by calculating Tier 3 SSTLs on the basis of more sophisticated risk analyses using methodologies described in Method E1739-95 that consider site-, pathway-, and receptor-specific parameters.

This process includes a provision for conducting an interim remedial action if necessary and appropriate. The decision to conduct an interim action may be made at any time during the investigation and at any level (tier) of analysis. Concurrence of the decision makers listed in Section A.3.1 will be obtained before any interim action is implemented. Evaluation of DQO decisions will be based on conditions at the site following completion of any interim actions. Any interim actions conducted will be reported in the investigation report. The FALs (along with the basis for their selection) will be proposed in the investigation report, where they will be compared to laboratory results in the evaluation of potential corrective actions.

\subsubsection{Chemical PALs}

Except as noted herein, the chemical PALs are defined as the U.S. Environmental Protection Agency (EPA) Region 9 Preliminary Remediation Goals (PRGs) for contaminant constituents in industrial soils (EPA, 2004). Background concentrations for RCRA metals and zinc will be used instead of PRGs when natural background concentrations exceed the PRG, as is often the case with arsenic on the NTS. Background is considered the mean plus two standard deviations from the mean for sediment samples collected by the Nevada Bureau of Mines and Geology throughout the Nevada Test and Training Range (formerly the Nellis Air Force Range) (NBMG, 1998; Moore, 1999). For detected chemical COPCs without established PRGs, the protocol used by the EPA Region 9 in establishing PRGs (or similar) will be used to establish PALs. If used, this process will be documented in the investigation report.

\subsubsection{Total Petroleum Hydrocarbon PALs}

The PAL for TPH is 100 parts per million (ppm) as listed in NAC 445A.2272 (NAC, 2005).

\subsubsection{Radionuclide PALs}

The PALs for radiological contaminants (other than tritium) are based on the National Council on Radiation Protection and Measurement (NCRP) Report No. 129 recommended screening limits for construction, commercial, industrial land-use scenarios (NCRP, 1999) using a 25 millirem per year 
(mrem/yr) dose constraint (Murphy, 2004) and the generic guidelines for residual concentration of radionuclides in DOE Order 5400.5 (DOE, 1993). These PALs are based on the construction, commercial, and industrial land-use scenario provided in the guidance and are appropriate for the NTS based on future land use scenarios as presented in Section 3.1.1.

The PAL for tritium is based on the Underground Test Area (UGTA) Project limit of 400,000 picocuries per liter (pCi/L) for discharge of water containing tritium (NNSA/NV, 2002b). The activity of tritium in the soil moisture of soil samples will be reported in units of $\mathrm{pCi} / \mathrm{L}$ for comparison to this PAL.

Solid media such as concrete and/or structures may pose a potential radiological exposure risk to site workers if contaminated. The radiological PAL for solid media will be defined as the unrestricted-release criteria defined in the NV/YMP Radiological Control (RadCon) Manual (NNSA/NSO, 2004).

\subsection{Data Quality Objective Process Discussion}

This section contains a summary of the DQO process that is presented in Appendix A. The DQO process is a strategic planning approach based on the scientific method that is designed to ensure that the data collected will provide sufficient and reliable information to identify, evaluate, and technically defend the recommendation of viable corrective actions (e.g., no further action, clean closure, or closure in place).

The DQO strategy for CAU 166 was developed at a meeting on February 28, 2006. The DQOs were developed to identify data needs, clearly define the intended use of the environmental data, and to design a data collection program that will satisfy these purposes. During the DQO discussions for this CAU, the informational inputs or data needs to resolve problem statements and decision statements were documented. 
The problem statement for CAU 166 is: "Existing information on the nature and extent of potential contamination is insufficient to evaluate and recommend corrective action alternatives for the seven CASs in CAU 166.” To address this question, the resolution of two decisions statements is required:

- Decision I: "Is any COC present in environmental media within the CAS?" If a COC is detected, then Decision II must be resolved. Otherwise, the investigation for that CAS is complete.

- Decision II: "If a COC is present, is sufficient information available to evaluate potential corrective action alternatives?” Sufficient information is defined to include:

- Identification of the volume of media containing any COC bounded by analytical sample results in lateral and vertical directions.

- Characterization of IDW for disposal.

- Determination of potential remediation waste types.

- Evaluation of the feasibility of remediation alternatives (bioassessment if natural attenuation or biodegradation is considered and geotechnical data if construction or evaluation of barriers is considered).

The presence of a COC would require a corrective action. A corrective action also may be necessary if there is a potential for wastes that are present at a site to impose COCs into site environmental media if the wastes were to be released. To evaluate the potential for tank contents to result in the introduction of a COC to the surrounding environmental media, the following conservative assumptions were made:

- The tank containment would fail at some point and the contents would be released to the surrounding media.

- The resulting concentration of contaminants in the surrounding media would be equal to the concentration of contaminants in the tank waste.

- Any liquid contaminant in the septic tanks exceeding the RCRA toxicity characteristic concentration can result in COC introduction to the surrounding media.

Solids within the tank containing a contaminant exceeding an equivalent FAL concentration would be considered to be potential source material and would require a corrective action. Liquids within the 
tank with contaminant concentrations exceeding an equivalent toxicity characteristic action level would be considered potential source material and would require a corrective action.

Decision I samples will be submitted to analytical laboratories for the analyses listed in Table 3-1. Decision II samples will be submitted for the analysis of all unbounded COCs. In addition, samples will be submitted for analyses as needed to support waste management or health and safety decisions.

The data quality indicators (DQIs) of precision, accuracy, representativeness, completeness, comparability, and sensitivity needed to satisfy DQO requirements are discussed in Section 6.2. Laboratory data will be assessed in the investigation report to confirm or refute the CSM and determine whether the DQO data needs were met.

To satisfy the DQI of sensitivity (presented in Section 6.2.8), the analytical methods must be sufficient to detect contamination that is present in the samples at concentrations equal to or less than the corresponding FALs. Analytical methods and minimum detectable concentrations (MDCs) for each CAU 166 COPC are provided in Tables 3-4 and 3-5. The MDC is the lowest concentration of a chemical or radionuclide parameter that can be detected in a sample within an acceptable level of error. Due to changes in analytical methodology and changes in analytical laboratory contracts, information in Tables 3-4 and 3-5 that varies from corresponding information in the QAPP will supersede that information in the Industrial Sites QAPP (NNSA/NV, 2002a). 
Table 3-4

Analytical Requirements for Radionuclides for CAU 166

\begin{tabular}{|c|c|c|c|c|c|c|}
\hline ParameterlAnalyte & Matrix & $\begin{array}{l}\text { Analytical } \\
\text { Method }\end{array}$ & MDC $^{a}$ & $P A L^{b, c}$ & $\begin{array}{c}\text { Laboratory } \\
\text { Precision (RPD) }\end{array}$ & $\begin{array}{c}\text { Percent } \\
\text { Recovery (\%R) }\end{array}$ \\
\hline \multicolumn{7}{|c|}{ Gamma Spectroscopy } \\
\hline Americium-241 & Soil & HASL-300 ${ }^{\dagger}$ & $2.0 \mathrm{pCi} / \mathrm{g}^{\mathrm{e}}$ & $12.7 \mathrm{pCi} / \mathrm{g}$ & \multirow{3}{*}{$\begin{array}{c}\text { RPD } 35 \% \text { (soil) and } \\
20 \% \text { (liquid) } \\
\text { Normalized } \\
\text { Difference } \\
-2<\mathrm{ND}<2^{\mathrm{g}}\end{array}$} & \multirow{3}{*}{$\begin{array}{c}\text { Laboratory } \\
\text { Control Sample } \\
\text { Recovery } 80-120^{\mathrm{h}} \\
\% \mathrm{R}\end{array}$} \\
\hline Cesium-137 & Soil & HASL-300 & $0.5 \mathrm{pCi} / \mathrm{g}^{\mathrm{e}}$ & $12.2 \mathrm{pCi} / \mathrm{g}$ & & \\
\hline Cobalt-60 & Soil & HASL-300 & $0.5 \mathrm{pCi} / \mathrm{g}^{\mathrm{e}}$ & $2.68 \mathrm{pCi} / \mathrm{g}$ & & \\
\hline \multicolumn{7}{|c|}{ Other Radionuclides } \\
\hline Tritium & Soil & Lab specific & $400 \mathrm{pCi} / \mathrm{L}^{\mathrm{d}}$ & $\begin{array}{c}4.0 \mathrm{E}+05 \\
\mathrm{pCi} / \mathrm{L}^{d}\end{array}$ & \multirow{7}{*}{$\begin{array}{l}\text { RPD } 35 \% \text { (soil) and } \\
20 \% \text { (liquid) }\end{array}$} & \multirow{7}{*}{$\begin{array}{c}\text { Laboratory } \\
\text { Control Sample } \\
\text { and Matrix Spike } \\
\text { (tritium only) } \\
\text { Recovery } 80-120^{\text {h }} \\
\% \mathrm{R} \\
\\
\text { Chemical Yield } \\
30-105^{\mathrm{j}} \% \mathrm{R} \\
\text { (not applicable for } \\
\text { tritium) }\end{array}$} \\
\hline Plutonium-238 & Soil & $\begin{array}{c}\text { ASTM } \\
\text { C1001-00k }\end{array}$ & $0.05 \mathrm{pCi} / \mathrm{g}$ & $13.0 \mathrm{pCi} / \mathrm{g}$ & & \\
\hline Plutonium-239/240 & Soil & $\begin{array}{c}\text { ASTM } \\
\text { C1001-00k }\end{array}$ & $0.05 \mathrm{pCi} / \mathrm{g}$ & $12.7 \mathrm{pCi} / \mathrm{g}$ & & \\
\hline Strontium-90 & Soil & HASL $300^{f}$ & $0.5 \mathrm{pCi} / \mathrm{g}$ & $838 \mathrm{pCi} / \mathrm{g}$ & & \\
\hline Uranium-234 & Soil & $\begin{array}{c}\text { ASTM } \\
\text { C1000-02 }\end{array}$ & $0.05 \mathrm{pCi} / \mathrm{g}$ & $143 \mathrm{pCi} / \mathrm{g}$ & & \\
\hline Uranium-235 & Soil & $\begin{array}{c}\text { ASTM } \\
\text { C1000-02 }\end{array}$ & $0.05 \mathrm{pCi} / \mathrm{g}$ & $17.6 \mathrm{pCi} / \mathrm{g}$ & & \\
\hline Uranium-238 & Soil & $\begin{array}{c}\text { ASTM } \\
\text { C1000-02 }\end{array}$ & $0.05 \mathrm{pCi} / \mathrm{g}$ & $105 \mathrm{pCi} / \mathrm{g}$ & & \\
\hline
\end{tabular}

${ }^{a}$ The MDC is the lowest concentration of a radionuclide, if present in a sample, that can be detected with a 95 percent confidence level.

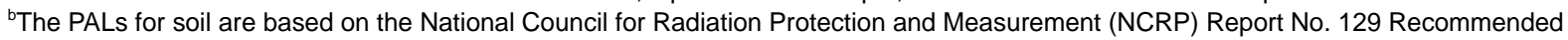
Screening Limits for Contaminated Soil and Review of Factors Relevant to Site-Specific Studies (NCRP, 1999) scaled to $25 \mathrm{mrem} / \mathrm{yr}$ dose and the guidelines for residual concentration of radionuclides in DOE Order 5400.5 (DOE, 1993).

${ }^{\mathrm{C} P A L s}$ for liquids will be developed as needed.

dUnits of $\mathrm{pCi} / \mathrm{L}$ will be reported by the analytical laboratory based on the activity of the tritium in the soil moisture. The PAL for tritium in soil is based on the UGTA Project limit of $400,000 \mathrm{pCi} / \mathrm{L}$ for discharge of water containing tritium to an infiltration basin/area (NNSA/NV, 2002b). ${ }^{e} \mathrm{MDC}$ vary depending on the presence of other gamma-emitting radionuclides in the sample and are relative to the MDC for Cesium-137. ${ }^{\prime} T$ The Procedures Manual of the Environmental Measurements Laboratory, HASL-300 (DOE, 1997).

${ }^{9} \mathrm{ND}$ is not RPD, it is another measure of precision used to evaluate duplicate analyses. The ND is calculated as the difference between two results divided by the square root of the sum of the squares of their total propagated uncertainties. Evaluation of Radiochemical Data Usability (Paar and Porterfield, 1997).

hEPA Contract Laboratory Program Statement of Work for Inorganic Analysis (EPA, 1988a; 1994a; and 1995). 'Standard Test Method for Plutonium in Water (ASTM, 2002b).

jGeneral Radiochemistry and Routine Analytical Services Protocol (GRASP) (EG\&G Rocky Flats, 1991). The chemical yield only applies to plutonium, uranium and strontium.

${ }^{k}$ Standard Test Method for Radiochemical Determination of Plutonium in Soil by Alpha Spectroscopy (ASTM, 2002c).

'Standard Test Method for Isotopic Uranium in Water by Radiochemistry (ASTM, 2002a).

mStandard Test Method for Radiochemical Determination of Uranium Isotopes in Soil by Alpha Spectrometry (ASTM, 2000a).

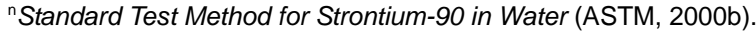

ASTM $=$ American Society for Testing and Materials

$\mathrm{MDC}=$ Minimum detectable concentration

$\mathrm{mrem} / \mathrm{yr}=$ Millirem per year

$\mathrm{ND}=$ Normalized difference

$\mathrm{PAL}=$ Preliminary action level

$\mathrm{pCi} / \mathrm{g}=$ Picocuries per gram

$\mathrm{pCi} / \mathrm{L}=$ Picocuries per liter

$\mathrm{RPD}=$ Relative percent difference

UGTA = Underground Test Area 
Table 3-5

Analytical Requirements for Chemical COPCs for CAU 166*

(Page 1 of 2)

\begin{tabular}{|c|c|c|c|c|c|}
\hline Parameter/Analyte & $\begin{array}{l}\text { Medium } \\
\text { or } \\
\text { Matrix }\end{array}$ & $\begin{array}{l}\text { Analytical } \\
\text { Method }\end{array}$ & $\begin{array}{c}\text { Minimum } \\
\text { Detectable } \\
\text { Concentration } \\
\text { (MDC) }\end{array}$ & $\begin{array}{l}\text { Laboratory } \\
\text { Precision } \\
\text { (RPD) }^{\mathrm{a}}\end{array}$ & $\begin{array}{l}\text { Percent } \\
\text { Recovery } \\
(\% R)^{b}\end{array}$ \\
\hline \multicolumn{6}{|c|}{ ORGANICS } \\
\hline \multirow{2}{*}{$\begin{array}{l}\text { Total Volatile Organic } \\
\text { Compounds }\end{array}$} & Aqueous & \multirow{2}{*}{$8260 B^{c}$} & \multirow{2}{*}{$\begin{array}{c}\text { Parameter-specific } \\
\text { MDCs }^{d}\end{array}$} & \multirow{2}{*}{ Lab-specific $^{e}$} & \multirow{2}{*}{ Lab-specific $^{e}$} \\
\hline & Soil & & & & \\
\hline \multirow{2}{*}{$\begin{array}{c}\text { Total Semivolatile Organic } \\
\text { Compounds }\end{array}$} & Aqueous & \multirow{2}{*}{$8270 C^{c}$} & \multirow{2}{*}{$\begin{array}{c}\text { Parameter-specific } \\
\text { MDCs }^{d}\end{array}$} & \multirow{2}{*}{ Lab-specific $^{\mathrm{e}}$} & \multirow{2}{*}{ Lab-specific $^{e}$} \\
\hline & Soil & & & & \\
\hline \multirow{2}{*}{ Polychlorinated Biphenyls } & Aqueous & \multirow{2}{*}{$8082^{c}$} & \multirow{2}{*}{$\begin{array}{c}\text { Parameter-specific } \\
\text { MDCs }^{d}\end{array}$} & \multirow{2}{*}{ Lab-specific $^{e}$} & \multirow{2}{*}{ Lab-specific ${ }^{e}$} \\
\hline & Soil & & & & \\
\hline \multirow{2}{*}{$\begin{array}{c}\text { Total Petroleum } \\
\text { Hydrocarbons - } \\
\text { Gasoline-Range Organics }\end{array}$} & Aqueous & \multirow{2}{*}{$\begin{array}{l}\text { 8015B } \\
\text { modified }^{c}\end{array}$} & \multirow{2}{*}{$0.5 \mathrm{mg} / \mathrm{kg}^{\mathrm{g}}$} & \multirow{2}{*}{ Lab-specific $^{e}$} & \multirow{2}{*}{ Lab-specific ${ }^{e}$} \\
\hline & Soil & & & & \\
\hline \multirow{2}{*}{$\begin{array}{c}\text { Total Petroleum } \\
\text { Hydrocarbons - } \\
\text { Diesel-Range Organics }\end{array}$} & Aqueous & \multirow{2}{*}{$\begin{array}{l}\text { 8015B } \\
\text { modified }^{c}\end{array}$} & \multirow[b]{2}{*}{$25 \mathrm{mg} / \mathrm{kg}^{\mathrm{g}}$} & \multirow[b]{2}{*}{ Lab-specific ${ }^{e}$} & \multirow[b]{2}{*}{ Lab-specific ${ }^{e}$} \\
\hline & Soil & & & & \\
\hline \multirow{2}{*}{ Pesticides } & Aqueous & \multirow{2}{*}{$8081 A^{C}$} & \multirow{2}{*}{$\begin{array}{l}\text { Parameter-Specific } \\
\text { MDCs }^{d}\end{array}$} & \multirow{2}{*}{ Lab-specific $^{e}$} & \multirow{2}{*}{ Lab-specific $^{e}$} \\
\hline & Soil & & & & \\
\hline \multicolumn{6}{|c|}{ INORGANICS } \\
\hline & To & I RCRA Meta & plus Beryllium & & \\
\hline & Aqueous & $6010 \mathrm{~B}^{\mathrm{c}}$ & $0.01 \mathrm{mg} / \mathrm{L}^{\mathrm{g}, \mathrm{h}}$ & & \\
\hline ArsenIc & Soil & $6010 \mathrm{~B}^{\mathrm{c}}$ & $1 \mathrm{mg} / \mathrm{kg}^{\mathrm{g}, \mathrm{h}}$ & & \\
\hline & Aqueous & $6010 \mathrm{~B}^{\mathrm{c}}$ & $0.20 \mathrm{mg} / \mathrm{L}^{\mathrm{g}, \mathrm{h}}$ & & \\
\hline Barium & Soil & $6010 \mathrm{~B}^{\mathrm{c}}$ & $20 \mathrm{mg} / \mathrm{kg}^{\mathrm{g}, \mathrm{h}}$ & $\begin{array}{l}\text { RPD 35\% } \\
\text { (soil) }\end{array}$ & Matrix Spike \\
\hline Domplimm & Aqueous & $6010 B^{c}$ & $0.005 \mathrm{mg} / \mathrm{L}^{\mathrm{g}, \mathrm{h}}$ & and $20 \%$ & Recovery \\
\hline Beryılium & Soil & $6010 \mathrm{~B}^{\mathrm{c}}$ & $0.5 \mathrm{mg} / \mathrm{kg}^{\mathrm{g}, \mathrm{h}}$ & & \\
\hline & Aqueous & $6010 B^{c}$ & $0.005 \mathrm{mg} / \mathrm{L}^{\mathrm{g}, \mathrm{h}}$ & Absolute & Laboratory \\
\hline Cadmium & Soil & $6010 B^{c}$ & $0.5 \mathrm{mg} / \mathrm{L}^{\mathrm{g}, \mathrm{h}}$ & $\begin{array}{l}\text { Difference } \\
<2 \times R L \text { (soil) }\end{array}$ & $\begin{array}{c}\text { Control Sample } \\
\text { Recovery }\end{array}$ \\
\hline & Aqueous & $6010 \mathrm{~B}^{\mathrm{c}}$ & $0.01 \mathrm{mg} / \mathrm{L}^{\mathrm{g}, \mathrm{h}}$ & and $<1 \times R L$ & at $80-120^{\mathrm{h}}$ \\
\hline Chromium & Soil & $6010 \mathrm{~B}^{\mathrm{c}}$ & $1 \mathrm{mg} / \mathrm{kg}^{\mathrm{g}, \mathrm{h}}$ & (aqueous) & \\
\hline & Aqueous & $6010 \mathrm{~B}^{\mathrm{c}}$ & $0.003 \mathrm{mg} / \mathrm{L}^{\mathrm{g}, \mathrm{h}}$ & & \\
\hline Lead & Soil & $6010 \mathrm{~B}^{\mathrm{c}}$ & $0.3 \mathrm{mg} / \mathrm{kg}^{\mathrm{g}, \mathrm{h}}$ & & \\
\hline
\end{tabular}


Table 3-5

Analytical Requirements for Chemical COPCs for CAU 166*

(Page 2 of 2 )

\begin{tabular}{|c|c|c|c|c|c|}
\hline Parameter/Analyte & $\begin{array}{l}\text { Medium } \\
\text { or } \\
\text { Matrix }\end{array}$ & $\begin{array}{l}\text { Analytical } \\
\text { Method }\end{array}$ & $\begin{array}{c}\text { Minimum } \\
\text { Detectable } \\
\text { Concentration } \\
\text { (MDC) }\end{array}$ & $\begin{array}{l}\text { Laboratory } \\
\text { Precision } \\
\text { (RPD) }^{\mathrm{a}}\end{array}$ & $\begin{array}{c}\text { Percent } \\
\text { Recovery } \\
(\% R)^{\mathrm{b}}\end{array}$ \\
\hline \multirow{2}{*}{ Mercury } & Aqueous & $7470 A^{c}$ & $0.0002 \mathrm{mg} / \mathrm{L}^{\mathrm{g}, \mathrm{h}}$ & \multirow{3}{*}{$\begin{array}{l}\text { RPD 35\% } \\
\text { (soil) }^{\mathrm{g}} \\
\text { and 20\% } \\
\text { (aqueous) }^{\mathrm{h}}\end{array}$} & \multirow{3}{*}{$\begin{array}{l}\text { Matrix Spike } \\
\text { Recovery } \\
\text { at } 75-125^{h}\end{array}$} \\
\hline & Soil & $7471 A^{c}$ & $0.1 \mathrm{mg} / \mathrm{kg}^{\mathrm{g}, \mathrm{h}}$ & & \\
\hline \multirow{2}{*}{ Selenium } & Aqueous & $6010 B^{c}$ & $0.005 \mathrm{mg} / \mathrm{L}^{\mathrm{g}, \mathrm{h}}$ & & \\
\hline & Soil & $6010 B^{c}$ & $0.5 \mathrm{mg} / \mathrm{kg}^{\mathrm{g}, \mathrm{h}}$ & \multirow{3}{*}{$\begin{array}{c}\text { Absolute } \\
\text { Difference } \\
<2 \times R L \text { (soil) } \\
\text { and }<1 \times R L \\
\text { (aqueous) }\end{array}$} & \multirow{3}{*}{$\begin{array}{l}\text { Laboratory } \\
\text { Control Sample } \\
\text { Recovery } \\
\text { at } 80-120^{\mathrm{h}}\end{array}$} \\
\hline \multirow[b]{2}{*}{ Silver } & Aqueous & $6010 B^{c}$ & $0.01 \mathrm{mg} / \mathrm{L}^{\mathrm{g}, \mathrm{h}}$ & & \\
\hline & Soil & $6010 B^{c}$ & $1 \mathrm{mg} / \mathrm{kg}^{\mathrm{g}, \mathrm{h}}$ & & \\
\hline
\end{tabular}

${ }^{*}$ Note: See Table 3-4 for the analytical requirements for radionuclides.

aPrecision is estimated from the RPD of the laboratory or field duplicates MSD and LCSD are spiked. It is calculated by: $\operatorname{RPD}=100 \times\left(\left|A_{1}-A_{2}\right|\right) /\left[\left(A_{1}+A_{2}\right) / 2\right]$, where $A_{1}=$ Concentration of the parameter in the initial sample aliquot, $A_{2}=$ Concentration of the parameter in the duplicate sample aliquot.

${ }^{b}$ Accuracy is assessed from the \%R of parameters spiked into a blank or sample matrix of interest, or from the recovery of surrogate compounds spiked into each sample. The recovery of each spiked parameter is calculated by: $\% R=100 \times\left(A_{s}-A_{u} / A_{n}\right)$, where $A_{s}=$ Concentration of the parameter in the spiked sample, $A_{u}=$ Concentration of the parameter in the unspiked sample, $A_{n}=$ Concentration increase that should result from spiking the sample.

'U.S. EPA Test Methods for Evaluating Solid Waste Physical/Chemical Methods, 3rd Edition, Parts 1-4, (SW-846) CD ROM, Washington, D.C. (EPA,1996).

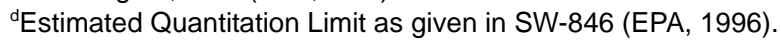

${ }^{e} \mathrm{RPD}$ and \%R Performance Criteria are developed and generated in-house by the laboratory according to approved laboratory procedures.

'EPA Contract Laboratory Program Statement of Work for Organic Analysis (EPA, 1988b, 1991, 1994c).

IIndustrial Sites Quality Assurance Project Plan (NNSA/NV, 2002a).

hEPA Contract Laboratory Program Statement of Work for Inorganic Analysis (EPA, 1994a, b).

LCSD = Laboratory control sample duplicate

$\mathrm{mg} / \mathrm{kg}=$ Milligrams per kilogram

$\mathrm{mg} / \mathrm{L}=$ Milligrams per liter

MSD = Matrix spike duplicate

RCRA = Resource Conservation and Recovery Act

$\mathrm{RPD}=$ Relative percent difference 


\subsection{Field Investigation}

This section contains a description of the activities to be conducted to gather and document information from the CAU 166 field investigation.

\subsection{Technical Approach}

The information necessary to satisfy the DQO data needs will be generated for each CAU 166 CAS by collecting and evaluating samples generated during a field investigation. The presence and nature of contamination at CASs 18-01-01 and 18-99-03 as well as portions of CASs 03-42-01 and 05-19-02 will be evaluated using a judgmental approach by collecting samples at biased locations that are determined to be most probable to contain COCs if they are present anywhere within the CAS. These locations will be determined based on their identification using the biasing factors listed in Section A.5.2.1.

A probabilistic approach will be used to collect and evaluate samples at CASs 02-42-01, 02-42-02, 02-99-10 as well as portions of CASs 03-42-01 and 05-19-02 because biasing factors are not present to adequately select sample locations.

If there is a waste present that, if released, has the potential to release significant contamination into site environmental media, that waste will be sampled. If it is determined that a COC is present at any CAS, that CAS will be further addressed by determining the extent of contamination before evaluating corrective action alternatives.

Because this CAIP only addresses contamination originating from the CAU, it may be necessary to distinguish overlapping contamination originating from other sources. For example, widespread surface radiological contamination originating from atmospheric tests will not be addressed in the CAU 166 investigation. To determine whether contamination is from releases associated with the CAU or from other sources, soil samples may be collected from background locations at selected CASs. For example, a portion of CASs 18-01-01 and 18-99-03 is located in a contamination area. The soil in the contamination area is covered by the Soils Project (CAU 107, CAS 18-45-03). Samples may be collected from outside of the posted contamination area to differentiate the potential 
radiological contamination from CASs 18-01-01 and 18-99-03 and the outfall from the Little Feller II testing.

Modifications to the investigative strategy may be required if unexpected field conditions are encountered at any CAS. Significant modifications shall be justified and documented on a Record of Technical Change before implementation. If an unexpected condition indicates that conditions are significantly different than the corresponding CSM, the activity will be rescoped and the identified decision makers will be notified.

\subsection{Field Activities}

Field activities at CAU 166 include site preparation, sample location selection, and sample collection activities.

\subsubsection{Site Preparation Activities}

Site preparation will be conducted by the NTS Management and Operating Contractor prior to the investigation. Site preparation may include, but is not limited to:

- Relocation or removal of surface debris, equipment, structures, and brush.

- Construction of hazardous waste accumulation areas (HWAAs) and site exclusion zones.

- Providing sanitary facilities.

- Constructing decontamination facilities.

- Temporarily moving staged equipment.

Before mobilization for collecting investigation samples, the following preparatory activities will also be conducted:

- Perform visual surveys at all CASs to identify any staining, discoloration, disturbance of native soils, or any other indication of potential contamination.

\subsubsection{Sample Location Selection}

At CASs 18-01-01, 18-99-03, and portions of CASs 03-42-01 and 05-19-02, biasing factors (including field-screening results) will be used to select the most appropriate samples from a particular location for submittal to the analytical laboratory. Biasing factors to be used for selection 
of sampling locations are listed in Section A.5.2.1. As biasing factors are identified and used for selection of sampling locations, they will be documented in the appropriate field documents.

At CASs 02-42-01, 02-42-02, 02-99-10, and a portion of CASs 03-42-01 and 05-19-02, a probabilistic sampling approach will be implemented. Sample locations at these CASs are specified in Appendix C. Appendix C briefly reviews the methodology and computational approach for probabilistic sampling, and lists the sample size and locations as calculated by the Visual Sample Plan (VSP) software program.

The CAS-specific sampling strategy and the estimated locations of biased samples for each CAS are presented in Appendix A. The number, location, and spacing of step-outs may be modified by the Task Manager or Site Supervisor, as warranted by site conditions, to achieve DQO criteria stipulated in Appendix A. Where sampling locations are modified by the Task Manager or Site Supervisor, the justification for these modifications will be documented in the field logbook.

\subsubsection{Sample Collection}

The CAU 166 sampling program will consist of the following activities:

- Collect and analyze samples from locations as described in this section.

- $\quad$ Collect required QC samples.

- Collect waste management samples.

- Collect soil samples from background locations, if necessary.

- Perform radiological characterization surveys of construction materials and debris as necessary for disposal purposes.

- Record global positioning system coordinates for each environmental sample location.

Decision I surface soil samples (0 to $0.5 \mathrm{ft}$ bgs) will be collected at all CASs except CASs 18-01-01 and 18-99-03. Samples at CASs 18-01-01 and 18-99-03 (i.e., wax piles/hardened residue) will be collected below the area of the source. If biasing factors are present in soils below locations where Decision I samples were collected, subsurface Decision I soil samples will also be collected by scoop, hand augering, and backhoe excavation, as appropriate. Decision I subsurface soil samples will 
collected at depth intervals selected by the Task Manager or Site Supervisor based on biasing factors to a depth where the biasing factors are no longer present.

The contents of the metal containers in CASs 18-01-01 and 18-99-03, and the drum at CAS 05-19-02, will be sampled to characterize the waste for disposal.

Decision II sampling will consist of further defining the extent of contamination where COCs have been confirmed. Step-out (Decision II) sampling locations at each CAS will be selected based on the CSM, biasing factors, field-screening results, existing data, and the outer boundary sample locations where COCs were detected. In general, step-out sample locations will be arranged in a triangular pattern around areas containing a COC at distances based on site conditions, COC concentrations, process knowledge, and biasing factors. If COCs extend beyond step-out locations, additional Decision II samples will be collected from locations further from the source. If a spatial boundary is reached, the CSM is shown to be inadequate, or the Site Supervisor determines that extent sampling needs to be re-evaluated, work will be temporarily suspended, NDEP notified, and the investigation strategy re-evaluated. A minimum of one analytical result less than the action level from each lateral and vertical direction will be required to define the extent of COC contamination. The lateral and vertical extent of COCs will only be established based on validated laboratory analytical results (i.e., not field screening).

\subsubsection{Sample Management}

Section 3.4 provides the analytical methods and laboratory requirements (i.e., detection limits, precision, and accuracy requirements) to be used when analyzing the COPCs. The analytical program for each CAS is presented in Table 3-1. All sampling activities and QC requirements for field and laboratory environmental sampling will be conducted in compliance with the Industrial Sites QAPP (NNSA/NV, 2002a) and other applicable, approved procedures.

\subsection{Safety}

A current version of the Environmental Services Architect-Engineer Contractor's programmatic HASP and IS HASP will accompany the field documents. An FWP, or equivalent, will be prepared and approved before the field effort. As required by the DOE Integrated Safety Management System 
(ISMS) (DOE/NV, 1997b), these documents outline the requirements for protecting the health and safety of the workers and the public, and the procedures for protecting the environment. The ISMS program requires that site personnel will reduce or eliminate the possibility of injury, illness, or accidents, and protect the environment during all project activities. The following safety issues will be taken into consideration when evaluating the hazards and associated control procedures for field activities discussed in the IS HASP and FWP:

- Potential hazards to site personnel and the public include, but are not limited to: radionuclides, chemicals (e.g., heavy metals, VOCs, SVOCs, and petroleum hydrocarbons), adverse and rapidly changing weather, remote location, and motor vehicle and heavy equipment operations.

- Proper training of all site personnel to recognize and mitigate the anticipated hazards.

- Work controls to reduce or eliminate the hazards including engineering controls, substitution of less hazardous materials, and use of appropriate personal protective equipment (PPE).

- Occupational exposure monitoring to prevent overexposures to hazards such as radionuclides, chemicals, and physical agents (e.g., heat, cold, and high wind).

- Radiological surveying for alpha/beta and gamma emitters to minimize and/or control personnel exposures; use of the as-low-as-reasonably-achievable principle when addressing radiological hazards.

- Emergency and contingency planning to include medical care and evacuation, decontamination, spill control measures, and appropriate notification of project management. The same principles apply to emergency communications.

- If presumed asbestos-containing material is identified (CFR, 2003c; NAC, 2004), it will be inspected and/or samples collected by trained personnel.

\subsection{Site Restoration}

Following completion of CAI and waste management activities, the following actions will be implemented before closure of the site Real Estate/Operating Permit:

- Removal of equipment, wastes, debris, and materials associated with the CAI; and signage and fencing (unless part of a corrective action). 
- Grading to pre-investigation condition (unless changed condition is necessary under a corrective action).

- Inspection and certification that restoration activities are complete. 


\subsection{Waste Management}

Management of waste will be based on regulatory requirements, field observations, process knowledge, and laboratory results from CAU 166 investigation samples.

Disposable sampling equipment, PPE, and rinsate are considered potentially contaminated waste only by virtue of contact with potentially contaminated media (e.g., soil) or potentially contaminated debris (e.g., construction materials). Therefore, sampling and analysis of IDW, separate from analyses of site investigation samples, may not be necessary for all IDW. However, if associated investigation samples are found to contain contaminants above regulatory levels, conservative estimates of total waste contaminant concentrations may be made based on the mass of the waste, the amount of contaminated media contained in the waste, and the maximum concentration of contamination found in the media. Direct samples of IDW may also be taken to support waste characterization.

Sanitary, hazardous, radioactive, and/or mixed waste, if generated, will be managed and disposed of in accordance with applicable DOE orders, U.S. Department of Transportation (DOT) regulations, state and federal waste regulations, and agreements and permits between DOE and NDEP.

\subsection{Waste Minimization}

Investigation activities are planned to minimize IDW generation. This will be accomplished by incorporating the use of process knowledge, visual examination, and/or radiological survey and swipe results. When possible, disturbed media (such as soil removed during trenching) or debris will be returned to its original location. Contained media (e.g., soil managed as waste) as well as other IDW will be segregated to the greatest extent possible to minimize generation of hazardous, radioactive, or mixed waste. Hazardous material used at the sites will be controlled in order to limit unnecessary generation of hazardous or mixed waste. Administrative controls, including decontamination procedures and waste characterization strategies, will minimize waste generated during investigations. 


\subsection{Potential Waste Streams}

Waste generated during the investigation activities will include the potential waste streams as follows:

- Personal protective equipment and disposable sampling equipment (e.g., plastic, paper, sample containers, aluminum foil, spoons, bowls).

- Decontamination rinsate.

- Environmental media (e.g., soil).

- Surface debris in investigation area (e.g., equipment and miscellaneous items).

- Field-screening waste (e.g., spent solvent, disposable sampling equipment, and/or PPE contaminated by field-screening activities).

- Office/lunch waste.

\subsection{Investigation-Derived Waste Management}

The on-site management and ultimate disposition of IDW will be determined based on the waste type (e.g., sanitary, low-level, hazardous, hydrocarbon, mixed) or the combination of waste types.

A determination of the waste type will be guided by several factors, including, but not limited to: the analytical results of samples either directly or indirectly associated with the waste, historical site knowledge, knowledge of the waste generation process, field observations, field-monitoring/ screening results, and/or radiological survey/swipe results.

Table 4-2 of the NV/YMP RadCon Manual (NNSA/NSO, 2004) shall be used to determine if such materials are radioactive-contaminated. On-site IDW management requirements by waste type are detailed in the following sections. Applicable waste management regulations and requirements are listed in Table 5-1.

\subsubsection{Sanitary Waste}

Sanitary IDW generated at each CAS will be collected, managed, and disposed of in accordance with the sanitary waste management regulations and the permits for operation of the NTS 10c Industrial Waste Landfill. 
Table 5-1

Waste Management Regulations and Requirements

\begin{tabular}{|c|c|c|}
\hline Waste Type & Federal Regulation & Additional Requirements \\
\hline Solid (nonhazardous) & $\mathrm{N} / \mathrm{A}$ & $\begin{array}{c}\text { NRS }^{\mathrm{a}} 444.440-444.620 \\
\text { NAC }^{\mathrm{b}} 444.570-444.7499 \\
\text { NTS Landfill Permit SW13.097.04 } \\
\text { NTS Landfill Permit SW13.097.03 }\end{array}$ \\
\hline Liquid/Rinsate (nonhazardous) & $\mathrm{N} / \mathrm{A}$ & $\begin{array}{l}\text { Water Pollution Control General Permit } \\
\text { GNEV93001, Rev. 3iii }\end{array}$ \\
\hline Hazardous & $\begin{array}{c}\text { RCRA }^{\dagger}, \\
40 \text { CFR 260-282 }\end{array}$ & $\begin{array}{c}\mathrm{NRS}^{\mathrm{a}} 459.400-459.600 \\
\mathrm{NAC}^{\mathrm{b}} 444.850-444.8746 \\
\mathrm{POC}^{\mathrm{g}}\end{array}$ \\
\hline Low-Level Radioactive & $\mathrm{N} / \mathrm{A}$ & DOE Orders and NTSWAC ${ }^{\text {h }}$ \\
\hline Mixed & $\begin{array}{c}\text { RCRA }^{\mathrm{f}}, \\
40 \mathrm{CFR}^{260-282}\end{array}$ & $\begin{array}{l}\text { NTSWAC } \\
\text { POC }^{\mathrm{h}}\end{array}$ \\
\hline Hydrocarbon & $\mathrm{N} / \mathrm{A}$ & $\begin{array}{c}\text { NTS Landfill Permit SW13.097.02 } \\
\text { NAC 445A.2272 }\end{array}$ \\
\hline Polychlorinated Biphenyls & $\begin{array}{l}\text { TSCA }^{\mathrm{j}} \\
40 \text { CFR } 761\end{array}$ & $\begin{array}{l}\text { NRS }^{a} 459.400-459.600 \\
\text { NAC }^{b} 444.940-444.9555\end{array}$ \\
\hline Asbestos & $\begin{array}{c}\text { TSCA } \\
40 \text { CFR } 763\end{array}$ & $\begin{array}{l}N^{N} S^{a} \text { 618.750-618.840 } \\
\text { NAC }^{b} 444.965-444.976\end{array}$ \\
\hline
\end{tabular}

${ }^{a}$ Nevada Revised Statutes (NRS, 2005a, b, c)

${ }^{\mathrm{b}}$ Nevada Administrative Code (NAC, 2005)

${ }^{\mathrm{C}}$ Area 23 Class II Solid Waste Disposal Site (NDEP, 1997a)

dArea 9 Class III Solid Waste Disposal Site (NDEP, 1997c)

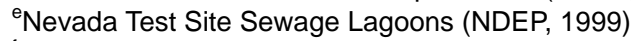

${ }^{\mathrm{f}}$ Resource Conservation and Recovery Act (CFR, 2003a)

${ }^{9}$ Nevada Test Site Performance Objective for the Certification of Nonradioactive Hazardous Waste (BN, 1995)

${ }^{\mathrm{h}}$ Nevada Test Site Waste Acceptance Criteria, Revision 6 (NNSA/NSO, 2005)

'Area 6 Class III Solid Waste Disposal Site for hydrocarbon waste (NDEP, 1997b)

${ }^{\mathrm{j}}$ Toxic Substance Control Act (CFR, 2003b, c)

${ }^{k}$ NAC 445A.2272 (NAC, 2005)

$\mathrm{CFR}=$ Code of Federal Regulations

$\mathrm{DOE}=$ U.S. Department of Energy

$\mathrm{N} / \mathrm{A}=$ Not applicable

NAC $=$ Nevada Administrative Code

NDEP $=$ Nevada Division of Environmental Protection

NRS $=$ Nevada Revised Statutes

NTS $=$ Nevada Test Site

NTSWAC $=$ Nevada Test Site Waste Acceptance Criteria

$P O C=$ Nevada Test Site Performance Objective for the Certification of Nonradioactive Hazardous Waste

RCRA $=$ Resource Conservation and Recovery Act

TSCA = Toxic Substance Control Act

Sanitary IDW generated at each CAS will be collected in plastic bags, sealed, labeled with the CAS number from the site where it was generated, and dated. The waste will then be placed in a roll-off 
box located in Mercury, or other approved roll-off box location. The number of bags of sanitary IDW placed in the roll-off box will be counted as they are placed in the roll-off box, logged, and documented in the Field Activity Daily Log. These logs will provide necessary tracking information for ultimate disposal in the 10c Industrial Waste Landfill. Office trash and lunch waste will be placed in the dumpster to be transported to the sanitary landfill for disposal.

\subsubsection{Low-Level Radioactive Waste}

Radiological swipe surveys and/or direct-scan surveys may be conducted on reusable sampling equipment and the PPE and disposable sampling equipment waste streams exiting a radiologically controlled area (RCA). This allows for the immediate segregation of radioactive waste from waste that may be unrestricted regarding radiological release. Removable contamination limits, as defined in Table 4-2 of the current version of the NV/YMP RadCon Manual (NNSA/NSO, 2004), will be used to determine whether such waste may be declared unrestricted regarding radiological release versus being declared radioactive waste. Direct sampling of the waste may be conducted to aid in determining whether a particular waste unit (e.g., drum of soil) contains low-level radioactive waste, as necessary. Waste that is determined to be below the values of Table 4-2, by either direct radiological survey/swipe results or through process knowledge, will not be managed as potential radioactive waste but will be managed in accordance with the appropriate section of this document. Wastes in excess of Table 4-2 values will be managed as potential radioactive waste and be managed in accordance with this section and any other applicable sections of this document.

Low-level radioactive waste, if generated, will be managed in accordance with the contractor-specific waste certification program plan, DOE orders, and the requirements of the current version of the Nevada Test Site Waste Acceptance Criteria (NTSWAC) (NNSA/NSO, 2005). Potential radioactive waste drums containing soil, PPE, disposable sampling equipment, and/or rinsate may be staged at a designated RMA or RCA when full or at the end of an investigation phase. The waste drums will remain at the RMA pending certification and disposal under NTSWAC requirements (NNSA/NSO, 2005). 


\subsubsection{Hazardous Waste}

Suspected hazardous wastes will be placed in DOT-compliant containers. All containerized hazardous waste will be handled, inspected, and managed in accordance with Title 40 CFR 265 Subpart I (CFR, 2003a). These provisions include managing the waste in containers compatible with the waste type, and segregating incompatible waste types so that in the event of a spill, leak, or release, incompatible wastes shall not contact one another.

The CAU will have waste accumulation areas established according to the needs of the project. Satellite accumulation areas and HWAAs will be managed consistent to the requirements of federal and state regulations (CFR, 2003a; NAC, 2005). The HWAAs will be properly controlled for access, and will be equipped with spill kits and appropriate spill containment. The HWAAs will be covered under a site-specific emergency response and contingency action plan until such time that the waste is determined to be nonhazardous or all containers of hazardous waste have been removed from the storage area. Hazardous waste will be characterized in accordance with the requirement of Title 40 Code of Federal Regulations (CFR) 261. The RCRA-listed waste has not been identified at CAU 166. Any waste determined to be hazardous will be managed and transported in accordance with RCRA and DOT requirements to a permitted treatment, storage, and disposal facility (CFR, 2003a).

\subsubsection{Hydrocarbon Waste}

Hydrocarbon soil waste containing more than $100 \mathrm{mg} / \mathrm{kg}$ of TPH will be managed on site in a drum or other appropriate container until fully characterized. Hydrocarbon waste may be disposed of at a designated hydrocarbon landfill (NDEP, 1997b), an appropriate hydrocarbon waste management facility (e.g., recycling facility), or other method in accordance with Nevada regulations.

\subsubsection{Mixed Low-Level Waste}

Mixed waste, if generated, shall be managed and dispositioned according to the requirements of RCRA (CFR, 2003a) or subject to agreements between NNSA/NSO and the State of Nevada, as well as DOE requirements for radioactive waste. The waste will be marked with the words "Hazardous Waste Pending Analysis and Radioactive Waste Pending Analysis.” Waste characterized as mixed will not be stored for a period of time that exceeds the requirements of RCRA unless subject to 
agreements between NNSA/NSO and the State of Nevada. The mixed waste shall be transported via an approved hazardous waste/radioactive waste transporter to the NTS transuranic waste storage pad for storage pending treatment or disposal. Mixed waste with hazardous waste constituent concentrations below Land Disposal Restrictions may be disposed of at the NTS Area 5 Radioactive Waste Management Site if the waste meets the requirements of the NTSWAC (NNSA/NSO, 2005), the NTS NDEP permit for Hazardous Waste Management Facility (NEV HW0021 [NDEP, 2005]), and the RCRA Part B Permit Application for Waste Management Activities at the Nevada Test Site (DOE/NV, 1999). Mixed waste constituent concentrations exceeding Land Disposal Restrictions will require development of a treatment and disposal plan under the requirements of the Mutual Consent Agreement between DOE and the State of Nevada (NDEP, 1995).

\subsubsection{Polychlorinated Biphenyls}

The management of polychlorinated biphenyls (PCBs) is governed by the Toxic Substances Control Act (TSCA) (USC, 1976) and its implementing regulations at 40 CFR 761 (CFR, 2003b).

Polychlorinated biphenyl contamination may be found as a sole contaminant or in combination with any of the types of waste discussed in this document. For example, PCBs may be a co-contaminant in soil that contains a RCRA “characteristic” waste (PCB/hazardous waste), or in soil that contains radioactive wastes (PCB/radioactive waste), or even in mixed waste (PCB/radioactive/hazardous waste). The IDW will initially be evaluated using analytical results for media samples from the investigation. If any type of PCB waste is generated, it will be managed according to 40 CFR 761 (CFR, 2003b) as well as State of Nevada requirements, (NAC, 2004) guidance, and agreements with NNSA/NSO.

\subsection{Management of Specific Waste Streams}

\subsubsection{Personal Protective Equipment}

Personal protective equipment and disposable sampling equipment will be inspected visually for stains, discoloration, and gross contamination as the waste is generated, and evaluated for radiological contamination. Staining and/discoloration will be assumed to be the result of contact with potentially contaminated media such as soil, sludge, or liquid. Gross contamination is the visible contamination of an item (e.g., clumps of soil/sludge on a sampling spoon or free liquid smeared on a 
glove). While gross contamination can often be removed through decontamination methods, removal of gross contamination from small items, such as gloves or booties is not typically conducted. Any IDW that meets this description will be segregated and managed as potentially "characteristic" hazardous waste. This segregated population of waste will be (1) assigned the characterization of the soil/sludge that was sampled, (2) sampled directly, or (3) undergo further evaluation using the soil/sludge sample results to determine how much soil/sludge would need to be present in the waste to exceed regulatory levels. Waste that is determined to be hazardous will be entered into an approved waste management system, where it will be managed and dispositioned according to RCRA requirements or subject to agreements between NNSA/NSO and the State of Nevada. The PPE and equipment that is not visibly stained, discolored, or grossly contaminated and within radiological free-release criteria, will be managed as nonhazardous sanitary waste.

\subsubsection{Management of Decontamination Rinsate}

Rinsate at CAU 166 will not be considered hazardous waste unless there is evidence that the rinsate may display a RCRA characteristic. Evidence may include such things as the presence of a visible sheen, high or low $\mathrm{pH}$ (e.g., $\leq 2, \geq 12$ ), or association with equipment/materials used to respond to a release/spill of a hazardous waste/substance. Decontamination rinsate that is potentially hazardous (using associated sample results and/or process knowledge) will be managed as characteristic hazardous waste (CFR, 2003a). The regulatory status of the potentially hazardous rinsate will be determined through the application of associated sample results or through direct sampling. If the associated samples do not indicate the presence of hazardous constituents, then the rinsate will be considered nonhazardous.

The disposal of nonhazardous rinsate will be consistent with guidance established in current NNSA/NSO Fluid Management Plans for the NTS as follows:

- Rinsate that is determined to be nonhazardous and contaminated to less than 5 times Safe Drinking Water Standards (SDWS) is not restricted as to disposal. Nonhazardous rinsate contaminated at 5 to 10 times the SDWS will be disposed of in an established infiltration basin, or solidified and disposed of as sanitary waste or low-level waste, in accordance with the respective sections of this document. 
- Nonhazardous rinsate contaminated at greater than 10 times SDWS will be disposed of in a lined basin, or solidified and disposed of as sanitary waste, or low-level waste, according to the respective sections of this document.

\subsubsection{Management of Soil}

This waste stream consists of soil removed for disposal during soil sampling, excavation, and/or drilling. This waste stream will be characterized based on laboratory analytical results from representative locations. If the soil is determined to potentially contain COCs, the material will be managed on site or containerized for transportation to an appropriate disposal site.

On-site management of the waste soil will be allowed only if it is managed within an area of concern and it is appropriate to defer the management of the waste until the final remediation of the site. If this option is chosen, the waste soil shall be protected from run-on and run-off using appropriate protective measures based on the type of contaminant(s) (e.g., covered with plastic and bermed).

Management of soil waste for disposal consists of placing the waste in containers, labeling the containers, temporarily storing the containers until shipped, and shipping the waste to a disposal site. The containers, labels, management of stored waste, transport to the disposal site, and disposal shall be appropriate for the type of waste (e.g., hazardous, hydrocarbon, mixed).

Note that soils placed back into a borehole or excavation in the same approximate location of origination is not considered to be a waste.

\subsubsection{Management of Debris}

This waste stream can vary depending on site conditions. Debris that requires removal for the investigation activities (soil sampling or excavation) must be characterized for proper management and disposition. Historical site knowledge, knowledge of the waste generation process, field observations, field-monitoring/screening results, radiological survey/swipe results and/or the analytical results of samples either directly or indirectly associated with the waste may be used to characterize the debris. Debris will be visually inspected for stains, discoloration, and gross contamination. Debris may be deemed reusable, recyclable, sanitary waste, hazardous waste, PCB waste, or low-level waste. Waste that is not sanitary will be entered into an approved waste management system, where it will be managed and dispositioned according to federal, state 
requirements, and agreements between NNSA/NSO and the State of Nevada. The debris will be managed on site by berming and covering next to the excavation, by placement in a container(s), or left in the footprint of the CAS and its disposition deferred until implementation of corrective action at the site.

\subsubsection{Field-Screening Waste}

The use of field test kits and/or instruments may result in the generation of small quantities of hazardous wastes. If hazardous waste is produced by field screening, it will be segregated from other IDW and managed in accordance with the hazardous waste regulations (CFR, 2003a). For sites where field-screening samples contain radioactivity above background levels, field-screening methods that have the potential to generate hazardous waste will not be used, thus avoiding the potential to generate mixed waste. In the event a mixed waste is generated, the waste will be managed according to Section 5.3.5. 


\subsection{Quality Assurance/Quality Control}

The overall objective of the characterization activities described in this CAIP is to collect accurate and defensible data to support the selection and implementation of a closure alternative for each CAS in CAU 166. Sections 6.1 and 6.2 discuss the collection of required QC samples in the field and QA requirements for laboratory/analytical data to achieve closure. Unless otherwise stated in this CAIP or required by the results of the DQO process (see Appendix A), this investigation will adhere to the Industrial Sites QAPP (NNSA/NV, 2002a).

\subsection{Quality Control Sampling Activities}

Field QC samples will be collected in accordance with established procedures. Field QC samples are collected and analyzed to aid in determining the validity of environmental sample results. The number of required QC samples depends on the types and number of environmental samples collected. The minimum frequency of collecting and analyzing QC samples for this investigation, as determined in the DQO process, include:

- $\quad$ Trip blanks (1 per sample cooler containing VOC environmental samples)

- Equipment rinsate blanks (1 per sampling event for each type of decontamination procedure)

- $\quad$ Source blanks (1 per lot of source material that contacts sampled media)

- Field duplicates (1 per 20 environmental samples or 1 per CAS per matrix, if less than 20 collected)

- Field blanks (may be 1 per 20 environmental samples, 1 per day, or 1 per CAS depending on site conditions and agreement of DQO participants)

- Laboratory QC samples (1 per 20 environmental samples or 1 per CAS per matrix, if less than 20 collected)

Additional QC samples may be submitted based on site conditions at the discretion of the Task Manager or Site Supervisor. Field QC samples shall be analyzed using the same analytical procedures implemented for associated environmental samples. Additional details regarding field QC samples are available in the Industrial Sites QAPP (NNSA/NV, 2002a). 


\subsection{Laboratory/Analytical Quality Assurance}

Criteria for the investigation, as stated in the DQOs (see Appendix A) and except where noted, require laboratory analytical quality data be used for making critical decisions. Rigorous QA/QC will be implemented for all laboratory samples including documentation, data verification and validation of analytical results, and an assessment of DQIs as they relate to laboratory analysis.

\subsubsection{Data Validation}

Data verification and validation will be performed in accordance with the Industrial Sites QAPP (NNSA/NV, 2002a), except where otherwise stipulated in this CAIP. All chemical and radiological laboratory data from samples that are collected and analyzed will be evaluated for data quality according to company-specific procedures. The data will be reviewed to ensure that all suspected samples were appropriately collected, analyzed, and the results passed data validation criteria. Validated data, including estimated data (i.e., J-qualified), will be assessed to determine whether they meet the DQO requirements of the investigation and the performance criteria for the DQIs. The results of this assessment will be documented in the Corrective Action Decision Document (CADD). If the DQOs were not met, corrective actions will be evaluated, selected, and implemented (e.g., refine CSM or resample to fill data gaps).

\subsubsection{Data Quality Indicators}

The DQIs are qualitative and quantitative descriptors used in interpreting the degree of acceptability or utility of data. Data quality indicators are used to evaluate the entire measurement system and laboratory measurement processes (i.e., analytical method performance) as well as to evaluate individual analytical results (i.e., parameter performance). The quality and usability of data used to make DQO decisions will be assessed based on the following DQIs:

- Precision

- Accuracy/bias

- Representativeness

- Comparability

- Completeness

- Sensitivity 
Table 6-1 provides the established analytical method/measurement system performance criteria for each of the DQIs and the potential impacts to the decision if the criteria are not met. The following subsections discuss the DQIs that will be used to assess the quality of laboratory data. Due to changes in analytical methodology and changes in analytical laboratory contracts, criteria for precision and accuracy in Tables 3-4 and 3-5 that vary from corresponding information in the QAPP will supersede that information in the QAPP (NNSA/NV, 2002a).

Table 6-1

Laboratory and Analytical Performance Criteria for CAU 166 Data Quality Indicators

\begin{tabular}{|c|c|c|}
\hline $\begin{array}{l}\text { Data Quality } \\
\text { Indicator }\end{array}$ & Performance Metric & $\begin{array}{l}\text { Potential Impact on Decision } \\
\text { If Performance Metric Not Met }\end{array}$ \\
\hline Precision & $\begin{array}{l}\text { At least } 80 \% \text { of the sample results for each } \\
\text { measured analyte are not qualified for precision } \\
\text { based on the RPD criteria for each analytical } \\
\text { method-specific and laboratory-specific criteria } \\
\text { presented in Section 6.2.3. }\end{array}$ & $\begin{array}{l}\text { Affected analytical results from each } \\
\text { affected CAS will be assessed to determine } \\
\text { whether there is sufficient confidence in } \\
\text { analytical results to use the data in making } \\
\text { DQO decisions. }\end{array}$ \\
\hline Accuracy & $\begin{array}{l}\text { At least } 80 \% \text { of the sample results for each } \\
\text { measured analyte are not qualified for accuracy } \\
\text { based on the method-specific and } \\
\text { laboratory-specific criteria presented in } \\
\text { Section } 6.2 .4 \text {. }\end{array}$ & $\begin{array}{l}\text { Affected analytical results from each } \\
\text { affected CAS will be assessed to determine } \\
\text { whether there is sufficient confidence in } \\
\text { analytical results to use the data in making } \\
\text { DQO decisions. }\end{array}$ \\
\hline Sensitivity & $\begin{array}{l}\text { Minimum detectable concentrations are less } \\
\text { than or equal to respective FALs. }\end{array}$ & $\begin{array}{l}\text { Cannot determine whether COCs are } \\
\text { present or migrating at levels of concern. }\end{array}$ \\
\hline Comparability & $\begin{array}{l}\text { Sampling, handling, preparation, analysis, } \\
\text { reporting, and data validation are performed } \\
\text { using standard methods and procedures. }\end{array}$ & $\begin{array}{l}\text { Inability to combine data with data obtained } \\
\text { from other sources and/or inability to } \\
\text { compare data to regulatory action levels. }\end{array}$ \\
\hline Representativeness & $\begin{array}{l}\text { Samples contain contaminants at concentrations } \\
\text { present in the environmental media from which } \\
\text { they were collected. }\end{array}$ & $\begin{array}{l}\text { Analytical results will not represent true site } \\
\text { conditions. Inability to make appropriate } \\
\text { DQO decisions. }\end{array}$ \\
\hline Completeness & $\begin{array}{l}80 \% \text { of the CAS-specific COPC analytes have } \\
\text { valid results. } \\
100 \% \text { of CAS-specific targeted analytes have } \\
\text { valid results. }\end{array}$ & $\begin{array}{l}\text { Cannot support/defend decision on } \\
\text { whether COCs are present. }\end{array}$ \\
\hline Extent Completeness & $\begin{array}{l}100 \% \text { of COC analytes used to define extent } \\
\text { have valid results. }\end{array}$ & $\begin{array}{l}\text { Extent of contamination cannot be } \\
\text { accurately determined. }\end{array}$ \\
\hline $\begin{array}{l}\text { Clean Closure } \\
\text { Completeness }\end{array}$ & $100 \%$ of targeted analytes have valid results. & $\begin{array}{l}\text { Cannot determine whether COCs remain in } \\
\text { soil. }\end{array}$ \\
\hline
\end{tabular}

CAS $=$ Corrective action site

$\mathrm{COC}=$ Contaminant of concern

$\mathrm{COPC}=$ Contaminant of potential concern

$\mathrm{DQO}=$ Data quality objective

$\mathrm{FAL}=$ Final action level

ND = Normalized difference

$\mathrm{RPD}=$ Relative percent difference 


\subsubsection{Precision}

Precision is a measure of the repeatability of the analysis process from sample collection through analysis results. It is used to assess the variability between two equal samples.

Determinations of precision will be made for field duplicate samples and laboratory duplicate samples. Field duplicate samples will be collected simultaneously with samples from the same source under similar conditions in separate containers. The duplicate sample will be treated independently of the original sample in order to assess field impacts and laboratory performance on precision through a comparison of results. Laboratory precision is evaluated as part of the required laboratory internal QC program to assess performance of analytical procedures. The laboratory sample duplicates are an aliquot, or subset, of a field sample generated in the laboratory. They are not a separate sample but a split, or portion, of an existing sample. Typically, laboratory duplicate QC samples may include matrix spike duplicate (MSD) and laboratory control sample (LCS) duplicate samples for organic, inorganic, and radiological analyses.

Precision is a quantitative measure used to assess overall analytical method and field-sampling performance as well as to assess the need to "flag" (qualify) individual parameter results when corresponding QC sample results are not within established control limits.

The criteria used for the assessment of chemical precision when both results are greater than or equal to 5 times the reporting limit (RL) is 20 percent and 35 percent for aqueous and soil samples, respectively. When either result is less than 5 times RL, a control limit of \pm 1 times RL and \pm 2 times $\mathrm{RL}$ for aqueous and soil samples, respectively, is applied to the absolute difference.

The criteria used for the assessment of radiological precision when both results are greater than or equal to 5 times MDC is 20 percent for aqueous samples and 35 percent for soil samples. When either result is less than 5 times MDC, the normalized difference (ND) should be between -2 and +2 for aqueous and soil samples. The parameters to be used for assessment of precision for duplicates are listed in Table 3-5.

Any values outside the specified criteria do not necessarily result in the qualification of analytical data. It is only one factor in making an overall judgment about the quality of the reported analytical results. The performance metric for assessing the DQI of precision on DQO decisions (Table 6-1) is 
that at least 80 percent of sample results for each measured contaminant are not qualified due to duplicates exceeding the criteria. If this performance is not met, an assessment will be conducted in the investigation report on the impacts to DQO decisions specific to affected contaminants and CASs.

\subsubsection{Accuracy}

Accuracy is a measure of the closeness of an individual measurement to the true value. It is used to assess the performance of laboratory measurement processes.

Accuracy is determined by analyzing a reference material of known parameter concentration or by reanalyzing a sample to which a material of known concentration or amount of parameter has been added (spiked). Accuracy will be evaluated based on results from three types of spiked samples: matrix spike (MS), LCS, and surrogates (organics). The LCS sample is analyzed with the field samples using the same sample preparation, reagents, and analytical methods employed for the samples. One LCS will be prepared with each batch of samples for analysis by a specific measurement.

The criteria used for the assessment of inorganic chemical accuracy are 75 to 125 percent for MS recoveries and 80 to 120 percent for LCS recoveries. For organic chemical accuracy, MS and LCS laboratory-specific percent recovery criteria developed and generated in-house by the laboratory according to approved laboratory procedures are applied. The criteria used for the assessment of radiochemical accuracy are 80 to120 percent for LCS and MS recoveries.

Any values outside the specified criteria do not necessarily result in the qualification of analytical data. It is only one factor in making an overall judgment about the quality of the reported analytical results. Factors beyond laboratory control, such as sample matrix effects, can cause the measured values to be outside of the established criteria. Therefore, the entire sampling and analytical process may be evaluated when determining the usability of the affected data.

The performance metric for assessing the DQI of accuracy on DQO decisions (Table 6-1) is that at least 80 percent of the sample results for each measured contaminant are not qualified for accuracy. If this performance is not met, an assessment will be conducted in the investigation report on the impacts to DQO decisions specific to affected contaminants and CASs. 


\subsubsection{Representativeness}

Representativeness is the degree to which sample characteristics accurately and precisely represent characteristics of a population or an environmental condition (EPA, 1987). Representativeness is assured by carefully developing the sampling strategy during the DQO process such that false negative and false positive decision errors are minimized. The criteria listed in DQO Step 6 - Specify the Tolerable Limits on Decision Errors are:

- For Decision I judgmental sampling, a high degree of confidence that the sample locations selected will identify COCs if present anywhere within the CAS.

- For Decision I probabilistic sampling, a high degree of confidence that the sample locations selected will represent contamination of the CAS.

- A high degree of confidence that analyses conducted will be sufficient to detect any COCs present in the samples.

- For Decision II, a high degree of confidence that the sample locations selected will identify the extent of COCs.

These are qualitative measures that will be used to assess measurement system performance for representativeness. The assessment of this qualitative criterion will be presented in the investigation report.

\subsubsection{Completeness}

Completeness is defined as generating sufficient data of the appropriate quality to satisfy the data needs identified in the DQOs. For judgmental sampling, completeness will be evaluated using both a quantitative measure and a qualitative assessment. The quantitative measurement used to evaluate completeness (Table 6-1) is based on the percentage of measurements made and judged to be valid.

For the judgmental sampling approach, the completeness goal for targeted contaminants and the remaining COPCs is 100 and 80 percent, respectively. If this goal is not achieved, the dataset will be assessed for potential impacts on making DQO decisions. For the probabilistic sampling approach, the completeness goal is a calculated minimum sample size required to produce a valid statistical comparison of the sample mean to the FAL. The methodology for determining minimum required sample size is described in Appendix C. 
The qualitative assessment of completeness is an evaluation of the sufficiency of information available to make DQO decisions. This assessment will be based on meeting the data needs identified in the DQOs and will be presented in the investigation report. Additional samples will be collected if it is determined that the number of samples do not meet completeness criteria.

\subsubsection{Comparability}

Comparability is a qualitative parameter expressing the confidence with which one dataset can be compared to another (EPA, 1987). The criteria for the evaluation of comparability will be that all sampling, handling, preparation, analysis, reporting, and data validation were performed using approved standard methods and procedures. This ensures data from this project can be compared to regulatory action levels that were developed based on data generated using the same or comparable methods and procedures. An evaluation of comparability will be presented in the investigation report.

\subsubsection{Sensitivity}

Sensitivity is the capability of a method or instrument to discriminate between measurement responses representing different levels of the variable of interest (EPA, 2001). The evaluation criteria for this parameter will be that measurement sensitivity (detection limits) will be less than or equal to the corresponding FALs. If this criterion is not achieved, the affected data will be assessed for usability and potential impacts on meeting site characterization objectives. This assessment will be presented in the investigation report. 


\subsection{Duration and Records Availability}

\subsection{Duration}

Table 7-1 is a tentative duration of activities (in calendar days) for corrective action investigation activities.

Table 7-1

Corrective Action Investigation Activity Durations

\begin{tabular}{|c|c|}
\hline $\begin{array}{c}\text { Duration } \\
\text { (days) }\end{array}$ & Activity \\
\hline \hline 10 & Site Preparation \\
\hline 76 & Field Work Preparation and Mobilization \\
\hline 55 & Sampling \\
\hline 160 & Data Assessment \\
\hline 180 & Waste Management \\
\hline
\end{tabular}

\subsection{Records Availability}

Historic information and documents referenced in this plan are retained in the NNSA/NSO project files in Las Vegas, Nevada, and can be obtained through written request to the NNSA/NSO Project Manager. This document is available in the DOE public reading rooms located in Las Vegas and Carson City, Nevada, or by contacting the appropriate DOE project manager. The NDEP maintains the official Administrative Record for all activities conducted under the auspices of the FFACO. 


\subsection{References}

ARL/SORD, see Air Resources Laboratory/Special Operations and Research Division.

ASTM, see American Society for Testing and Materials.

Air Resources Laboratory/Special Operations and Research Division. 2006. NTS Climatological Rain Gauge Data website. As accessed at http://www.sord.nv.doe/home_climate_rain.htm on 15 March.

Alderson, S., Stoller-Navarro Joint Venture. 2004. Memorandum to B. Bailey (SNJV) entitled, “Preliminary Assessments Radiological Survey 2004,” 17 February. Las Vegas, NV.

American Society for Testing and Materials. 1995. Standard Guide for Risk-Based Corrective Action Applied at Petroleum Release Sites/American Society for Testing and Materials, ASTM E 1739-95 (Reapproved 2002). Philadelphia, PA.

American Society for Testing and Materials. 2000a. Standard Test Method for Radiochemical Determination of Uranium Isotopes in Soil by Alpha Spectrometry, ASTM C 1000-00.

West Conshohocken, PA: ASTM International.

American Society for Testing and Materials. 2000b. Standard Test Method for Strontium-90 in Water, ASTM D 5811-00. West Conshohocken, PA: ASTM International.

American Society for Testing and Materials. 2002a. Standard Test Method for Isotopic Uranium in Water by Radiochemistry, ASTM D 3972-02. West Conshohocken, PA: ASTM International.

American Society for Testing and Materials. 2002b. Standard Test Method for Plutonium in Water, ASTM D 3865-02. West Conshohocken, PA: ASTM International.

American Society for Testing and Materials. 2002c. Standard Test Method for Radiochemical Determination of Plutonium in Soil by Alpha Spectroscopy, ASTM C1001-00.

West Conshohocken, PA: ASTM International.

BN, see Bechtel Nevada.

Bechtel Nevada. 1995. Nevada Test Site Performance Objective for Certification of Nonradioactive Hazardous Waste, Rev. 0, G-E11/96.01. Las Vegas, NV.

CFR, see Code of Federal Regulations.

Code of Federal Regulations. 2003a. Title 40 CFR, Parts 260-282, "Hazardous Waste Management System: General.” Washington, DC: U.S. Government Printing Office. 
Code of Federal Regulations. 2003b. Title 40 CFR, Parts 761, "Polychlorinated Biphenyls (PCBs) Manufacturing, Processing, Distribution in Commerce, and Use Prohibitions.” Washington, DC: U.S. Government Printing Office.

Code of Federal Regulations. 2003c. Title 40 CFR, Part 763, “Asbestos.” Washington, DC:

U.S. Government Printing Office.

DOE, see U.S. Department of Energy.

DOE/NV, see U.S. Department of Energy, Nevada Operations Office.

DRI, see Desert Research Institute.

Desert Research Institute. 1988. CERCLA Preliminary Assessment of DOE's Nevada Operations Office, Nuclear Weapons Testing Areas, April. Las Vegas, NV.

EPA, see U.S. Environmental Protection Agency.

EG\&G Rocky Flats. 1991. General Radiochemistry and Routine Analytical Services Protocol (GRASP), Version 2.1, July. Golden, CO: Environmental Management Department.

ERDA, see U.S. Energy Research and Development Administration.

FFACO, see Federal Facility Agreement and Consent Order.

Federal Facility Agreement and Consent Order. 1996 (as amended). Agreed to by the State of Nevada, the U.S. Department of Energy, and the U.S. Department of Defense.

Moore, J., Science Applications International Corporation. 1999. Memorandum to M. Todd (SAIC) entitled, “Background Concentrations for NTS and TTR Soils Samples,” 3 February. Las Vegas, NV: IT Corporation.

Murphy, T., Bureau of Federal Facilities. 2004. Letter to R. Bangerter (NNSA/NSO) entitled, "Review of Industrial Sites Project Document Guidance for Calculating Industrial Sites Project Remediation Goals for Radionuclides in Soil Using the Residual Radiation (RESRAD) Computer Code.” 19 November. Las Vegas, NV.

NAC, see Nevada Administrative Code.

NBMG, see Nevada Bureau of Mines and Geology.

NCRP, see National Council on Radiation Protection and Measurements.

NDEP, see Nevada Division of Environmental Protection. 
NNSA/NSO, see U.S. Department of Energy, National Nuclear Security Administration Nevada Site Office.

NNSA/NV, see U.S. Department of Energy, National Nuclear Security Administration Nevada Operations Office.

NRS, see Nevada Revised Statutes.

National Council on Radiation Protection and Measurements. 1999. Recommended Screening Limits for Contaminated Surface Soil and Review of Factors Relevant to Site-Specific Studies/National Council on Radiation Protection and Measurements, NCRP Report No. 129. Bethesda, MD.

Nevada Administrative Code. 2004. NAC 444, "Sanitation.” Carson City, NV. As accessed at http://www.leg.state.nv.us/nac on 30 March 2006.

Nevada Administrative Code. 2005. NAC 445A, “Water Controls.” Carson City, NV. As accessed at http://www.leg.state.nv.us/nac on 30 March 2006.

Nevada Bureau of Mines and Geology. 1998. Mineral and Energy Resource Assessment of the Nellis Air Force Range, Open-File Report 98-1. Reno, NV.

Nevada Division of Environmental Protection. 1995. Mutual Consent Agreement between the State of Nevada and the U.S. Department of Energy for the Storage of Low-Level Land Disposal Restricted Mixed Waste. Carson City, NV.

Nevada Division of Environmental Protection. 1997a. Class II Solid Waste Disposal Site for Municipal and Solid Waste, Area 23 of the NTS, Permit SW 13-097-04. Carson City, NV.

Nevada Division of Environmental Protection. 1997b (as amended in August 2000). Class III Solid Waste Disposal Site for Hydrocarbon Burdened Soils, Area 6 of the NTS, Permit SW 1309702. Carson City, NV.

Nevada Division of Environmental Protection. 1997c (as amended in August 2000). Class III Solid Waste Disposal Site; UIOC, Area 9 of the NTS, Permit SW 13-097-03. Carson City, NV.

Nevada Division of Environmental Protection. 1999. State of Nevada Water Pollution Control General Permit, No. GNEV93001. Carson City, NV.

Nevada Division of Environmental Protection. 2005. Nevada Test Site Permit for Hazardous Waste Management Facility (NEV HW0021). November. Las Vegas, NV.

Nevada Revised Statutes. 2005a. NRS 444.440 - 444.620, “Collection and Disposal of Solid Waste.” Carson City, NV. 
Nevada Revised Statutes. 2005b. NRS 459.400 - 459.600, "Disposal of Hazardous Waste.” Carson City, NV.

Nevada Revised Statutes. 2005c. NRS 618.750 - 618.840 “Disposal of Hazardous Waste.” Carson City, NV.

Nicosia, W., Stoller-Navarro Joint Venture. 2004. Memorandum to B. Bailey (SNJV) entitled, "Radiological land Area Surveys of Corrective Action Unit (CAU) 166: Area 2 Storage Yards and Contaminated Materials (Corrective Action Sites [CASs] 02-42-02 and 02-99-10) at the Nevada Test Site,” 17 November. Las Vegas, NV.

Nicosia, W., Stoller-Navarro Joint Venture. 2006. Email to B. Bailey (SNJV) entitled, “CAU 166 Rad Surveys,” 6 April. Las Vegas, NV.

Paar, J.G., and D.R. Porterfield. 1997. Evaluation of Radiochemical Data Usability, April, ES/ER/MS-5. Oak Ridge, TN: U.S. Department of Energy.

SNJV, see Stoller-Navarro Joint Venture.

Shott, G.J., V. Yucel, M.J. Sully, L.E. Barker, S.E. Rawlinson, and B.A. Moore. 1997. Performance Assessment/Composite Analysis for the Area 3 Radioactive Waste Management Site at the Nevada Test Site, Nye County, Nevada, Rev. 2.0. Las Vegas, NV.

Stoller-Navarro Joint Venture. 2004. Industrial Sites Project Health and Safety Plan, Rev. 0. Las Vegas, NV.

Stoller-Navarro Joint Venture. 2005. Project Execution Plan, Rev. 0. Las Vegas, NV.

USC, see United State Code.

USGS, see U.S. Geological Survey.

United States Code. 1976. 15 USC 2601 et seq., “Toxic Substances Control Act.” Enacted by Public Law No. 94-469, as amended. Washington, DC: U.S. Government Printing Office.

U.S. Department of Energy. 1993. Radiation Protection of the Public and the Environment, DOE Order 5400.5, Change. 2. Washington, DC: U.S. Government Printing Office.

U.S. Department of Energy. 1997. The Procedures Manual of the Environmental Measurements Laboratory, HASL-300, 28th Ed., Vol. I. New York, NY.

U.S. Department of Energy, National Nuclear Security Administration Nevada Operations Office. 2002a. Industrial Sites Quality Assurance Project Plan, Nevada Test Site, Nevada, Rev. 3, DOE/NV--372. Las Vegas, NV. 
U.S. Department of Energy, National Nuclear Security Administration Nevada Operations Office. 2002b. Underground Test Area Project Waste Management Plan, Rev. 2, DOE/NV--343. Las Vegas, NV.

U.S. Department of Energy, National Nuclear Security Administration Nevada Site Office. 2004. NV/YMP Radiological Control Manual, Rev. 5, DOE/NV/11718-079, UC-702. Prepared by A.L. Gile of Bechtel Nevada. Las Vegas, NV.

U.S. Department of Energy, National Nuclear Security Administration Nevada Site Office. 2005. Nevada Test Site Waste Acceptance Criteria, DOE/NV--325, Rev. 6. Las Vegas, NV.

U.S. Department of Energy, National Nuclear Security Administration Nevada Site Office. 2006. Industrial Sites Project Establishment of Final Action Levels, Rev. 0, DOE/NV--1107. Prepared by Stoller-Navarro Joint Venture. Las Vegas, NV.

U.S. Department of Energy, Nevada Operations Office. 1992. Remedial Investigation and Feasibility Study for the Plutonium Contaminated Soils at Nevada Test Site, Nellis Air Force Range and Tonopah Test Range, April. Las Vegas, NV.

U.S. Department of Energy, Nevada Operation Office. 1996. Final Environmental Impact Statement for the Nevada Test Site and Off-Site Locations in the State of Nevada, DOE/EIS 0243. Las Vegas, NV.

U.S. Department of Energy, Nevada Operations Office. 1997a. Analysis of Fractures in Volcanic Cores from Pahute Mesa, Nevada Test Site, September, DOE/NV/11718-160. Las Vegas, NV.

U.S. Department of Energy, Nevada Operations Office. 1997b. Integrated Safety Management Policy, DOE Order NV P 450.4. Las Vegas, NV.

U.S. Department of Energy, Nevada Operations Office. 1998. Nevada Test Site Resource Management Plan. DOE/NV--518, Las Vegas, NV.

U.S. Department of Energy, Nevada Operations Office. 1999. Resource Conservation and Recovery Act, Part B, Permit Application for Waste Management Activities at the Nevada Test Site. Las Vegas, NV.

U.S. Energy Research and Development Administration. 1977. Final Environmental Impact Statement, Nevada Test Site, Nye County, Nevada, ERDA-1551, Washington, DC.

U.S. Environmental Protection Agency. 1987. Data Quality Objectives for Remedial Response Activities, EPA/540/G-87/003. Washington, DC.

U.S. Environmental Protection Agency. 1988a. Contract Laboratory Program Statement of Work for Inorganic Analysis, SOW No. 788, EPA/540/R-94/093. Washington, DC. 
U.S. Environmental Protection Agency. 1988b. Contract Laboratory Program Statement of Work for Organic Analysis, SOW No. 2/88, EPA/540/R-94/096. Washington, DC.

U.S. Environmental Protection Agency. 1991. Contract Laboratory Program Statement of Work for Organic Analysis, OLMO 1.8, EPA/540/R-94/078. Washington, DC.

U.S. Environmental Protection Agency. 1994a. Contract Laboratory Program National Functional Guidelines for Inorganic Data Review, EPA/540/R-94/013. Washington, DC.

U.S. Environmental Protection Agency. 1994b. Contract Laboratory Program Statement of Work for Inorganic Analysis, ILMO 3.0, EPA/540/R-94/076. Washington, DC.

U.S. Environmental Protection Agency. 1994c. Contract Laboratory Program Statement of Work for Organic Analysis, OLMO 3.1, EPA/540/R-94/073. Washington, DC.

U.S. Environmental Protection Agency. 1996. Test Methods for Evaluating Solid Waste Physical/Chemical Methods, SW-846, 3rd Edition. Washington, DC.

U.S. Environmental Protection Agency. 2001. Guidance on Data Quality Indicators, EPA QA/G-5i. Washington, DC.

U.S. Environmental Protection Agency. 2004. Region 9 Preliminary Remediation Goals (PRGs). As accessed at http://www.epa.gov/region09/waste/sfund/prg/index.htm on 30 March 2006. Prepared by S.J. Smucker. San Francisco, CA.

U.S Geological Survey. 1990. Geologic Map of the Nevada Test Site, Southern Nevada. USGS Map I-2046. Denver, CO.

U.S Geological Survey. 1996. Summary of Hydrogeological Controls on Groundwater Flow at the Nevada Test Site, Nye County, Nevada, USGS WRIR 96-4109. Prepared by R.J. Laczniak, J.C. Cole, D.A. Sawyer, and D.A. Trudeau.

U.S Geological Survey and U.S. Department of Energy. 2006. "Water Levels.” As accessed at http://nevada.usgs.gov/doe_nv/ on 20 March.

Winograd, I.J., and W. Thordarson. 1975. Hydrology and Hydrochemical Framework, South-Central Great Basin, Nevada-California, with Special Reference to the Nevada Test Site, USGS Professional Paper 712-C. Denver, CO. 


\section{Appendix A}

\section{Data Quality Objectives}




\section{A.1.0 Introduction}

The DQO process described in this appendix is a seven-step strategic systematic planning method based on the scientific method that was used to plan data collection activities and define performance criteria for the CAU 166, Storage Yards and Contaminated Materials field investigation. The DQOs are designed to ensure that the data collected will provide sufficient and reliable information to identify, evaluate, and technically defend recommended corrective actions (i.e., no further action, closure in place, or clean closure). Existing information about the nature and extent of contamination at the CASs in CAU 166 is insufficient to evaluate and select preferred corrective actions; therefore, CAI will be conducted.

The CAU 166 investigation will be based on the DQOs presented in this appendix as developed by representatives of the NDEP and the NNSA/NSO. The seven steps of the DQO process presented in Sections A.3.0 through A.9.0 were developed in accordance with EPA Guidance for the Data Quality Objectives Process (EPA, 2000b) and EPA Guidance for Quality Assurance Project Plans (EPA, 2002). The DQO process presented herein is based on the EPA Quality System Document for DQOs entitled Data Quality Objectives Process for Hazardous Waste Site Investigations (EPA, 2000a), and the CAS-specific information presented in Section A.2.0.

The DQO process presents a combination of judgmental and probabilistic sampling approaches. In general, the procedures used in the DQO process provide:

- A scientific basis for making inferences about a site (or portion of a site) based on environmental data or process knowledge.

- A basis for defining decision performance criteria and assessing the achieved decision quality of the data collection design.

- Criteria for knowing when site investigators should stop data collection (i.e., when sufficient information is available to support decisions).

- A basis for demonstrating an acceptable level of confidence in the sampling approach to generate the appropriate quantity and quality of information necessary to minimize the potential for making decision errors. 


\section{A.2.0 Background Information}

The following 7 CASs that comprise CAU 166 are located in NTS Areas 2, 3, 5, and 18, as shown in Figure A.2-1:

- CAS 02-42-01, Cond. Release Storage Yd - North

- CAS 02-42-02, Cond. Release Storage Yd - South

- CAS 02-99-10, D-38 Storage Area

- CAS 03-42-01, Conditional Release Storage Yard

- CAS 05-19-02, Contaminated Soil and Drum

- CAS 18-01-01, Aboveground Storage Tank

- CAS 18-99-03, Wax Piles/Oil Stain

The following sections (Sections A.2.1 through A.2.3) provide a CAS description, physical setting and operational history, release information, and previous investigation results for each CAS in CAU 166. The CAS-specific COPCs are provided in the following sections. Many of the COPCs are based on a conservative evaluation of possible site activities considering the incomplete site histories of the CASs and considering contaminants found at similar NTS sites. Targeted contaminants are defined as those contaminants that are known or that could be reasonably suspected to be present within the CAS based on previous sampling or process knowledge.

\section{A.2.1 Corrective Action Site 02-42-01, Cond. Release Storage Yd - North}

Corrective Action Site 02-42-01 consists of potential releases of contaminants to the soil in the yard from various machinery and equipment that were stored at the site. The storage yard is located northeast of the intersection of Rainier Mesa and 2-07 Roads in the Area 2 Camp. Figure A.2-2 shows a site sketch of the CAS.

Physical Setting - CAS 02-42-01 is located on Yucca Flat in Area 2. The average annual precipitation for the area, as measured at Station UCC located approximately $14.5 \mathrm{mi}$ south of CAS 02-42-01 on Yucca Flat dry lake, is 6.62 in. per year (ARL/SORD, 2005). Vegetations consists of sparsely distributed brush. The surrounding undisturbed soil consists of mostly fine soil particles, but includes some coarse, pebble sized rock. The thickness of the local alluvium layer is unknown. The area is relatively flat with no nearby drainage channels. The USGS WW-2 well is located 


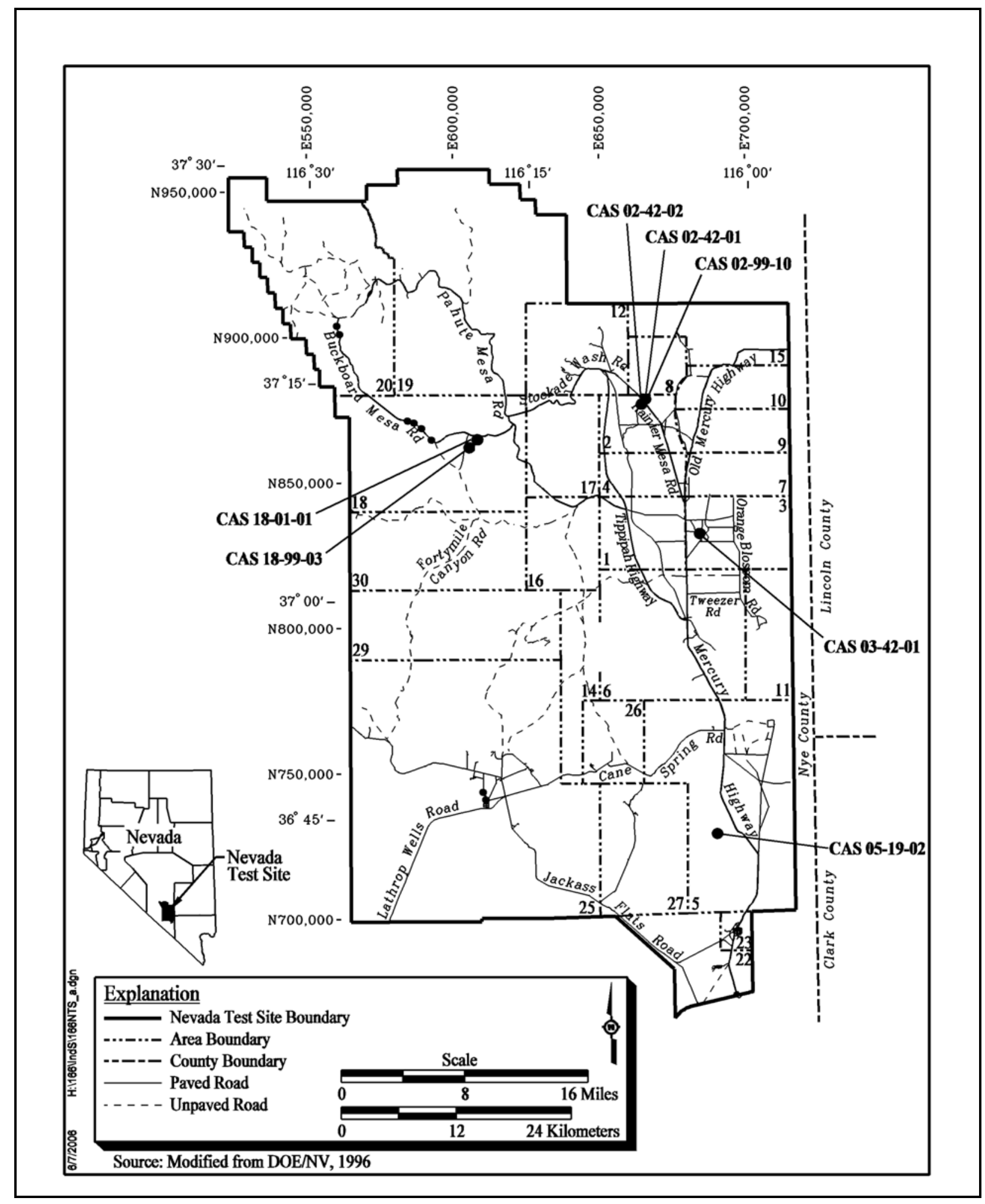

Figure A.2-1

Corrective Action Unit 166, CAS Location Map 


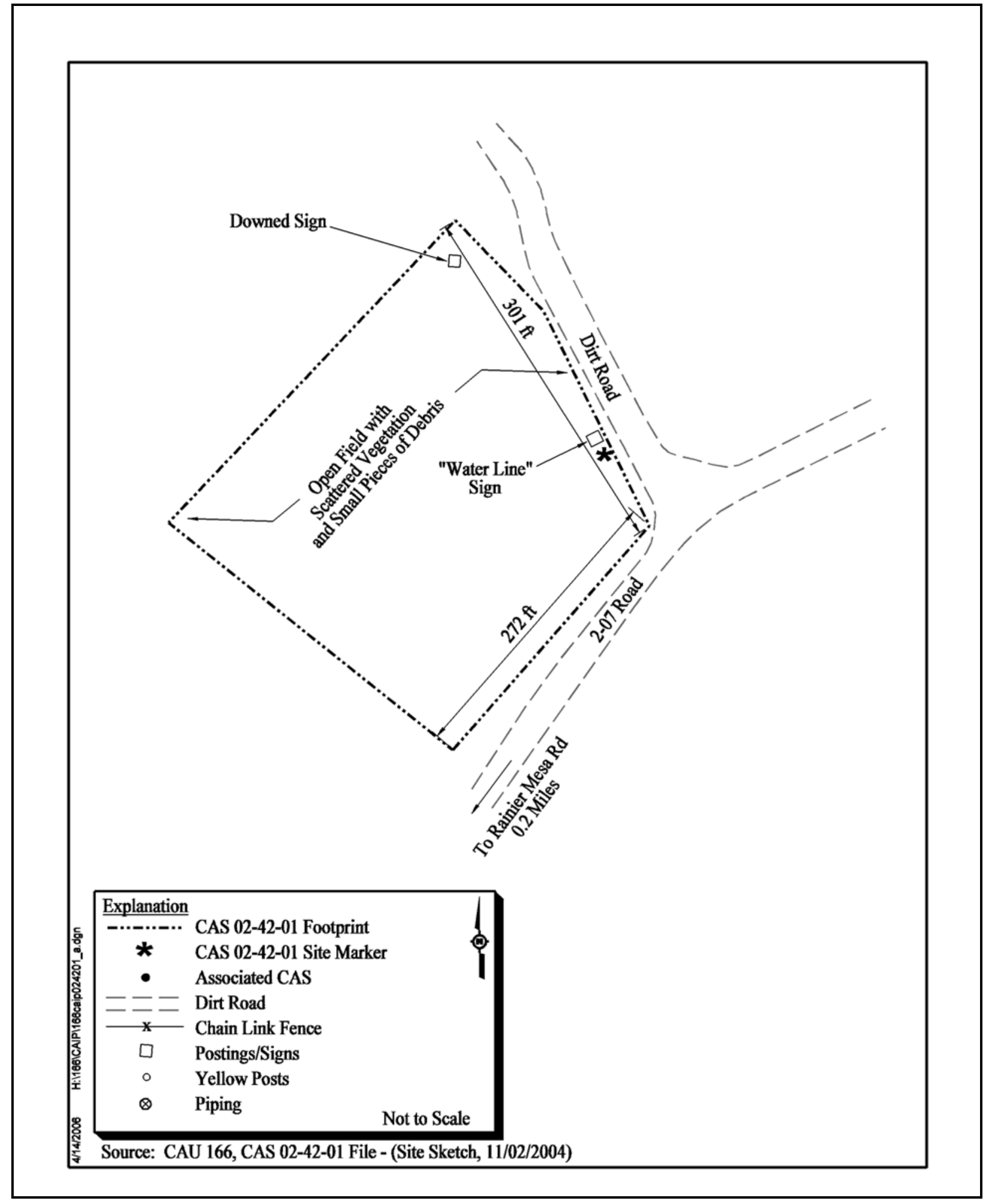

Figure A.2-2

Site Sketch of CAS 02-42-01, Cond. Release Storage Yd - North 
3,640 ft northeast of the CAS. The depth to groundwater on September 21, 2005 was measured at 2,052 ft bgs (USGS/DOE, 2006).

Operational History - The storage yard was used to store equipment and piping associated with LLNL construction and drilling operations in the Yucca Flat area. The storage yard was previously posted “Caution - Possible Inaccessible and/or Fixed Radioactive Contamination Present.” However, the postings along with the former equipment were removed prior to 2001.

Release Information - There is the potential that contaminants were released to the soil because equipment associated with underground nuclear testing was stored at this site. Although staining is not currently visible, radioisotopes, hydrocarbons, and metals may have been released to the soil from equipment stored at the site.

Previous Investigation Results - Previous investigations of CAS 02-42-01 include site visits and a radiological survey. There is debris at the site including pieces of metal, wire, cable, wood, plastic, and broken glass. Other than small pieces of drill pipe, there is no evidence of the material that was once stored at this yard. There is nothing to suggest that there is buried material at this site. The yard measures aproximately 272 by $301 \mathrm{ft}$. The area appears to have been previously graded but vegetation has regrown in the yard. There are overhead power lines approximately $100 \mathrm{ft}$ north of the site. According to the radiological survey, gamma radiation is at or near background at this site. Therefore, the site does not pose a risk to individuals from residual radiological contamination when performing non-intrusive activities (Nicosia, 2006). There are no known sampling results from this site.

\section{A.2.2 Corrective Action Site 02-42-02, Cond. Release Storage Yd - South}

Corrective Action Site 02-42-02 consists of potential release of contaminants to the soil in the storage yard from various machinery and equipment that were stored at the site. The storage yard is located southwest of the intersection of Rainier Mesa and 2-07 Roads in the Area 2 Camp. Figure A.2-3 shows a site sketch of the CAS.

Physical Setting - CAS 02-42-02 is located on Yucca Flat in Area 2. The average annual precipitation for the area, as measured at Station UCC located approximately $14.5 \mathrm{mi}$ south of 


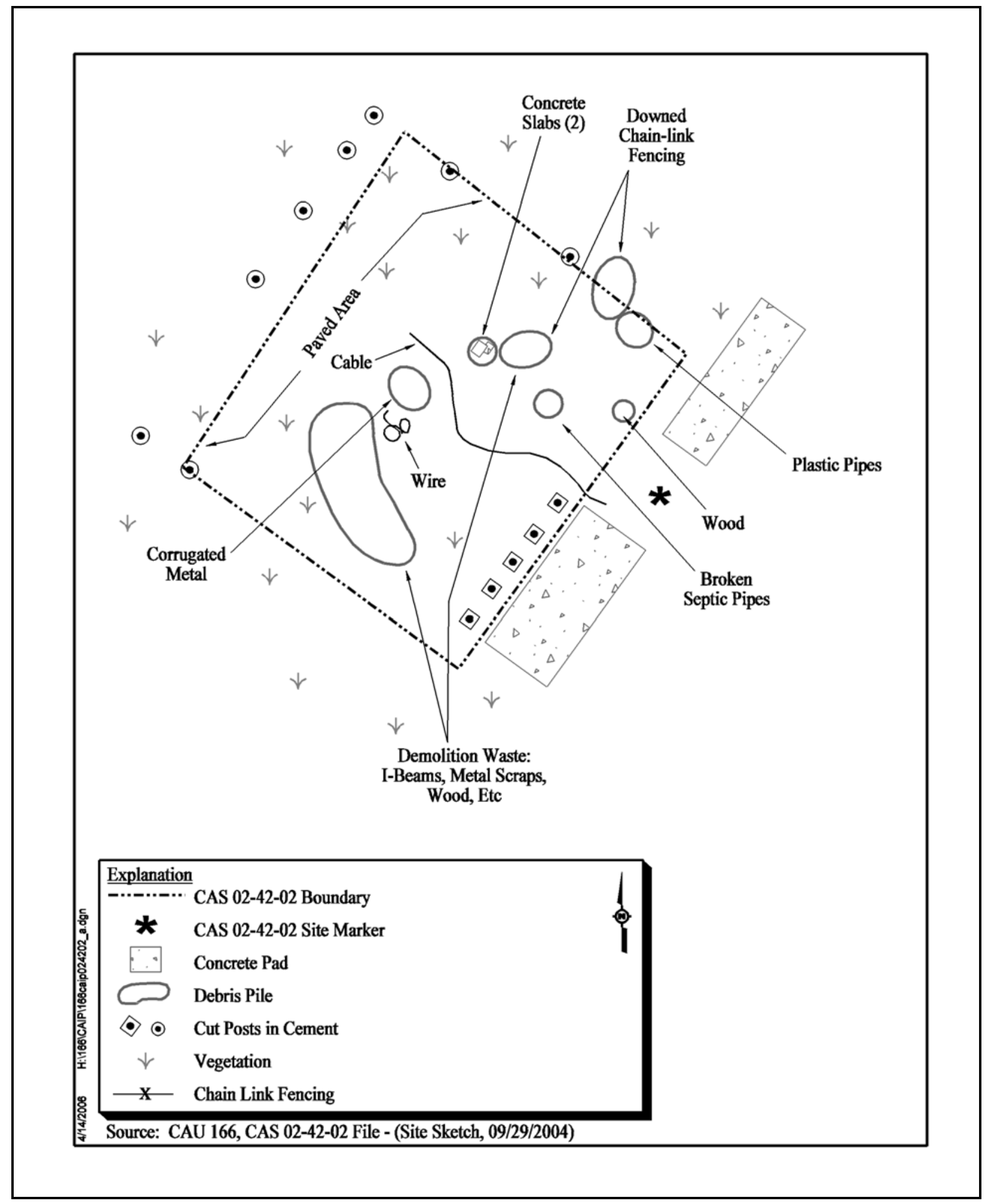

Figure A.2-3

Site Sketch of CAS 02-42-02, Cond. Release Storage Yd - South 
CAS 02-42-02 on Yucca Flat dry lake, is 6.62 in. per year (ARL/SORD, 2005). Vegetation consists of sparsely distributed brush. The surrounding undisturbed soil consists of mostly fine soil particles, but includes some coarse, pebble sized rock. The thickness of the local alluvium layer is unknown.

The area is relatively flat with no nearby drainage channels. The USGS WW-2 well is located 4,750 ft northeast of the CAS. The depth to groundwater on September 21, 2005, was measured at 2,052 ft bgs (USGS/DOE, 2006).

Operational History - The storage yard was used to store equipment and piping associated with LLNL construction and drilling operations in the Yucca Flat area. It has been speculated that gas sampling tanks may have been temporarily stored at this site. The former equipment and/or tanks were removed prior to 1995 . The storage yard was previously posted “Caution - Possible Inaccessible and/or Fixed Radioactive Contamination Present.” However, the postings along with the former equipment was removed.

Release Information - There is the potential that contaminants were released to the soil because equipment and gas sampling tanks associated with underground testing were stored at this site. Although staining is not currently visible, radioisotopes, hydrocarbons, and metals may have been released to the soil from equipment stored at the site.

Previous Investigation Results - Previous investigations of CAS 02-42-02 include site visits and a radiological survey. There is various debris at the site including demolition debris (I-beams, wood, corrugated metal, etc.), chain-link fencing, cables, concrete slabs, and broken septic and PVC piping. There is nothing to suggest that there is buried material at this site. The yard measures aproximately 167 by $193 \mathrm{ft}$. The area appears to have been previously graded and covered with imported gravel but vegetation has regrown in the yard. According to the radiological survey, gamma radiation is at or near background at this site. Therefore, the site does not pose a risk to individuals from residual radiological contamination when performing non-intrusive activities (Nicosia, 2004). There are no known sampling results from this site. 


\section{A.2.3 Corrective Action Site 02-99-10, D-38 Storage Area}

Corrective Action Site 02-99-10 consists of potential release of contaminants to the soil in the storage yard from various machinery, equipment, and drums containing depleted uranium that were stored at the site. The storage yard is located southeast of the intersection of Rainier Mesa and 2-07 Roads in the Area 2 Camp. Figure A.2-4 shows a site sketch of the CAS.

Physical Setting - CAS 02-99-10 is located on Yucca Flat in Area 2. The average annual precipitation for the area, as measured at Station UCC located approximately $14.5 \mathrm{mi}$ south of CAS 02-99-10 on Yucca Flat dry lake, is 6.62 in. per year (ARL/SORD, 2005). Vegetation consists of sparsely distributed brush. The surrounding undisturbed soil consists of mostly fine soil particles, but includes some coarse, pebble-sized rock. The thickness of the local alluvium layer is unknown. The area is relatively flat with no nearby drainage channels. The USGS WW-2 well is located $3,280 \mathrm{ft}$ northeast of the CAS. The depth to groundwater on September 21, 2005, was measured at 2,052 ft bgs (USGS/DOE, 2006).

Operational History - The storage yard was used to store various equipment associated with LLNL construction and drilling operations in the Yucca Flat area. Additionally, a portion of the yard was used to store approximately 190 drums containing depleted uranium. The depleted uranium was stored in the drums and used as counterweights of large cranes used in Project Heavyweight. When the project was over, the drums containing solid depleted uranium were stored at CAS 02-99-10 until the material was repackaged and properly disposed. The storage yard was previously posted “Caution Radioactive Contamination Area” and "Caution Radioactive Material.” However, the postings along with the drums and equipment have been removed.

Release Information - There is the potential that radioisotopes were released to the soil since drilling equipment associated with underground testing and drums containing depleted uranium were previously stored at this site. Additionally, although staining is not currently visible, hydrocarbons and metals may have been released to the soil from equipment stored at the site. A separate release may be present within the storage yard as a result of discharge from a french drain that is adjacent to the yard. This potential release is being investigated for potential inclusion in the FFACO; therefore, any contamination found associated with the french drain will not be covered in this CAIP. 


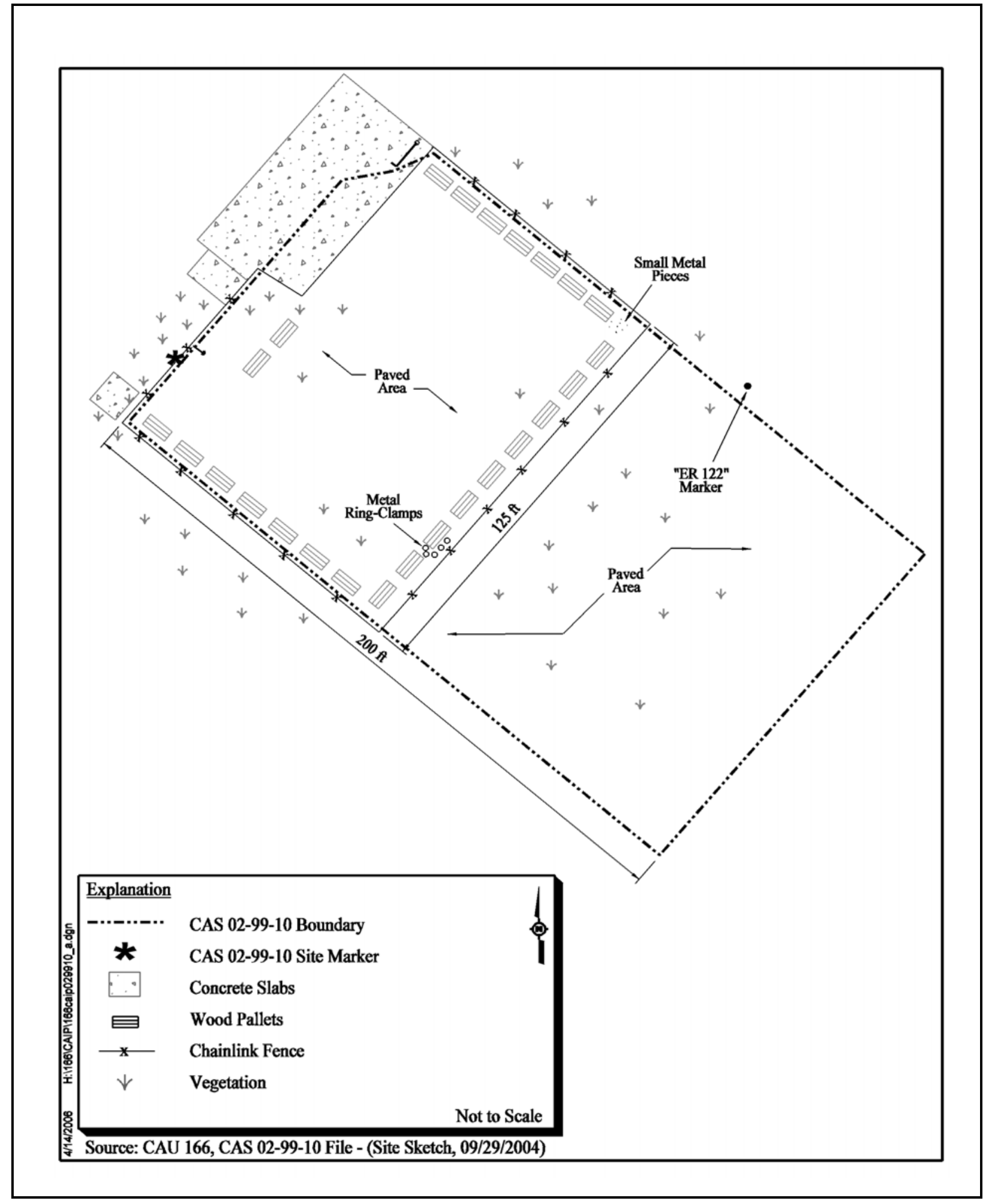

Figure A.2-4

Site Sketch of CAS 02-99-10, D-38 Storage Area 
Previous Investigation Results - Previous investigations of CAS 02-99-10 include sites visits and a radiological survey. There is various debris at the site such as metal drum clamps, cables, and wooden pallets that once held the drums. There is some staining on the pallets that resembles rust. There was no soil staining observed and there is nothing to suggest that there is buried material at this site. The yard is rectangular and fenced, measuring aproximately 200 by $125 \mathrm{ft}$. The area appears to have been previously graded, paved, and covered with imported gravel but the paving has begun to deteriorate. According to the radiological survey, gamma radiation is at or near background at this site. Therefore, the site does not pose a risk to individuals from residual radiological contamination when performing non-intrusive activities (Nicosia, 2004). There are no known sampling results from this site.

\section{A.2.4 Corrective Action Site 03-42-01, Conditional Release Storage Yard}

Corrective Action Site 03-42-01 consists of potential release of contaminants to the soil in the storage yard from various machinery and equipment that were stored at the site. The storage yard is located south of the Postshot Shop in the Area 3 Camp. Figures A.2-5 and A.2-6 are site sketches of this CAS.

Physical Setting - CAS 03-42-01 is located on Yucca Flat in Area 3. The average annual precipitation for the area, as measured at the Area 3 Camp, is $6.31 \mathrm{in}$. per year (ARL/SORD, 2005). Vegetation consists of sparsely distributed brush. The surrounding undisturbed soil consists of mostly fine soil particles, but includes some coarse, pebble-sized rock. The thickness of the local alluvium layer is unknown. The USGS Water Well A is located approximately $500 \mathrm{ft}$ north of the CAS. The depth to groundwater on September 21, 2005, was measured at 1,600 ft bgs (USGS/DOE, 2006).

Operational History - The storage yard was used to store machinery, equipment, and piping associated with LANL construction and drilling operations in the Yucca Flat area (Figure A.2-7). The useable equipment was relocated after 1993; however, there are numerous items remaining in the yard. The northwest corner of the storage yard is posted "Caution Radioactive Material.”

Release Information - There is the potential that contaminants were released to the soil from equipment, tanks, portable buildings, and other miscellaneous equipment/objects associated with 


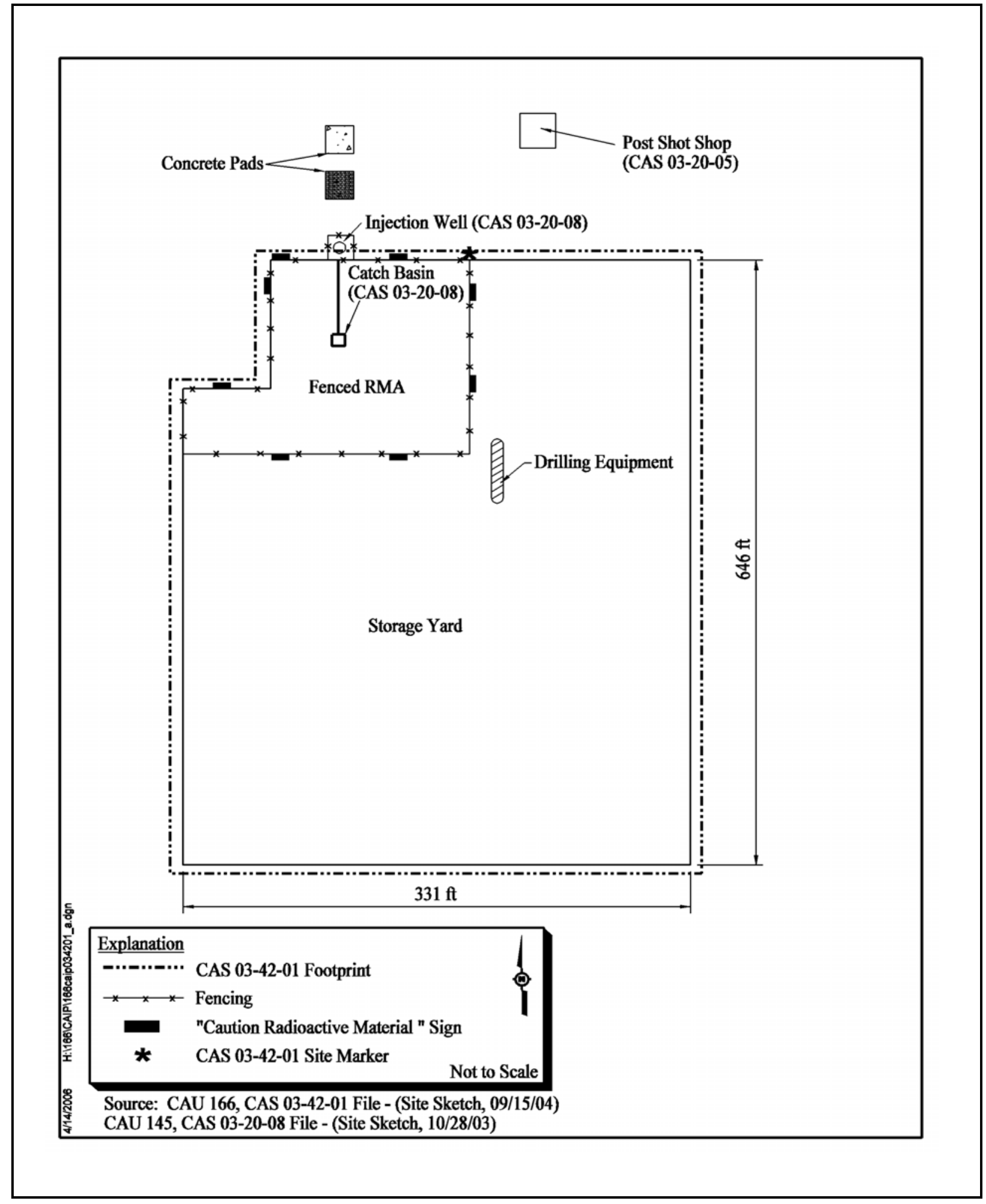

Figure A.2-5

Site Sketch of CAS 03-42-01, Conditional Release Storage Yard 


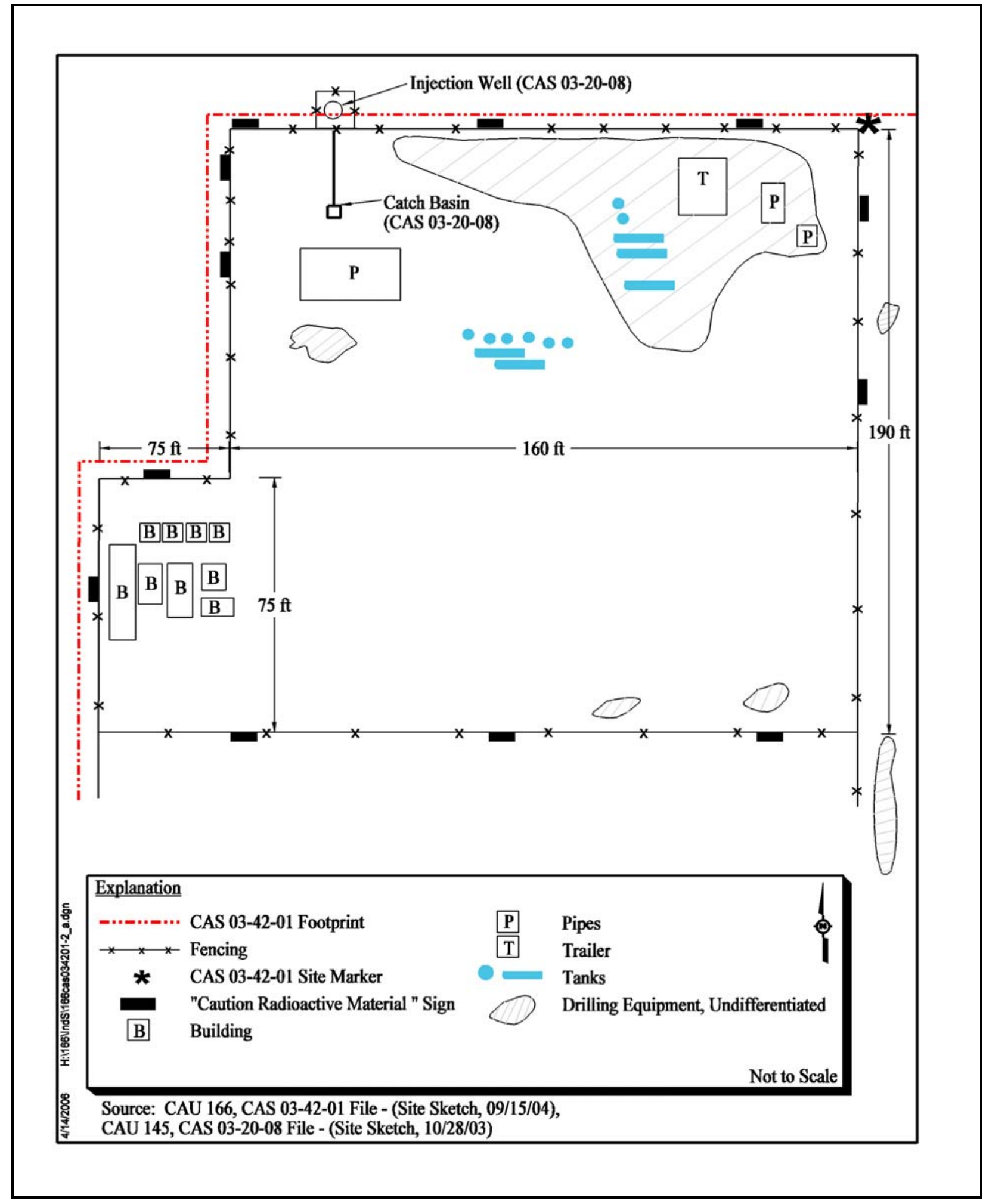

Figure A.2-6

Site Sketch of Radioactive Material Area in CAS 03-42-01, Conditional Release Storage Yard 


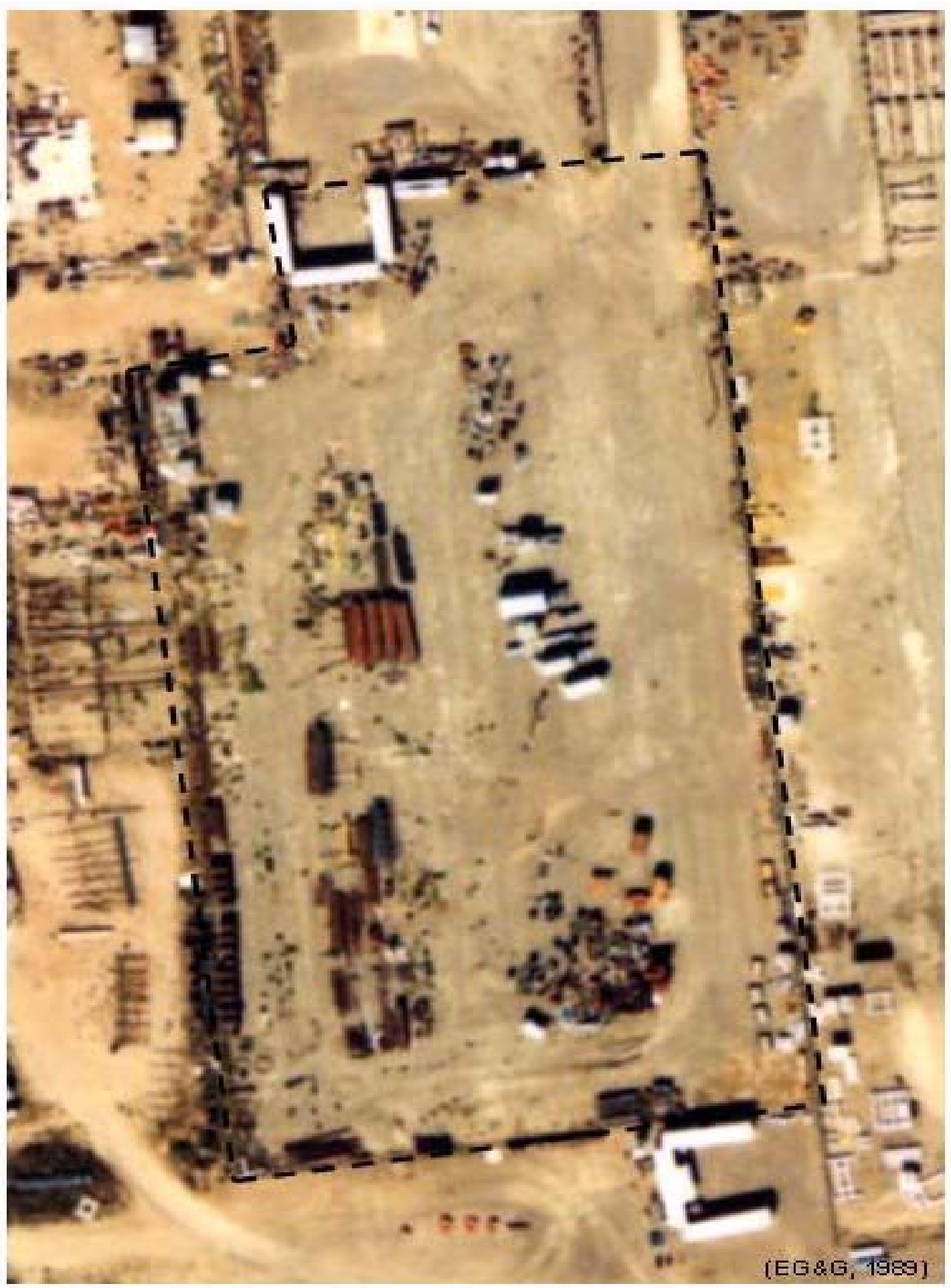

Figure A.2-7

Historical Photograph of CAS 03-42-01,

Conditional Release Storage Yard 
underground testing that were stored at this site. There is visible staining in many of the areas within the posted radioactive material area where equipment was and continues to be stored. There is no visible staining in the unposted area of the storage yard. However, radioisotopes, hydrocarbons, and metals may have been released to the soil from equipment stored in both portions of the storage yard. CAU 145, CAS 03-20-08, Injection Well is also located within the posted area of the storage yard. The site consists of several components outside of the fenced yard and a catch basin and piping that is located within the storage yard. A decontamination pad located just outside the posted area discharged effluent to the injection well and catch basin.

Previous Investigation Results - Previous investigations of CAS 03-42-01 include site visits, radiological surveys, and sampling of adjacent CASs. There are portable buildings, heavy equipment, tanks, piping, and miscellaneous debris present in the storage yard. The northwest corner of the storage yard is fenced and posted. The majority of the equipment, tanks, and buildings are stored in this posted area. Figures A.2-8 and A.2-9 are photographs of some of the material still present in this portion of the yard. There is nothing to suggest that there is buried material at this site. The fenced yard is nearly square, measuring aproximately 646 by $331 \mathrm{ft}$. The storage yard is paved with some areas of minor deterioration. According to radiological surveys completed in both portions of the storage yard, the gamma radiation is at or near background. No removable contamination was encountered, so the site will not require radiological support for future activities (Alderson, 2004; Nicosia, 2006). Diesel-range organics were detected at a level of $500 \mathrm{mg} / \mathrm{kg}$ in a sample taken adjacent to the CAS 03-20-08 former catch basin. The sample was taken at an interval of 5 to $6 \mathrm{ft}$ bgs, approximately $5 \mathrm{ft}$ west of the former catch basin ( $25 \mathrm{ft}$ from its center). This contaminant is most likely a result of activities that took place in the storage yard.

\section{A.2.5 Corrective Action Site 05-19-02, Contaminated Soil and Drum}

Corrective Action Site 05-19-02 consists of potential release of contaminants to the soil from vehicles and materials within the storage yard, drums stored adjacent to the storage yard, and the drum in the wash. The storage yard and drum are located approximately 1.4 miles west of Mercury Highway in Area 5. The site includes a fenced storage yard along with a contiguous area outside of the fenced yard where drums were stored. Additionally, a drum is located in an active wash, approximately 


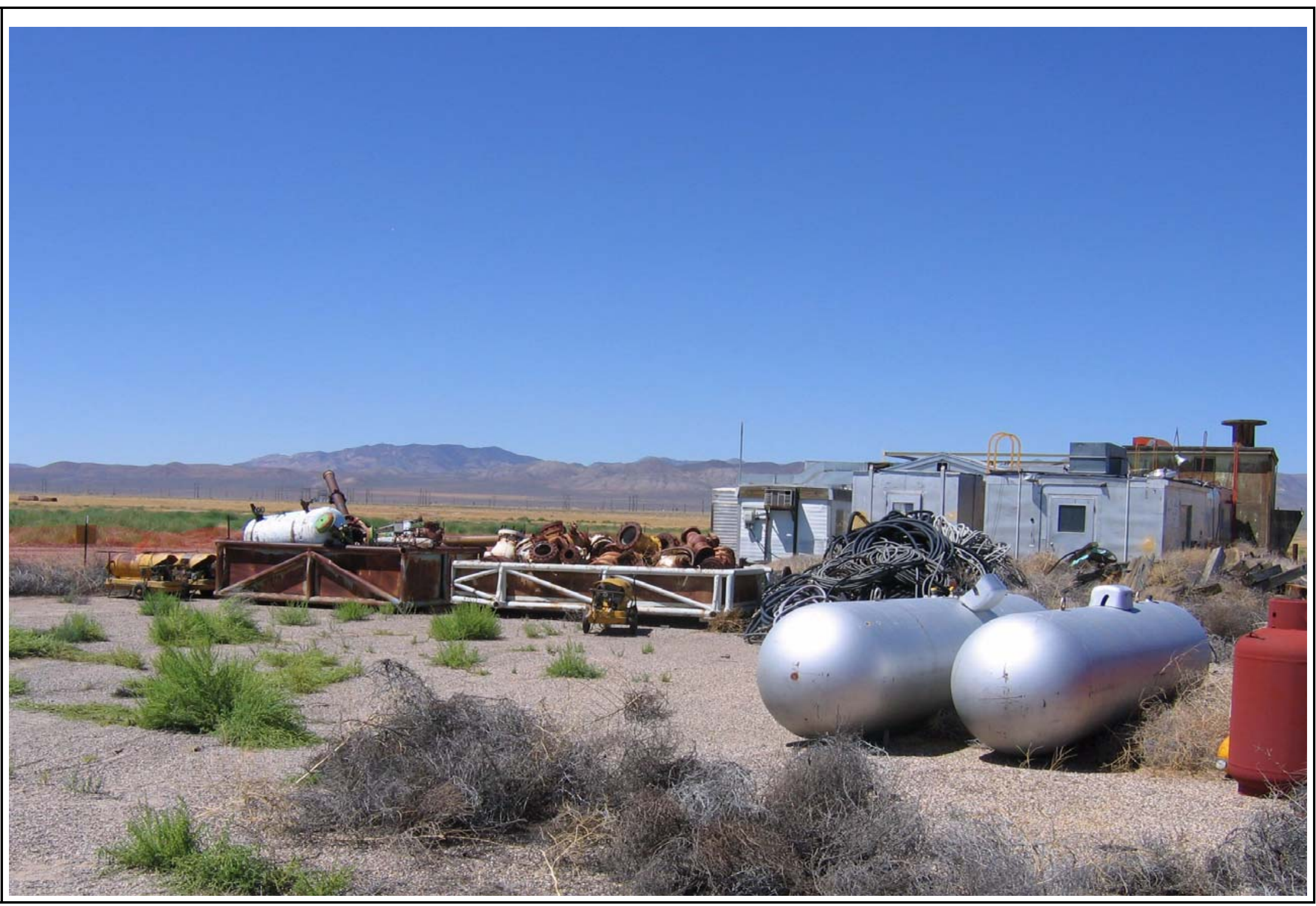

Figure A.2-8

Material Remaining in CAS 03-42-01, Conditional Release Storage Yard 




Figure A.2-9

Material Remaining in CAS 03-42-01, Conditional Release Storage Yard 
$126 \mathrm{ft}$ east of the yard and an area of drum remnants is present outside of the fenced yard. Figure A.2-10 shows a site sketch of the CAS.

Physical Setting - CAS 05-19-02 is located on Frenchman Flat in Area 5. The average annual precipitation for the area, as measured at the station Cane Springs, is 7.49 in. per year (ARL/SORD, 2005). Vegetations consists of sparsely distributed brush. The surrounding undisturbed soil consists of very fine soil particles. The thickness of the local alluvium layer is unknown; however, Test Hole \#5, located approximately 1 mi north of CAS 05-19-02, penetrated approximately 1,300 ft of alluvium (USGS, 1967). The area is relatively flat with a nearby drainage channel. The USGS WW-5A is located approximately $3.7 \mathrm{mi}$ northeast of the CAS. The depth to groundwater on September 1, 2005, was measured at $709 \mathrm{ft}$ bgs (USGS/DOE, 2006).

Operational History - Vehicles and steel were stored in the fenced yard to permit induced radioactivity to decay out. Additional items may have been stored in the yard but have since been removed. The vehicles and steel have been determined to have historical significance. These vehicles are not part of the CAS 05-19-02 work scope.

There were 17 drums stored in the area adjacent to the fenced yard. Although documentation states that the drums were removed in 1991 (along with three car batteries), one drum is visible in the wash located to the east of the storage yard. According to notes from a site visit in 1990, many of the drums were rusted through and the contents had solidified (REECo, 1991). An area of drum remnants was identified on the outside of the southeastern portion of the yard. This is not in the area of the identified drum storage location.

Release Information - There is the potential that contaminants were released to the soil from the vehicles, steel, and drums stored at this site. Radioisotopes, hydrocarbons, and metals may have been released to the soil if there was leaking from the vehicles, materials, or drums stored at the site.

Previous Investigation Results - Previous investigations of CAS 05-19-02 include site visits, a radiological survey, and a geophysical survey. Vehicles and steel remain at the site although they are not part of the CAS 05-19-02 work scope. There is additional debris at the site including wood and metal pieces that have rusted off of the vehicles or were from items previously stored in the yard. The 


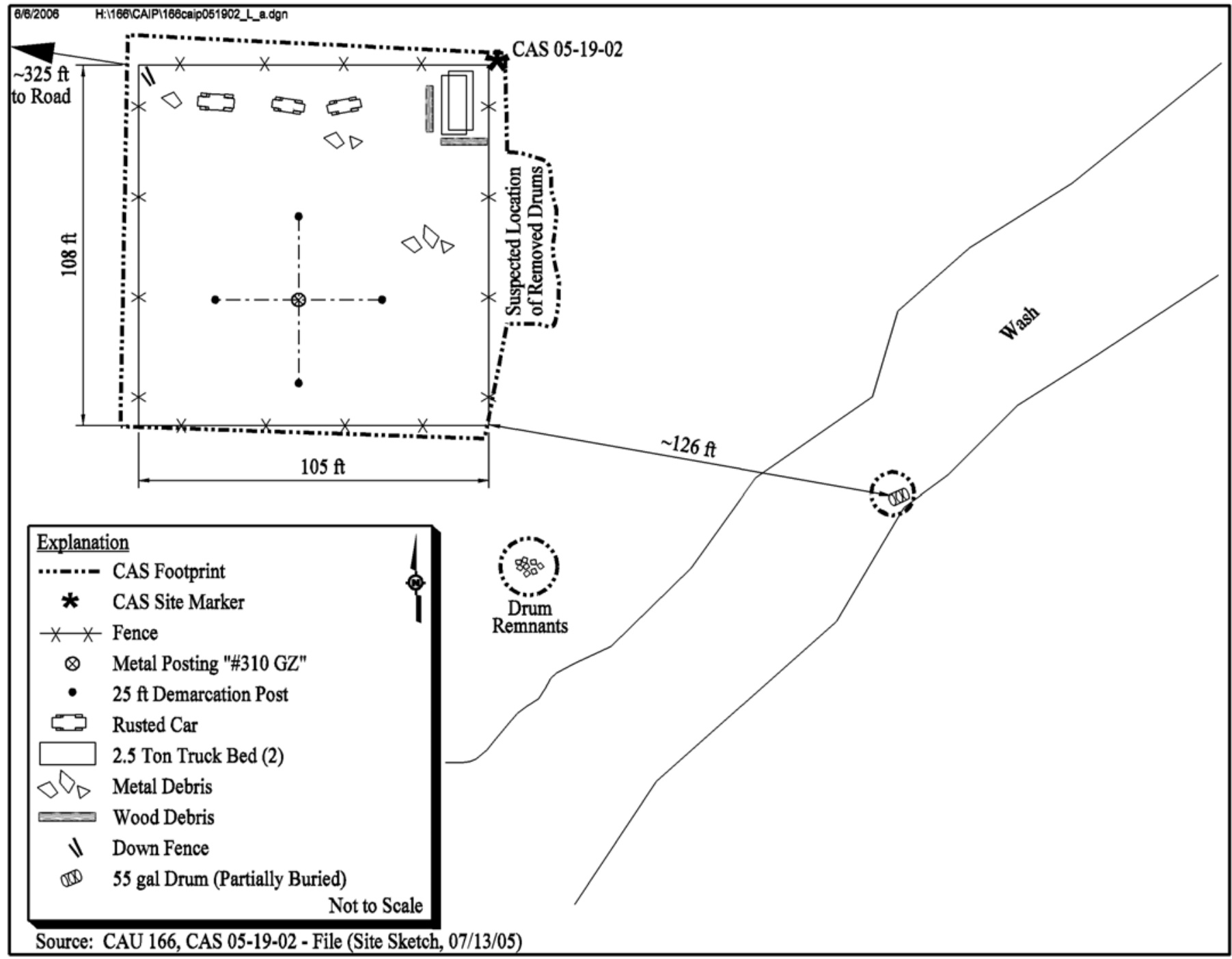

Figure A.2-10

Site Sketch of CAS 05-19-02, Contaminated Soil and Drum 
entire yard is fenced and measures approximately 105 by $108 \mathrm{ft}$. The drums identified in 1990 were located on the east side of the yard, outside of the fence line. Two drums were surveyed that had readings of 600 counts per minute at the surface (Trump, 1991). One drum remains approximately $126 \mathrm{ft}$ east of the yard in the wash. The drum is partially buried with sediment as a result of being located in an active wash. The top and bottom of the drum appears to be intact but there is a crack in one portion of the drum. Sediment is present inside the drum but the remainder of the contents of the drum are unknown. Geophysical surveys indicate that there are no other buried drums or material in the wash. There is nothing to suggest that there is other material buried in the remainder of the footprint. In March 2006, a radiological survey was performed in the remainder of the yard. It was determined that the site poses no risk to individuals from residual radiological contamination for non-intrusive activities (Nicosia, 2006).

\section{A.2.6 Corrective Action Site 18-01-01, Aboveground Storage Tank}

Corrective Action Site 18-01-01 consists of potential release of contaminants to the soil from metal containers and whatever may have been stored in them. The two metal containers are located southeast of the Little Feller II site in Area 18. Figures A.2-11 and A.2-12 shows a site sketch of the CAS.

Physical Setting - CAS 18-01-01 is located in the Alkali Flat Furnace Creek Ranch Subbasin in Area 18. The average annual precipitation for the area, as measured at the rain gauge station at Little Feller II, averaged 7.99 in. for the years 1976 to 2006 (ARL/SORD, 2006). Vegetations consists of sparsely distributed brush. The surrounding undisturbed soil consists of mostly fine soil particles. The thickness of alluvium of the local alluvium layer is unknown. The area is relatively flat but there are rolling hills in the distance. There are no known nearby drainage channels. Well UE-18t is located approximately $1.5 \mathrm{mi}$ northwest of the CAS. The depth to groundwater on September 13, 2005, was measured at $913 \mathrm{ft}$ bgs (USGS/DOE, 2006).

Operational History - It is believed that the area of concern was a neutron flux detector station that measured neutron and gamma absorptions from the Little Feller II atmospheric test that took place in 1962. The material referred to as wax may actually be what documentation calls tissue-equivalent plastic or gel used in the experiment. However, since this is speculation and the FFACO name of the 


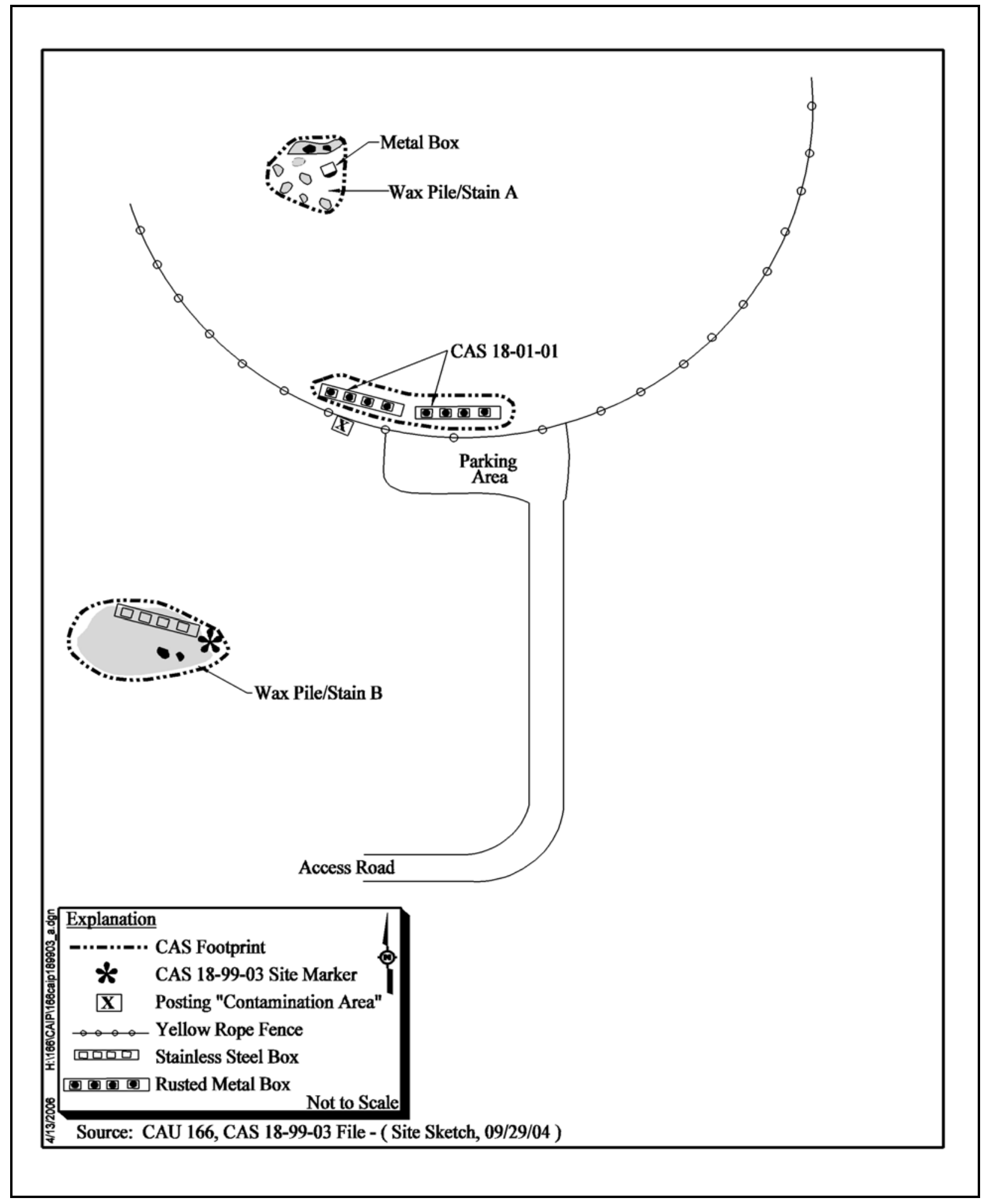

Figure A.2-11

Overview Sketch of CAS 18-01-01, Aboveground Storage Tank and CAS 18-99-03, Wax Piles/Oil Stain 


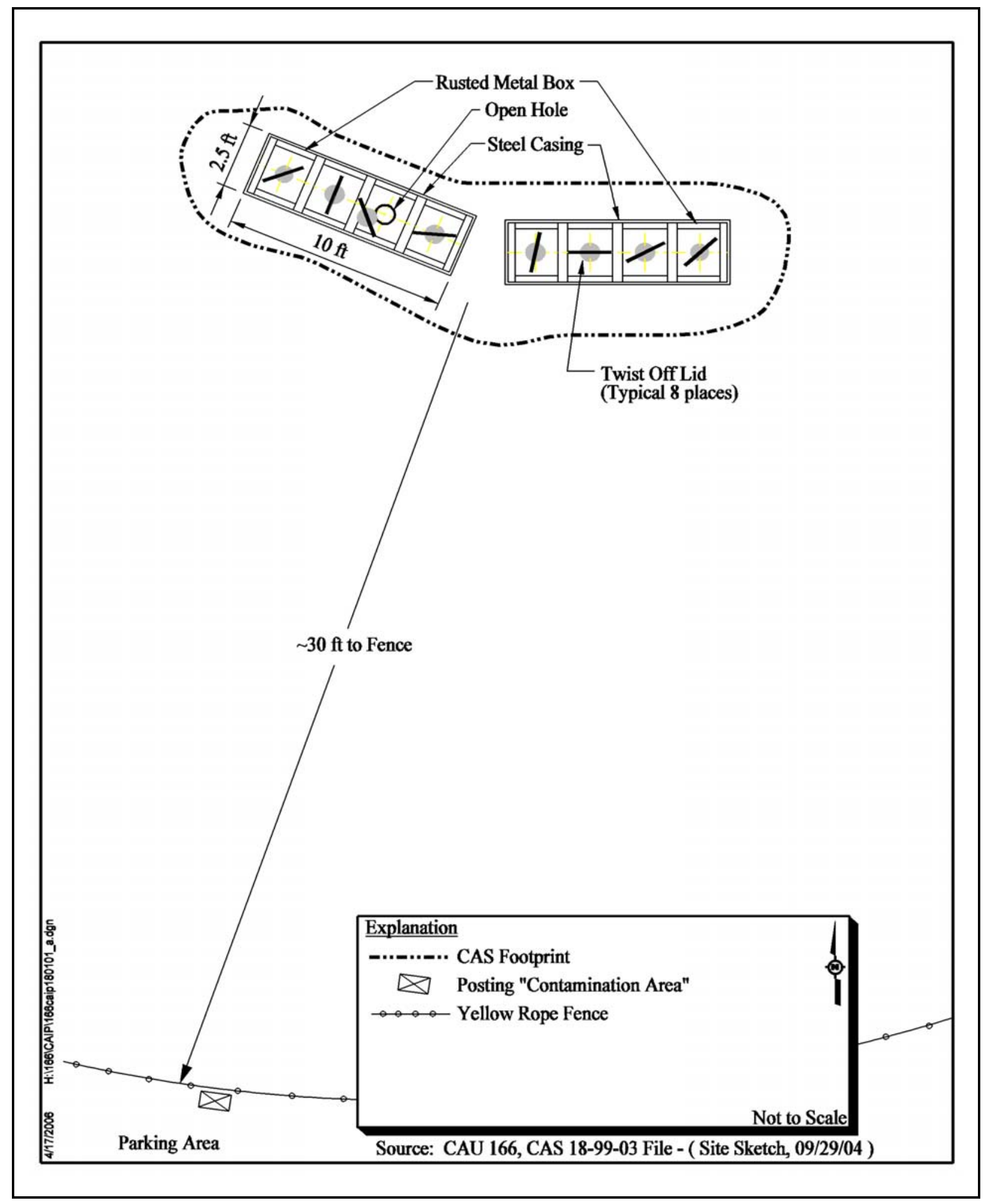

Figure A.2-12

Site Sketch of CAS 18-01-01, Aboveground Storage Tank 
associated CAS 18-99-03 is Wax Piles/Oil Stain, this material will be referred to as wax throughout the rest of this document. It appears that the metal containers were used to hold this material, as there is wax present inside at least one of the metal containers.

Release Information - There are no known releases associated with this CAS.

Previous Investigation Results - Previous investigations of CAS 18-01-01 include site visits and a radiological survey. The site consists of two metal containers located within a posted contamination area. The containers sit on a steel casing that is buried to an unknown depth. There are four circular, twist-off lids on each of the metal containers, with one open lid on the westernmost metal container. There are wax and wood visible within this section of the metal container. Additionally, a hole is visible in the bottom of the box that extends beyond the plane of the box bottom to an unknown depth. It is unknown if this is a pipe that extends beyond the steel casing into the subsurface or if it is merely an extension of the metal container. In March 2006, a radiological survey was performed, and it was determined that the site poses no risk to individuals from residual radiological contamination for non-intrusive activities (Nicosia, 2006). Figures 3-2 and A.2-13 show the metal containers present at this site.

\section{A.2.7 Corrective Action Site 18-99-03, Wax Piles/Oil Stain}

Corrective Action Site 18-99-03 consists of potential release of contaminants to the soil from several wax piles, a metal box, and a metal container. The site is located southeast of the Little Feller II testing area in Area 18. Figures A.2-11, A.2-14, and A.2-15 are site sketches of the CAS.

Physical Setting - CAS 18-99-03 is located in the Alkali Flat Furnace Creek Ranch Subbasin in Area 18. The average annual precipitation for the area, as measured at the rain gauge station at Little Feller II, averaged 7.99 in. for the years 1976 to 2006 (ARL/SORD, 2006). Vegetation consists of sparsely distributed brush. The surrounding undisturbed soil consists of mostly fine soil particles. The thickness of alluvium of the local alluvium layer is unknown. The area is relatively flat but there are rolling hills in the distance. There are no known nearby drainage channels. Well UE-18t is located approximately $1.5 \mathrm{mi}$ northwest of the CAS. The depth to groundwater on September 13, 2005, was measured at $913 \mathrm{ft}$ bgs (USGS/DOE, 2006). 


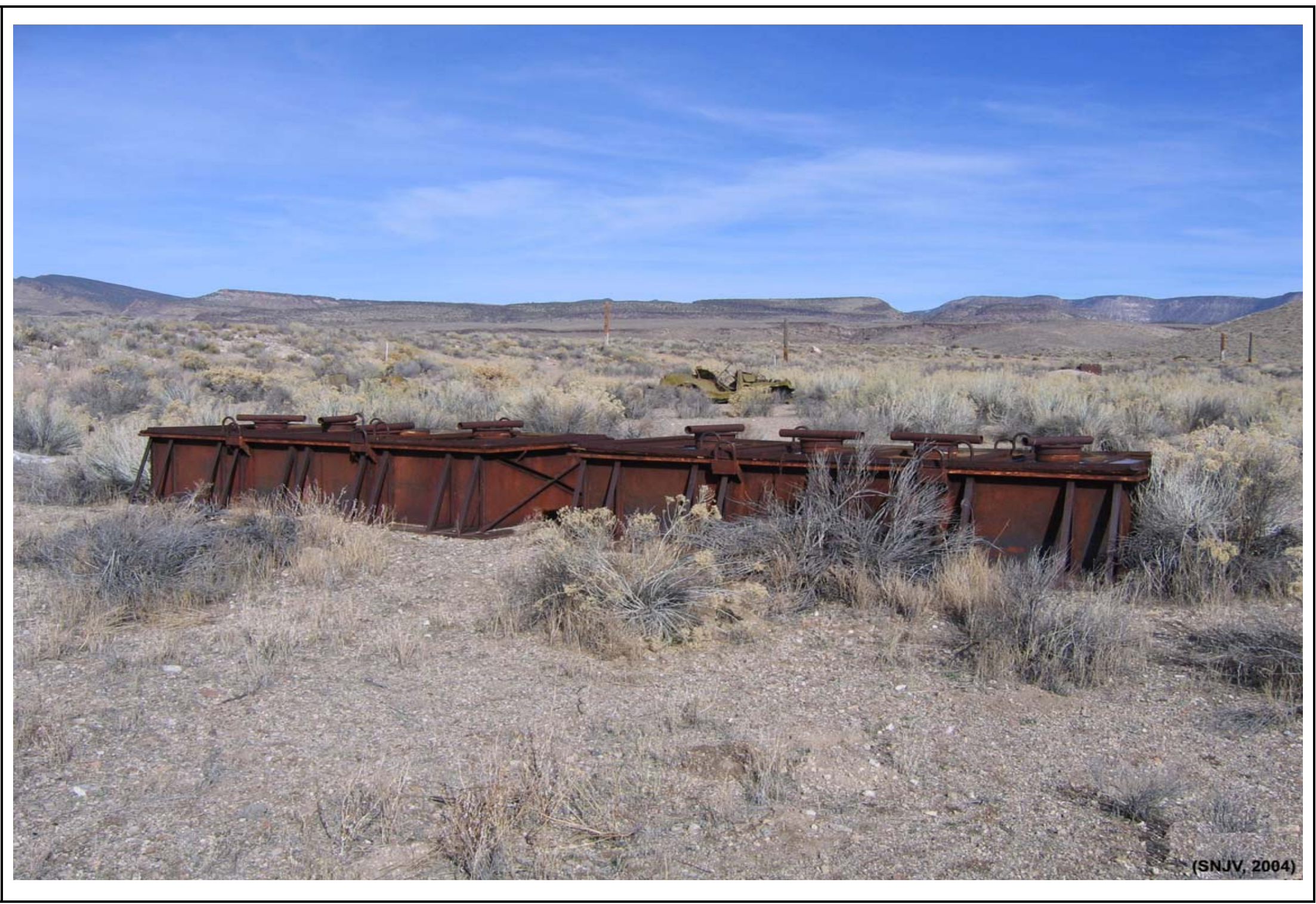

Figure A.2-13

Photograph of CAS 18-01-01, Aboveground Storage Tank

\section{Uncontrolled When Printed}




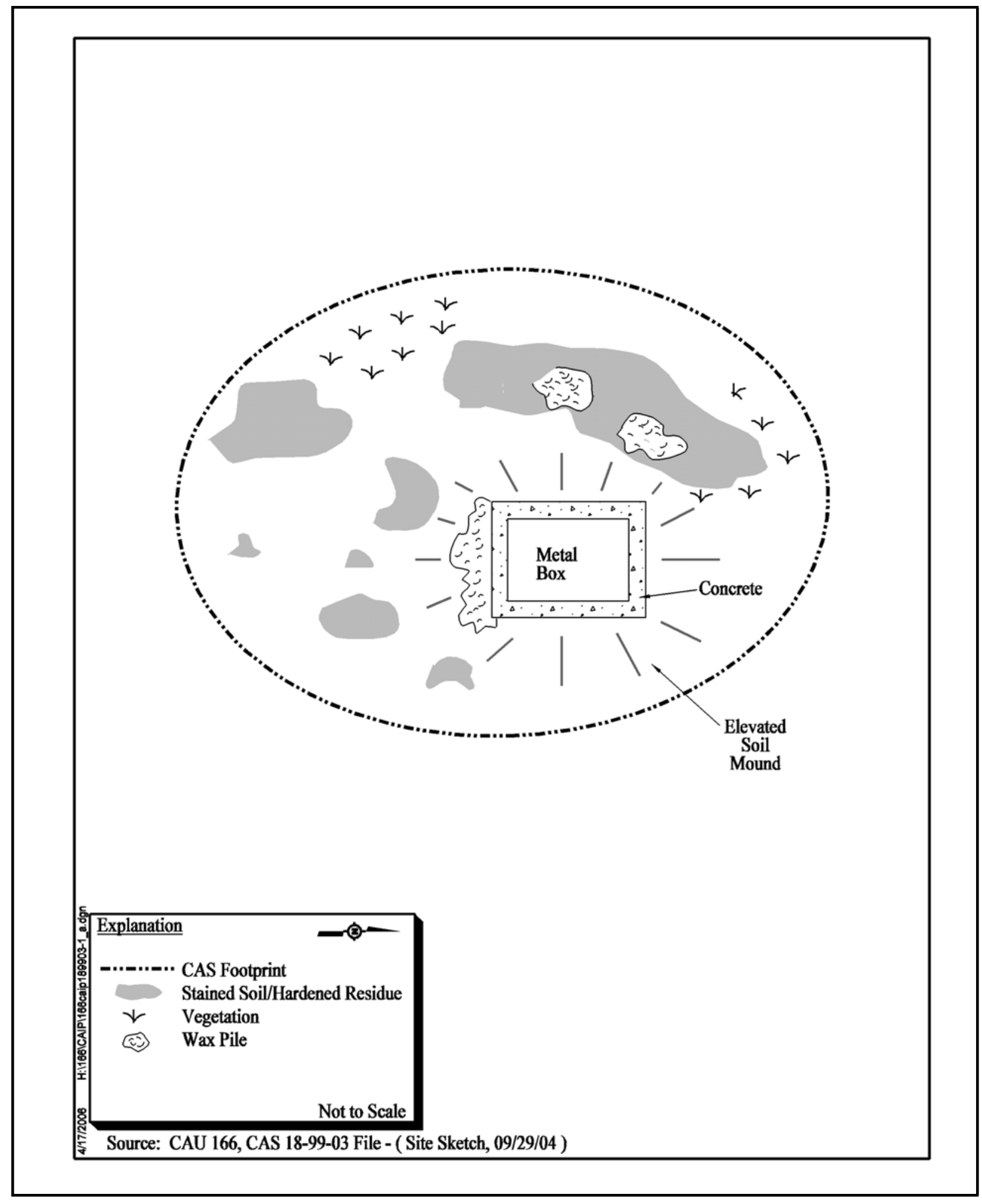

Figure A.2-14

Site Sketch of Site A in CAS 18-99-03, Wax Piles/Oil Stain 


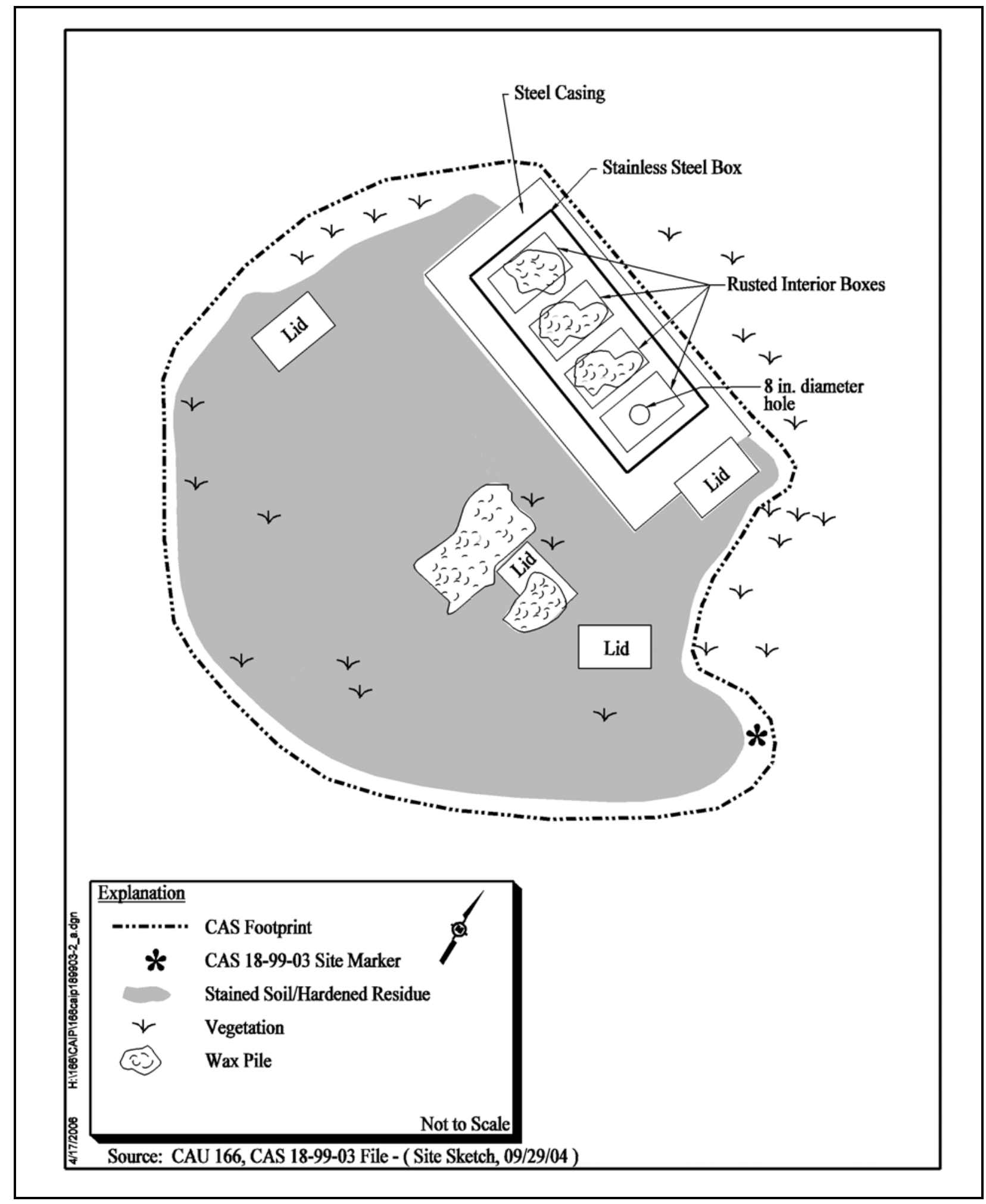

Figure A.2-15

Site Sketch of Site B in CAS 18-99-03, Wax Piles/Oil Stain 
Operational History - It is believed that the area of concern was a neutron flux detector station that measured neutron and gamma absorptions from the Little Feller II atmospheric test that took place in 1962. The material referred to as wax may actually be what documentation calls tissue-equivalent plastic or gel used in the experiment. However, since this is speculation and the FFACO name is Wax Piles/Oil Stain, this material will be referred to as wax throughout the rest of this document. It appears that the metal boxes and containers were used to hold this material as a lot of the wax is still in and on the boxes.

Release Information - There are no known releases associated with this CAS.

Previous Investigation Results - Previous investigations of CAS 18-99-03 include sites visits and a radiological survey. The site consists of Wax Piles/Stains A \& B. Wax Piles/Stains A is located within the posted contamination area, on and around a 3-ft high soil mound. There is a single metal box, approximately 3 by $3 \mathrm{ft}$, on top of the soil mound. There is wax on and adjacent to the south side of this box. There are eight visible soil stains associated with Wax Piles/Stains A that cover an area measuring approximately 10 by $15 \mathrm{ft}$. There is a large pile of wax within the largest stained area, northwest of the box and soil mound. Wax Piles/Stains B is located outside of the fenced contamination area. There is a 10 by $3 \mathrm{ft}$ stainless steel container. This container is sitting on a steel casing that is buried to an unknown depth. Within the container are four smaller, rusted metal boxes; three of which contain wax, while the fourth is empty. The empty box has an 8-in. diameter hole in the bottom of it that appears to extend beyond the plane of the box (Figure A.2-16). It is unknown if this is a pipe that extends beyond the steel casing into the subsurface or if it is merely an extension of the rusted metal box. The boxes have latches to attach lids although the lids have been scattered about the site. Adjacent to the stainless steel box is a wax pile/stain that is irregularly shaped but measures approximately 22 by $15 \mathrm{ft}$ (Figure A.2-17). According to the radiological survey, there are elevated readings within the posted contamination area and radiation services support will be required for future activities (Nicosia, 2006). 


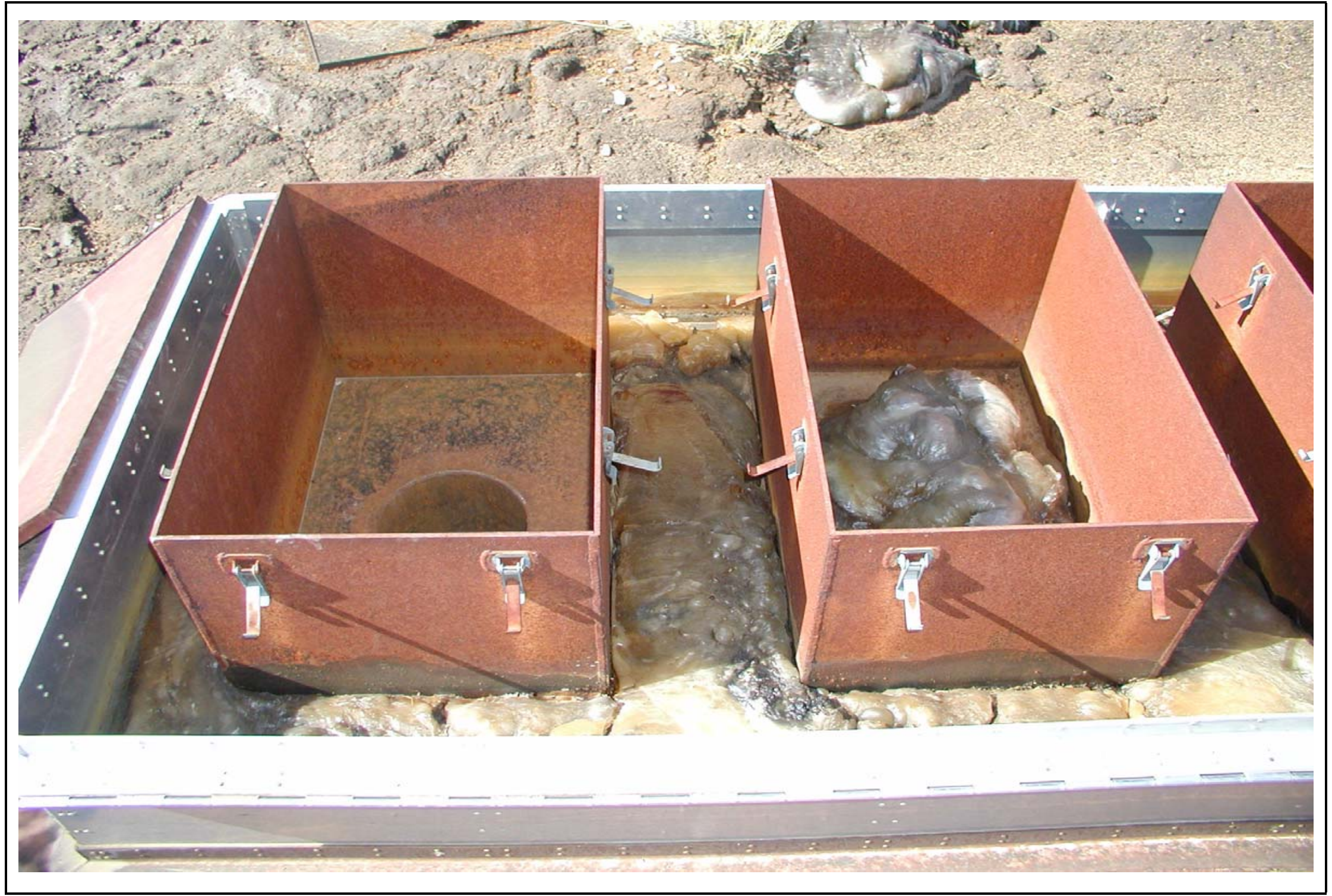

Figure A.2-16

Photograph of the Metal Container at Site B (CAS 18-99-03)

\section{Uncontrolled When Printed}




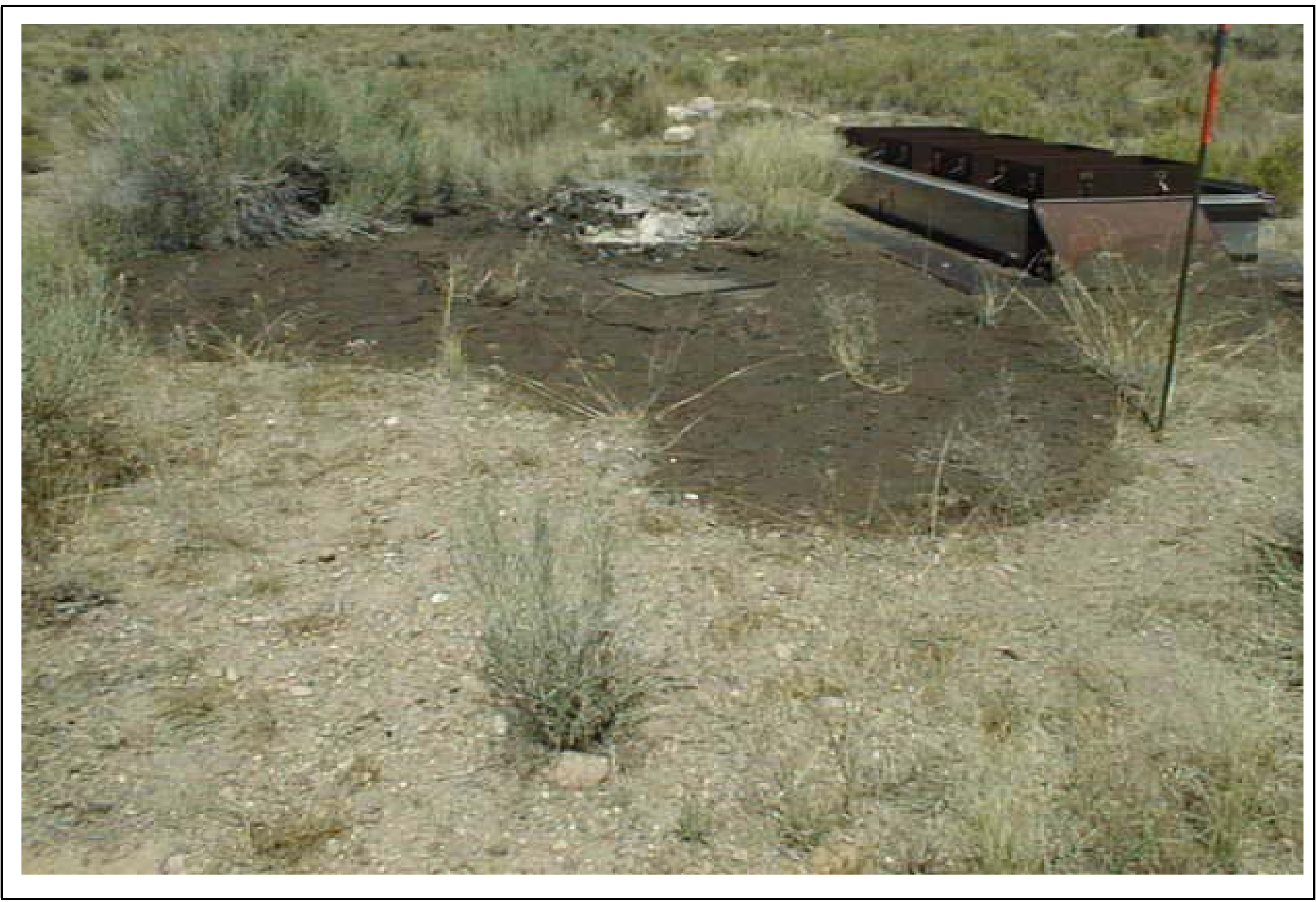

Figure A.2-17

Photograph of the Wax Pile/Hardened Residue at Site B (CAS 18-99-03)

\section{Uncontrolled When Printed}




\section{A.3.0 Step 1 - State the Problem}

The problem statement for CAU 166 is: "Existing information on the nature and extent of potential contamination is insufficient to evaluate and recommend corrective action alternatives for the CASs in CAU 166."

\section{A.3.1 Planning Team Members}

The DQO planning team consists of representatives from NDEP, NNSA/NSO, SNJV, and BN. The primary decision-makers are the NDEP and NNSA/NSO representatives. Table A.3-1 lists representatives from each organization in attendance for the February 28, 2006, DQO meeting.

Table A.3-1

Final DQO Meeting Participants for CAU 166

February 28, 2006

\begin{tabular}{||c|c||}
\hline Affiliation & Department/Project Team Function \\
\hline \hline NDEP & NDEP Representative \\
\hline NNSA/NSO & Environmental Restoration Project Federal Industrial Sites Sub-Project Task Manager \\
\hline BN & Environmental Restoration Task Manager \\
\hline BN & Environmental Restoration Technical Group Supervisor \\
\hline SNJV & Industrial Sites Project Manager \\
\hline SNJV & Industrial Sites Task Manager \\
\hline SNJV & Industrial Sites Technical Coordinator \\
\hline SNJV & Industrial Sites CAU Lead \\
\hline SNJV & Federal Facility Agreement and Consent Order Representative \\
\hline SNJV & Quality Assurance Representative \\
\hline SNJV & Health and Safety Group Representative \\
\hline SNJV & Environmental Compliance and Waste Management Manager \\
\hline SNJV & Environmental Compliance and Waste Management Representative \\
\hline SNJV & Radiation Services Health Physicist \\
\hline
\end{tabular}

$\mathrm{BN}=$ Bechtel Nevada

NDEP = Nevada Division of Environmental Protection

NNSA/NSO = U.S. Department of Energy, National Security Administration Nevada Site Office

SNJV = Stoller-Navarro Joint Venture 


\section{A.3.2 Conceptual Site Model}

The CSM is used to organize and communicate information about site characteristics. It reflects the best interpretation of available information at any point in time. The CSM is a primary vehicle for communicating assumptions about release mechanisms, potential migration pathways, or specific constraints. It provides a good summary of how and where contaminants are expected to move and what impacts such movement may have. It is the basis for assessing how contaminants could reach receptors both in the present and future. The CSM describes the most probable scenario for current conditions at each site and define the assumptions that are the basis for identifying appropriate sampling strategy and data collection methods. Accurate CSMs are important, as they serve as the basis for all subsequent inputs and decisions throughout the DQO process.

The CSM was developed for CAU 166 using information from the physical setting, potential contaminant sources, release information, historical background information, knowledge from similar sites, and physical and chemical properties of the potentially affected media and COPCs.

The CSM represents contamination of the surrounding environment due to migration of contaminants from drilling equipment, tanks, debris, vehicles, drums, and/or wax material that are currently or were formerly present at each of the CASs. Migration of contaminants to areas not presently impacted can occur through either dissolution or suspension of the contaminant in water, followed either by infiltration and percolation into the soil profile, or overland flow from higher to lower elevations. The presence of the wash near one of the CASs could provide an enhanced route for contamination transportation.

The CAU 166, Storage Yards and Contaminated Materials CSM consists of:

- Potential contaminant releases including media subsequently affected.

- Release mechanisms (the conditions associated with the release).

- Potential contaminant source characteristics including contaminants suspected to be present and contaminant-specific properties.

- Site characteristics including physical, topographical, and meteorological information. 
- Migration pathways and transport mechanisms that describe the potential for migration and where the contamination may be transported.

- The locations of points of exposure where individuals or populations may come in contact with a COC associated with a CAS.

- $\quad$ Routes of exposure where contaminants may enter the receptor.

If additional elements are identified during the investigation that are outside the scope of the CSM, the situation will be reviewed and a recommendation will be made as to how to proceed. In such cases, NDEP and NNSA/NSO will be notified and given the opportunity to comment, or concur with, the recommendation.

The applicability of the CSM to each CAS is summarized in Table A.3-2 and discussed below. Table A.3-2 provides information on CSM elements that will be used throughout the remaining steps of the DQO process. Figure A.3-1 represents site conditions applicable to the CSM.

\section{A.3.2.1 Contaminant Release}

All CAU 166 CASs either presently or formerly stored materials associated with testing at the NTS. The native soil interface below and adjacent to any locations that held materials or discharges from these materials is a likely location for soil contamination. The CSM accounts for potential releases resulting from drilling equipment, tanks, debris, vehicles, drums, and/or wax material that are present at the ground surface. Any contaminants migrating from CASs, regardless of physical or chemical characteristics, are expected to exist at interfaces and in the soil adjacent to the storage yards and wax piles in lateral and vertical directions. Concentrations are expected to decrease with horizontal and vertical distance from the source.

\section{A.3.2.2 Potential Contaminants}

The COPCs were identified during the planning process through the review of site history, process knowledge, personal interviews, past investigation efforts (where available), and inferred activities associated with the CASs. Because complete information regarding activities performed at the CAU 166 sites is not available, contaminants detected at similar NTS sites were included in the contaminant lists to reduce uncertainty. The list of COPCs is intended to encompass all of the 
Table A.3-2

Conceptual Site Model Description of Elements for Each CAS in CAU 166

(Page 1 of 2)

\begin{tabular}{|c|c|c|c|c|c|c|c|}
\hline CAS Identifier & $02-42-01$ & $02-42-02$ & 02-99-10 & $03-42-01$ & 05-19-02 & 18-01-01 & $18-99-03$ \\
\hline CAS Description & $\begin{array}{c}\text { Cond. Release } \\
\text { Storage Yd - } \\
\text { North }\end{array}$ & $\begin{array}{c}\text { Cond. Release } \\
\text { Storage Yd - } \\
\text { South }\end{array}$ & $\begin{array}{c}\text { D-38 } \\
\text { Storage } \\
\text { Area }\end{array}$ & $\begin{array}{c}\text { Conditional } \\
\text { Release } \\
\text { Storage Yard }\end{array}$ & $\begin{array}{l}\text { Contaminated } \\
\text { Soil and Drum }\end{array}$ & $\begin{array}{l}\text { Aboveground } \\
\text { Storage Tank }\end{array}$ & $\begin{array}{l}\text { Wax Piles/Oil } \\
\text { Stain }\end{array}$ \\
\hline Site Status & \multicolumn{7}{|c|}{ Sites are inactive and/or abandoned } \\
\hline Future Land Use & \multicolumn{4}{|c|}{ Nuclear and High Explosives Test Zone } & \multicolumn{3}{|c|}{ Reserved (within NTS) Zone } \\
\hline $\begin{array}{l}\text { Sources of Potential } \\
\text { Soil Contamination }\end{array}$ & Drilling equipn & t and debris & $\begin{array}{c}\text { Drums } \\
\text { containing } \\
\text { DU and } \\
\text { drilling } \\
\text { equipment }\end{array}$ & $\begin{array}{c}\text { Drilling } \\
\text { equipment, } \\
\text { tanks, portable } \\
\text { buildings, and } \\
\text { debris }\end{array}$ & $\begin{array}{l}\text { Drums and } \\
\text { vehicles }\end{array}$ & $\begin{array}{l}\text { Wax within two } \\
\text { metal containers }\end{array}$ & $\begin{array}{l}\text { Wax piles on } \\
\text { the ground and } \\
\text { in the metal } \\
\text { containers }\end{array}$ \\
\hline $\begin{array}{l}\text { Location of } \\
\text { Contamination/ } \\
\text { Release Point }\end{array}$ & $\begin{array}{l}\text { Surface soil at or } \\
\text { stored equipr }\end{array}$ & $\begin{array}{l}\text { ar location(s) of } \\
\mathrm{nt} / \mathrm{materials}\end{array}$ & $\begin{array}{l}\text { Surface soil } \\
\text { at or near } \\
\text { location(s) of } \\
\text { stored } \\
\text { equipment/ } \\
\text { materials } \\
\text { and DU } \\
\text { containing } \\
\text { drums }\end{array}$ & $\begin{array}{l}\text { Surface soil at or } \\
\text { near location(s) } \\
\text { of stored } \\
\text { equipment/ } \\
\text { materials }\end{array}$ & $\begin{array}{c}\text { Surface soil at or } \\
\text { near location(s) } \\
\text { of former and } \\
\text { present drums } \\
\text { and } \\
\text { debris/vehicles }\end{array}$ & $\begin{array}{l}\text { Surface soil at or } \\
\text { near location(s) } \\
\text { of the metal } \\
\text { containers }\end{array}$ & $\begin{array}{c}\text { Surface soil at } \\
\text { or near } \\
\text { location(s) of } \\
\text { the wax } \\
\text { piles/stains and } \\
\text { metal } \\
\text { containers }\end{array}$ \\
\hline Amount Released & \multicolumn{7}{|c|}{ Unknown } \\
\hline Affected Media & \multicolumn{5}{|c|}{ Surface and shallow subsurface soil } & \multicolumn{2}{|c|}{$\begin{array}{c}\text { Surface and shallow subsurface } \\
\text { soil }\end{array}$} \\
\hline $\begin{array}{c}\text { Targeted } \\
\text { Contaminants }\end{array}$ & \multicolumn{2}{|c|}{ Unknown } & Uranium-238 & DRO & \multicolumn{3}{|c|}{ Unknown } \\
\hline
\end{tabular}

\section{Uncontrolled When Printed}


Table A.3-2

Conceptual Site Model Description of Elements for Each CAS in CAU 166

(Page 2 of 2)

\begin{tabular}{|c|c|c|c|c|c|c|c|}
\hline CAS Identifier & $02-42-01$ & $02-42-02$ & 02-99-10 & $03-42-01$ & $05-19-02$ & $18-01-01$ & $18-99-03$ \\
\hline CAS Description & $\begin{array}{c}\text { Cond. Release } \\
\text { Storage Yd - } \\
\text { North }\end{array}$ & $\begin{array}{l}\text { Cond. Release } \\
\text { Storage Yd - } \\
\text { South }\end{array}$ & $\begin{array}{c}\text { D-38 } \\
\text { Storage } \\
\text { Area }\end{array}$ & $\begin{array}{l}\text { Conditional } \\
\text { Release } \\
\text { Storage Yard }\end{array}$ & $\begin{array}{l}\text { Contaminated } \\
\text { Soil and Drum }\end{array}$ & $\begin{array}{l}\text { Aboveground } \\
\text { Storage Tank }\end{array}$ & $\begin{array}{c}\text { Wax Piles/Oil } \\
\text { Stain }\end{array}$ \\
\hline $\begin{array}{c}\text { Transport } \\
\text { Mechanisms }\end{array}$ & \multicolumn{7}{|c|}{$\begin{array}{l}\text { Surface water runoff of dissolved or suspended contaminants is the most likely potential transport mechanism for waste materials placed } \\
\text { on soils within or outside of the footprints of the CASs. The potential for overland migration of contaminants increases with slope gradient } \\
\text { and precipitation amount. Infiltration and percolation of precipitation through subsurface media could serve as a major driving force for } \\
\text { migration of contaminants. However, due to the arid environment of the Nevada Test Site, percolation of precipitation is very small and } \\
\text { migration of contaminants has been shown to be limited. Evaporation potentials significantly exceed available soil moisture from } \\
\text { precipitation (i.e., } 3 \text { to } 10 \text { inches) (USGS, 1995a). }\end{array}$} \\
\hline Migration Pathways & \multicolumn{7}{|c|}{ Lateral transport expected to dominate over vertical transport } \\
\hline $\begin{array}{c}\text { Lateral and Vertical } \\
\text { Extent of } \\
\text { Contamination }\end{array}$ & \multicolumn{7}{|c|}{$\begin{array}{l}\text { Unknown. Contamination, if present, is expected to be contiguous to the release points. Concentrations are expected to decrease with } \\
\text { distance and depth from the source. Groundwater contamination is not expected. Depth to groundwater near the CASs in Areas } 2 \text { and } 3 \\
\text { ranges from approximately } 1,600 \text { to } 2,050 \mathrm{ft} \text { bgs (USGS, 1995b). Depth to groundwater near the Area } 5 \text { CAS is approximately } 710 \mathrm{ft} \text { bgs } \\
\text { while the depth to groundwater near the Area } 18 \text { CASs is approximately } 910 \mathrm{ft} \text { bgs (USGS/DOE, 2006). Surface migration may occur as } \\
\text { a result of runoff. }\end{array}$} \\
\hline Exposure Scenario & \multicolumn{7}{|c|}{$\begin{array}{l}\text { The CAU } 166 \text { CASs meet the criteria of Occasional Use Areas. The potential for contamination exposure is limited to industrial and } \\
\text { construction workers, and military personnel conducting training. }\end{array}$} \\
\hline
\end{tabular}

CAS $=$ Corrective Action Site

$\mathrm{DRO}=$ Diesel-range organics

$\mathrm{DU}=$ Depleted uranium

$\mathrm{ft}$ bgs $=$ Foot below ground surface 


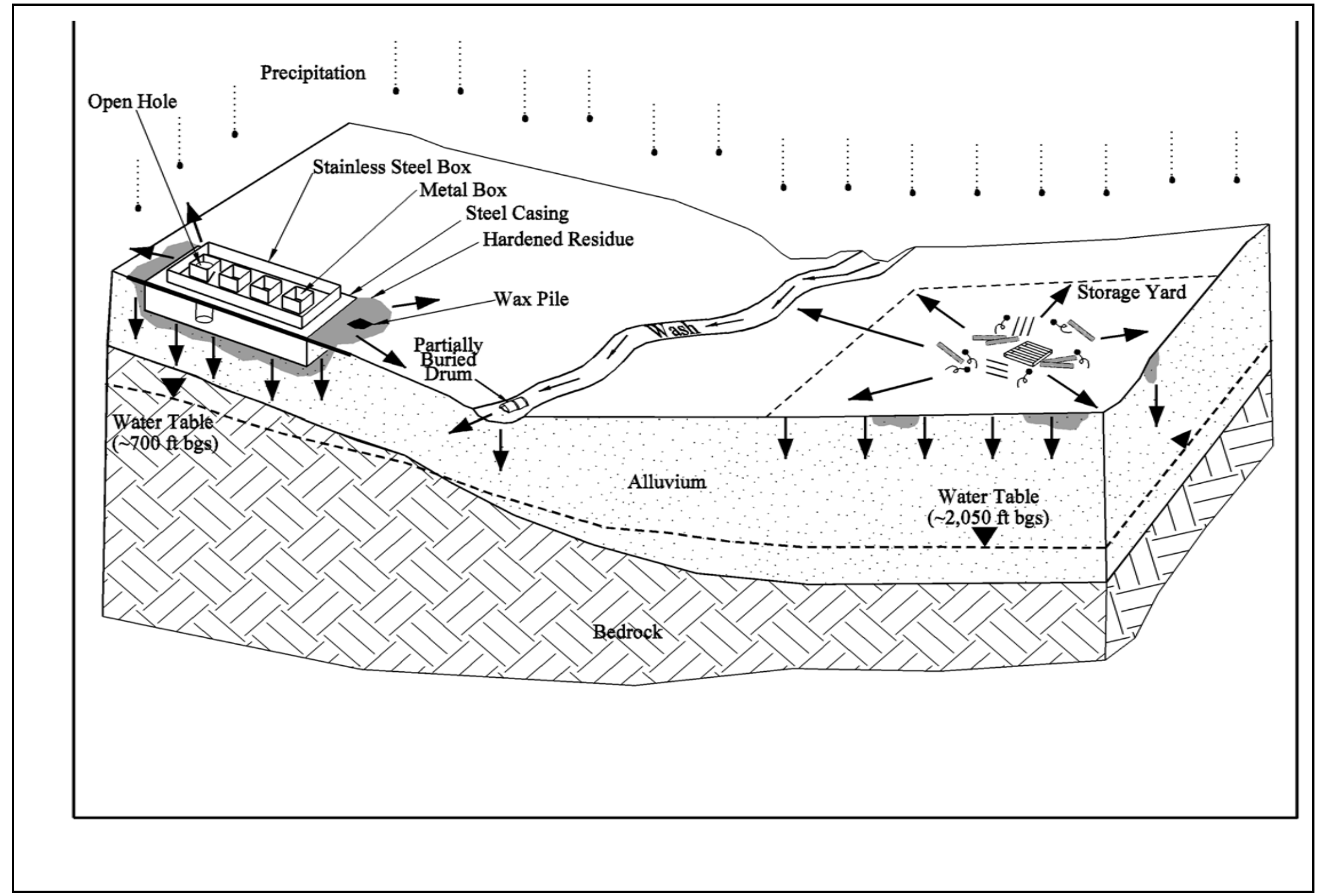

Figure A.3-1

Conceptual Site Model for CAU 166

\section{Uncontrolled When Printed}


contaminants that could potentially be present at each CAS. The COPCs applicable to Decision I environmental samples from each of the CASs of CAU 166 are defined as the constituents reported from the analytical methods stipulated in Table 3-1.

\section{A.3.2.3 Contaminant Characteristics}

Contaminant characteristics include, but are not limited to: solubility, density, and adsorption potential. In general, contaminants with low solubility, high affinity for media, and high density can be expected to be found relatively close to release points. Contaminants with small particle size, high solubility, low density, and/or low affinity for media are found further from release points or in low areas where evaporation of ponding will concentrate dissolved contaminants.

\section{A.3.2.4 Site Characteristics}

Site characteristics are defined by the interaction of physical, topographical, and meteorological attributes and properties. Physical properties include permeability, porosity, hydraulic conductivity, degree of saturation, sorting, chemical composition, and organic content. Topographical and meteorological properties and attributes include slope stability, precipitation frequency and amounts, precipitation runoff pathways, drainage channels and ephemeral streams, and evapotranspiration potential.

Corrective Action Sites 02-42-01, 02-42-02, and 02-99-10 are located adjacent to each other near the Area 2 Camp in NTS Area 2. The area around the site is generally flat, with washes in the area draining southeast towards Yucca Flat. There are several craters and test holes in the vicinity of the CASs. The nearest crater and test hole is approximately 2,500 ft southeast of CAS 02-99-10, 3,000 ft southeast of CAS 02-42-01, and 3,300 ft east of CAS 02-42-02. Transport of contaminants at this site would occur through erosion/mass transport in surface waters (see Figure 3-1) into nearby washes leaving the area, test holes, or craters (Figure A.3-1).

Corrective Action Site 03-42-01 is located in the Area 3 Camp in NTS Area 3. The area around the site is relatively flat, with washes in the area draining southeast towards Yucca Flat (closest wash is in a different drainage basin than the CAS). There are several craters and test holes in the vicinity of the site. The nearest test hole is approximately $1,470 \mathrm{ft}$ east of the CAS while the nearest test hole that 
cratered is 2,260 ft southwest of the site. Transport of contaminants at this site would occur through erosion/mass transport in surface waters (see Figure 3-1) into nearby washes leaving the area, test holes, or craters (Figure A.3-1).

Corrective Action Site 05-19-02 is located 1.4 miles east of Mercury Highway. The area around the site is generally flat. A wash runs through the CAS footprint that drains west toward Frenchman Lake drainage basin. There are no test holes or craters in the vicinity of the CAS. Transport of contaminants at this site would occur through erosion/mass transport in surface waters (see Figure 3-1) into the adjacent wash (Figure A.3-1).

Corrective Action Sites 18-01-01 and 18-99-03 are located southwest of the Little Feller II test area in NTS Area 18. The area around the site is slightly hilly with washes in the area draining north within the Forty Mile Wash drainage basin. There are no test holes or craters in the vicinity of the CAS. Transport of contaminants at this site would occur through erosion/mass transport in surface waters (see Figure 3-1) into nearby washes leaving the area (Figure A.3-1).

\section{A.3.2.5 Migration Pathways and Transport Mechanisms}

Movement of liquid or solid contaminants away from the point of release at the CAU 166 CASs are mainly related to the movement of water by percolation into subsurface media or by overland migration with flowing water. Infiltration and percolation of precipitation serves as a driving force for downward migration of contaminants. However, due to high potential evapotranspiration (annual potential evapotranspiration at the Area 3 Radiological Waste Management Site has been estimated at 62.6 in. [Shott et al., 1997]) and limited precipitation for this region (6 to 8 in. per year [Winograd and Thordarson, 1975]), percolation of infiltrated precipitation at the NTS does not provide a significant mechanism for vertical migration of contaminants to groundwater (DOE/NV, 1992).

Airborne migration of contaminants is considered a minor transport mechanism for CAU 166. If migration of contaminants at the seven CASs in CAU 166 were to have occurred, the dominant transport mechanism would be erosion/mass transport by surface runoff of precipitation (Figure A.3-1). Flowing water has the potential to carry dissolved and suspended contaminants. The migration pathway through which the contamination from the CASs in CAU 166 might migrate is 
surface water (see Figure 3-1). Washes, such as those that lie on or near the footprints of CASs 05-19-02, can carry runoff water and possible contaminants away from the original site of release. Other land features such as craters and test holes could receive runoff water and possible contaminants (Figure A.3-1). This transport mechanism is depicted in the CSM as the means for contamination to move from the point of release to other areas, impacting sediments and surface soils that become potential exposure points, including areas outside the CAS boundaries.

\section{A.3.2.6 Exposure Scenarios}

Human receptors may be exposed to COPCs through oral ingestion, inhalation, dermal contact (absorption) of soil or debris due to inadvertent disturbance of these materials or exposure to radioactive materials. The land use and exposure scenarios for the CAU 166 CASs are listed in Table A.3-3. These are based on NTS current and future land use. All seven CASs in CAU 166 are at remote locations without any site improvements and where no regular work is performed. There is still the possibility, however, that site workers could occupy these locations on an occasional and temporary basis such as a military exercise. Therefore, these sites are classified as occasional work areas.

Table A.3-3

Future Land-Use Zones and Exposure Scenarios

\begin{tabular}{|c|c|c|}
\hline CAS & Record of Decision Land-Use Zone & Exposure Scenario \\
\hline $\begin{array}{l}02-42-01,02-42-02 \\
02-99-10,03-42-01\end{array}$ & $\begin{array}{l}\text { Nuclear and High Explosives Test } \\
\text { This area is designated within the Nuclear } \\
\text { Test Zone for additional underground } \\
\text { nuclear weapons tests and outdoor } \\
\text { high-explosive tests. This zone includes } \\
\text { compatible defense and nondefense } \\
\text { research, development, and testing } \\
\text { activities. }\end{array}$ & \multirow{2}{*}{$\begin{array}{l}\text { Occasional Use Area } \\
\text { Remote area with no active improvements } \\
\text { and the future land use designation is for } \\
\text { outdoor tests and/or military training } \\
\text { exercises. }\end{array}$} \\
\hline $\begin{array}{c}\text { 05-19-02, 18-01-01, } \\
18-99-03\end{array}$ & $\begin{array}{l}\text { Reserved (within NTS area) } \\
\text { This area includes land and facilities that } \\
\text { provide widespread flexible support for } \\
\text { diverse short-term testing and } \\
\text { experimentation. The reserved zone is } \\
\text { also used for short duration exercises and } \\
\text { training such as nuclear emergency } \\
\text { response and Federal Radiological } \\
\text { Monitoring and Assessment Canter } \\
\text { training and U.S. Department of Defense } \\
\text { land-navigation exercises and training. }\end{array}$ & \\
\hline
\end{tabular}


The future land-use scenarios for all seven CASs in CAU 166 support these exposure scenarios (DOE/NV, 1998). The nature of these future land-use zones precludes the presence of the site workers except on a temporary basis during the various activities. 


\section{A.4.0 Step 2 - Identify the Decisions}

Step 2 of the DQO process identifies the decision statements and defines appropriate alternative actions that may be taken, depending on the answer to the decision statements.

\section{A.4.1 Decision Statements}

The Decision I statement is: "Is any COC present in environmental media within the CAS?” For judgmental sampling design, any analytical result for a COPC above the FAL will result in that COPC being designated as a COC. For probability (random) sampling design, any COPC that has a 95 percent UCL of the average concentration above the FAL will result in that COPC being designated as a COC. A COC may also be defined as a contaminant that, in combination with other like contaminants, is determined to jointly pose an unacceptable risk based on a multiple constituent analysis (NNSA/NSO, 2006). If a COC is detected, then Decision II must be resolved.

The Decision II statement is: "If a COC is present, is sufficient information available to evaluate potential corrective action alternatives?” Sufficient information is defined to include:

- Identification of the volume of media containing any COC bounded by analytical sample results in lateral and vertical directions.

- Characterization of IDW for disposal.

- Determination of potential remediation waste types.

- Evaluation of the feasibility of potential corrective actions.

A corrective action will be determined for any site containing a COC. The evaluation of the need for corrective action will include the potential for wastes that are present at a site to cause the future contamination of site environmental media if the wastes were to be released. To evaluate the potential for a release from site wastes to result in the introduction of a COC to the surrounding environmental media, the following conservative assumptions were made:

- All containment would fail at some point and the contents would be released to the surrounding media. 
- Resulting concentration of contaminants in the surrounding media would be equal to the concentration of contaminants in any non-liquid waste.

- Any liquid waste contaminant concentrations exceeding the RCRA toxicity characteristic concentration can result in COC introduction to the surrounding media.

Non-liquid wastes containing a contaminant exceeding an equivalent FAL concentration would be considered to be potential source material and would require a corrective action. Liquid wastes with contaminant concentrations exceeding an equivalent toxicity characteristic action level would be considered to be potential source material and would require a corrective action.

If sufficient information is not available to evaluate potential corrective action alternatives, then site conditions will be re-evaluated and additional samples will be collected (as long as the scope of the investigation is not exceeded and any CSM assumption has not been shown to be incorrect).

\section{A.4.2 Alternative Actions to the Decisions}

In this section, the actions that may be taken to solve the problem are identified depending on the possible outcomes of the investigation.

\section{A.4.2.1 Alternative Actions to Decision I}

If no COC associated with a release from the CAS is detected, then further assessment of the CAS is not required. If a COC associated with a release from the CAS is detected, then the extent of COC contamination will be determined and additional information required to evaluate potential corrective action alternatives will be collected.

\section{A.4.2.2 Alternative Actions to Decision II}

If sufficient information is available to evaluate potential corrective action alternatives, then further assessment of the CAS is not required. If sufficient information is not available to evaluate potential corrective action alternatives, then additional samples will be collected. 


\section{A.5.0 Step 3 - Identify the Inputs to the Decision}

This step identifies the information needed, determines information sources, and identifies sampling and analysis methods that will allow reliable comparisons with FALs.

\section{A.5.1 Information Needs}

To resolve Decision I (determine whether a COC is present at a given CAS), samples shall be collected and analyzed following these criteria:

- Samples must be (a) collected in areas most likely to contain a COC (judgmental sampling) or (b) properly represent contamination at the CAS (probabilistic sampling)

- The analytical suite selected must be sufficient to identify any COCs present in the samples.

To resolve Decision II (determine whether sufficient information is available to evaluate potential corrective action alternatives at each CAS), samples need to be collected and analyzed to meet the following criteria:

- Samples must be collected in areas contiguous to the contamination but where contaminant concentrations are below FALs.

- Samples of the waste or environmental media must provide sufficient information to characterize the IDW for disposal.

- Samples of the waste or environmental media must provide sufficient information to determine potential remediation waste types.

- Appropriate samples must be submitted to evaluate the feasibility of potential corrective actions.

- The analytical suites selected must be sufficient to detect contaminants at concentrations equal to or less than their corresponding FALs.

\section{A.5.2 Sources of Information}

Information to satisfy Decision I and Decision II will be generated by collecting environmental samples using grab sampling, hand augering, direct push, backhoe excavation, or other appropriate 
sampling methods. These samples will be submitted to analytical laboratories meeting the quality criteria stipulated in the Industrial Sites QAPP (NNSA/NV, 2002a). Only validated data from analytical laboratories will be used to make DQO decisions. Sample collection and handling activities will follow standard procedures.

\section{A.5.2.1 Sample Locations}

Design of the sampling approaches for the CAU 166 CASs must ensure that the data collected are sufficient for selection of the corrective action alternatives (EPA, 2002). To meet this objective, the samples collected from each site should either be from locations that most likely contain a COC, if present (judgmental), properly represent any contamination at the CAS. These sample locations, therefore, can be selected by means of (a) biasing factors used in judgmental sampling (e.g., a stain, likely containing a spilled substance) or (b) a probabilistic sampling design. Because the information available to develop judgmental sampling varies in scope among the CAU 166 CASs, both judgmental and probabilistic sampling approaches are used for the CAI. A judgmental sampling design has been developed for CASs 18-01-01 and 18-99-03, due to the presence and significance of biasing factors. A probabilistic sampling design has been developed for CASs 02-42-01, 02-42-02, and 02-99-10, due to the lack of significant biasing factors. A combination of biasing factors and probabilistic sampling will be applied at CASs 03-42-01 and 05-19-02

The implementation of judgmental and probabilistic approach for sample location selection for CAU 166 are discussed in the following sections. Appendix C provides the methodology and computational approach for probabilistic sampling, and lists the sample size and locations as calculated by the VSP software program, including the values established as input for selecting sample size (PNNL, 2005).

\section{A.5.2.1.1 Judgmental Approach for Sampling Location Selection}

Decision I sample locations at CASs 18-01-01, 18-99-03, and portions of CASs 03-42-01 and 05-19-02, will be determined based upon the likelihood of the soil containing a COC, if present at the CAS. These locations will be selected based on field-screening techniques, biasing factors, the CSM, 
and existing information. Analytical suites for Decision I samples will include all COPCs identified in Table A.3-3.

Field-screening techniques may be used to select appropriate sampling locations by providing semiquantitative data that can be used to comparatively select samples to be submitted for laboratory analyses from several screening locations. Field screening may also be used for health and safety monitoring and to assist in making certain health and safety decisions. The following field-screening methods may be used to select analytical samples at CAU 166:

- Walkover surface area radiological surveys - A radiological survey instrument will be used over approximately 100 percent of the CAS boundaries, as permitted by terrain and field conditions, to detect hot spots of radiological contamination.

- Alpha and beta/gamma radiation - A radiological survey instrument will be used.

- Gamma emitting radionuclides - A radiological dose rate measurement instrument will be used.

Biasing factors may also be used to select samples to be submitted for laboratory analyses based on existing site information and site conditions discovered during the investigation. The following factors will also be considered in selecting locations for analytical samples at CAU 166:

- $\quad$ Documented process knowledge on source and location of release (e.g., volume of release).

- Stains: Any spot or area on the soil surface that may indicate the presence of a potentially hazardous liquid. Typically, stains indicate an organic liquid such as an oil has reached the soil, and may have spread out vertically and horizontally.

- Elevated radiation: Any location identified during radiological surveys that had alpha/beta/gamma levels significantly higher than surrounding background soil.

- Geophysical anomalies: Any location identified during geophysical surveys that had results indicating surface or subsurface materials existed, and were not consistent with the natural surroundings (e.g., buried concrete or metal, surface metallic objects).

- Drums, containers, equipment or debris: Materials of interest that may have been used at, or added to, a location, and that may have contained or come in contact with hazardous or radioactive substances at some point during their use. 
- Lithology: Locations where variations in lithology (soil or rock) indicate that different conditions or materials exist.

- Preselected areas based on process knowledge of the site: Locations for which evidence such as historical photographs, experience from previous investigations, or interviewee input, exists that a release of hazardous or radioactive substances may have occurred.

- Preselected areas based on process knowledge of the contaminant(s): Locations that may reasonably have received contamination, selected on the basis of the chemical and/or physical properties of the contaminant(s) in that environmental setting.

- Previous sample results: Locations that may reasonably have been contaminated based upon the results of previous field investigations.

- Experience and data from investigations of similar sites.

- Visual indicators such as discoloration, textural discontinuities, disturbance of native soils, or other indication of potential contamination.

- $\quad$ Presence of debris, waste, or equipment.

- Odor.

- Physical and chemical characteristics of contaminants.

- Other biasing factors: Factors not previously defined for the CAI, but become evident once the investigation of the site is under way; previous sample or screening results.

Decision II sample step-out locations will be selected based on the CSM, biasing factors, and existing data. Analytical suites will include those parameters that exceeded FALs (i.e., COCs) in prior samples. Biasing factors to support Decision II sample locations include Decision I biasing factors plus available analytical results.

\section{A.5.2.1.2 Probabilistic Approach for Sample Location Selection}

The number and location of Decision I samples at CASs 02-42-01, 02-42-02, 02-99-10, and portions of CASs 03-42-01 and 05-19-02 were selected during the DQO meeting. Several parameters must be established to determine the number of samples required to be collected for each significant COPC. A significant COPC is defined as any constituent that is detected in any sample at a concentration greater than the PAL. The input parameters that will be used to determine the number of samples 
required to make DQO decisions are summarized in Table A.5-1 and are presented in Appendix C. Individual CAS probabilistic sampling and analysis designs are discussed in Section A.9.1 (CASs 02-42-01, 02-42-02, and 02-99-10), Section A.9.2 (CAS 03-42-01), and Section A.9.3 (CAS 05-19-02).

Table A.5-1

Parameter Values for Calculating Sample Size

\begin{tabular}{|c|l|}
\hline Parameter & \multicolumn{1}{|c|}{ Description } \\
\hline \hline Sampling Goal & Compare average to fixed threshold \\
\hline Distribution & $\begin{array}{l}\text { Data not assumed to be normally distributed } \\
\text { Ordinary sampling of symmetric distribution }\end{array}$ \\
\hline Hypothesis & Assume site is dirty \\
\hline False Rejection Rate & $5 \%$ \\
\hline False Acceptance Rate & $20 \%$ \\
\hline Standard Deviation & Actual significant COPC standard deviation \\
\hline Average & Actual significant COPC average concentration \\
\hline Gray Region Width & Average concentration \\
\hline
\end{tabular}

The sufficiency of the number of samples collected will be evaluated following the CAI based on a recalculation of the sample size based on the actual data. For COC analytical results reported as not detected, one-half of the detection limit values will be used to calculate statistical parameters (EPA, 1989). All calculations for the determination of sample size sufficiency will be provided in the investigation report.

\section{A.5.2.2 Analytical Methods}

Analytical methods are available to provide the data needed to resolve the decision statements. The analytical methods and laboratory requirements (e.g., detection limits, precision, and accuracy) are provided in Tables 3-4 and 3-5 along with specific analyses required for the disposal of IDW. 


\section{A.6.0 Step 4 - Define the Boundaries of the Study}

The purpose of this step is to define the population of interest, define the spatial boundaries, determine practical constraints on data collection, and define the scale of decision making.

\section{A.6.1 Populations of Interest}

The population of interest to resolve Decision I ("Is any COC present in environmental media within the CAS?”) is (a) any location within the site that is contaminated with any contaminant above a FAL (judgmental sampling) or (b) locations representative of total site contamination (probabilistic sampling). The populations of interest to resolve Decision II ("If a COC is present, is sufficient information available to evaluate potential corrective action alternatives?”) are:

- Each one of a set of locations bounding contamination in lateral and vertical directions.

- Investigation-derived waste or environmental media that must be characterized for disposal.

- Potential remediation waste.

- Environmental media where natural attenuation or biodegradation or construction/evaluation of barriers is considered.

\section{A.6.2 Spatial Boundaries}

Spatial boundaries are the maximum lateral and vertical extent of expected contamination at each CAS, as shown in Table A.6-1. Contamination found beyond these boundaries may indicate a flaw in the CSM and may require re-evaluation of the CSM before the investigation could continue. Each CAS is considered geographically independent and intrusive activities are not intended to extend into the boundaries of neighboring CASs.

\section{A.6.3 Practical Constraints}

Investigation of these CASs may be impacted by physical constraints and activities at the NTS. Underground utilities, shallow bedrock, equipment in the storage yards, overhead power lines, and bordering CASs can limit intrusive sampling locations. Other practical constraints include soft 
Table A.6-1

Spatial Boundaries of CAU 166 CASs

\begin{tabular}{|c|l||}
\hline Corrective Action Site & \multicolumn{1}{|c|}{ Spatial Boundaries } \\
\hline \hline $02-42-01,02-42-02,02-99-10,03-42-01$ & $\begin{array}{l}\text { The footprint of the storage yard plus a 20-foot (ft) lateral and } \\
15-\mathrm{ft} \text { vertical buffer. }\end{array}$ \\
\hline $05-19-02$ & $\begin{array}{l}\text { The footprint of the storage yard plus a 20-ft lateral and 15-ft } \\
\text { vertical buffer. The footprint of the drum plus } 50 \mathrm{ft} \text { laterally down } \\
\text { stream of the wash and 15 } \mathrm{ft} \text { vertically. }\end{array}$ \\
\hline $18-01-01,18-99-03$ & $\begin{array}{l}\text { The area around the metal boxes and stained soil containing wax } \\
\text { plus a 20-ft lateral and 15-ft vertical buffer. }\end{array}$ \\
\hline
\end{tabular}

sediment terrain and access restrictions. Access restrictions include scheduling conflicts on the NTS with other entities, areas posted as contamination areas requiring appropriate work controls, physical barriers (e.g., fences), and areas requiring authorized access. Underground utilities surveys will be conducted at each CAS prior to the start of investigation activities to determine whether utilities exist, and, if so, determine the limit of spatial boundaries for intrusive activities. Sample locations at CASs 18-01-01 and 18-99-03 within the contamination area may need to be revised due to as-low-as-reasonably-achievable goals.

\section{A.6.4 Define the Scale of Decision Making}

The scale of decision making for CASs 02-42-01, 02-42-02, 02-99-10, 18-01-01, and 18-99-03 is defined as the CAS. At CAS 03-42-01, separate decisions may be made for the posted RMA and the unposted (unfenced) portion of the storage yard. A CAS 05-19-02, separate decisions may be made for the storage yard, the drum location, drum storage area, and drum remnants location. Any COC detected within any potential decision-making area will cause the determination that the area is contaminated and needs further evaluation. The scale of decision making for Decision II is defined as the contiguous area contaminated with any COC. Resolution and Decision II requires this contiguous area to be bounded laterally and vertically. 


\section{A.7.0 Step 5 - Develop a Decision Rule}

This step develops a decision rule (“If..., then...”) statement that defines the conditions under which possible alternative actions will be chosen. In this step, we specify the statistical parameters that characterizes the population of interest, specify the FALs, confirm that detection limits are capable of detecting FALs, and present decision rules.

\section{A.7.1 Population Parameters}

For judgmental sampling results, the population parameter is the observed concentration of each contaminant from each individual analytical sample. Each sample result will be compared to the FALs to determine the appropriate resolution to Decision I and Decision II. For Decision I, a single sample result for any contaminant exceeding a FAL would cause a determination that a COC is present within the CAS.

For probabilistic sampling results, the population parameter is the 95 percent UCL of the average sample concentration of each detected contaminant from all analytical samples from an individual release. The population parameter will be compared to the corresponding FALs to determine the appropriate resolution to Decision I and Decision II. For Decision I, a UCL of the average concentration for any contaminant exceeding a FAL would cause a determination that a COC is present within the CAS.

The Decision II population parameter is an individual analytical result from a bounding sample. For Decision II, a single bounding sample result for any contaminant exceeding a FAL would cause a determination that the contamination is not bounded.

\section{A.7.2 Decision Rules}

The decision rules applicable to both Decision I and Decision II are:

- If COC contamination is inconsistent with the CSM or extends beyond the spatial boundaries identified in Section A.6.2, then work will be suspended and the investigation strategy will be reconsidered. 
- If a COC is present, is consistent with the CSM, and is within spatial boundaries, then the decision will be to continue sampling to define the extent.

The decision rules for Decision I are:

- If the population parameter of any COPC in the Decision I population of interest (defined in Step 4) exceeds the corresponding FAL, then that contaminant is identified as a COC, and Decision II samples will be collected.

- If a COC exists at any CAS, a corrective action will be determined.

- If a waste is present that, if released, has the potential to cause the future contamination of site environmental media, a corrective action will be determined.

- If all COPC concentrations are less than the corresponding FALs, then the decision will be no further action.

The decision rules for Decision II are:

- If the population parameter (the observed concentration of any COC) in the Decision II population of interest (defined in Step 4) exceeds the corresponding FAL, then additional samples will be collected to complete the Decision II evaluation.

- If all bounding COC concentrations are less than the corresponding FALs, then the decision will be that the extent of contamination has been defined in the corresponding lateral and/or vertical direction.

If valid analytical results are available for the waste characterization, bioassessment, and geotechnical samples defined in Section A.9.0, then the decision will be that sufficient information exists to characterize the IDW for disposal, determine potential remediation waste types, and to evaluate the feasibility of remediation alternatives.

\section{A.7.3 Action Levels}

The PALs presented in this section are to be used for site screening purposes. They are not necessarily intended to be used as cleanup action levels or FALs. However, they are useful in screening out contaminants that are not present in sufficient concentrations to warrant further evaluation and, therefore, streamline the consideration of remedial alternatives. The RBCA process used to establish FALs is described in the Industrial Sites Project Establishment of Final Action 
Levels (NNSA/NSO, 2006). This process conforms with NAC Section 445A.227 which lists the requirements for sites with soil contamination. For the evaluation of corrective actions, NAC Section 445A.22705 requires the use of ASTM Method E1739-95 to “conduct an evaluation of the site, based on the risk it poses to public health and the environment, to determine the necessary remediation standards (i.e., FALs) or to establish that corrective action is not necessary” (ASTM, 1995).

This RBCA process defines three tiers (or levels) of evaluation involving increasingly sophisticated analyses:

- Tier 1 Evaluation - Sample results from source areas (highest concentrations) are compared to action levels based on generic (non-site-specific) conditions (i.e., the PALs established in the CAIP). The FALs may then be established as the Tier 1 action levels or the FALs may be calculated using a Tier 2 evaluation.

- $\quad$ Tier 2 Evaluation - Conducted by calculating Tier 2 SSTLs using site-specific information as inputs to the same or similar methodology used to calculate Tier 1 action levels. The Tier 2 SSTLs are then compared to individual sample results from reasonable points of exposure (as opposed to the source areas as is done in Tier 1) on a point by point basis. Total TPH concentrations will not be used for risk-based decisions under Tier 2 or Tier 3 . Rather, the individual chemicals of concern will be compared to the SSTLs.

- Tier 3 Evaluation - Conducted by calculating Tier 3 SSTLs on the basis of more sophisticated risk analyses using methodologies described in Method E1739-95 that consider site-, pathway-, and receptor-specific parameters.

The comparison of laboratory results to FALs and the evaluation of potential corrective actions will be included in the investigation report. The FALs will be defined (along with the basis for their definition) in the investigation report.

\section{A.7.3.1 Chemical PALs}

Except as noted herein, the chemical PALs are defined as the EPA Region 9 Preliminary Remediation Goals (PRGs) for chemical contaminants in industrial soils (EPA, 2004). Background concentrations for RCRA metals and zinc will be used instead of PRGs when natural background concentrations exceed the PRG, as is often the case with arsenic on the NTS. Background is considered the average concentration plus two standard deviations of the average for sediment samples collected by the 
Nevada Bureau of Mines and Geology throughout the Nevada Test and Training Range (formerly the Nellis Air Force Range) (NBMG, 1998; Moore, 1999). For detected chemical COPCs without established PRGs, the protocol used by the EPA Region 9 in establishing PRGs (or similar) will be used to establish PALs. If used, this process will be documented in the investigation report.

\section{A.7.3.2 Total Petroleum Hydrocarbon PALs}

The PAL for TPH is 100 ppm as listed in NAC 445A.2272 (NAC, 2004).

\section{A.7.3.3 Radionuclide PALs}

The PALs for radiological contaminants (other than tritium) are based on the NCRP Report No. 129 recommended screening limits for construction, commercial, industrial land-use scenarios (NCRP, 1999) scaled to 25 mrem/yr dose constraint (Murphy, 2004) and the generic guidelines for residual concentration of radionuclides in DOE Order 5400.5 (DOE, 1993). These PALs are based on the construction, commercial, and industrial land-use scenario provided in the guidance and are appropriate for the NTS based on future land use scenarios as presented in Section A.3.2. The PAL for tritium is based on the UGTA Project limit of 400,000 pCi/L for discharge of water containing tritium (NNSA/NV, 2002b).

Solid media such as concrete and/or structures may pose a potential radiological exposure risk to site workers if contaminated. The radiological PAL for solid media will be defined as the unrestricted-release criteria defined in the NV/YMP Radiological Control Manual (DOE/NV, 2000).

\section{A.7.4 Measurement and Analysis Sensitivity}

The measurement and analysis methods listed in Section A.5.2.2 and in the Industrial Sites QAPP (NNSA/NV, 2002a) are capable of measuring contaminant concentrations at or below the corresponding FALs for each COPC. See Section 6.2.8 for additional details. 


\section{A.8.0 Step 6 - Tolerable Limits on Decision Errors}

The purpose of this step is to specify performance criteria for the decision rule. Setting tolerable limits on decision errors is neither obvious nor easy. It requires the planning team to weigh the relative effects of threat to human health and the environment, expenditure of resources, and consequences of an incorrect decision.

Section 7.1 of the EPA QA/G-4HW guidance states that if judgmental sampling approaches are used, quantitative statements about data quality will be limited to measurement error (EPA, 2000a). Measurement error is influenced by imperfections in the measurement and analysis system. Random and systematic measurement errors are introduced in the measurement process during physical sample collection, handling, preparation, analysis, and data reduction. If measurement errors are not controlled, they may lead to errors in making the DQO decisions.

Limits in decision errors for probabilistic sampling designs are quantitatively set and readily measurable. Hypothesis, therefore, can be tested to ascertain whether a site is contaminated. The use of probabilistic design provides the ability to optimize resources while meeting DQOs.

This section provides an assessment of the possible outcomes of DQO decisions and the impact of those outcomes if the decisions are in error.

The baseline condition (i.e., null hypothesis) and alternative condition for Decision I are:

- $\quad$ Baseline condition - A COC is present.

- Alternative condition - A COC is not present.

The baseline condition (i.e., null hypothesis) and alternative condition for Decision II are as follows:

- $\quad$ Baseline condition - The extent of a COC has not been defined.

- Alternative condition - The extent of a COC has been defined.

Decisions and/or criteria have false negative or false positive errors associated with their determination. The impact of these decision errors and the methods that will be used to control these 
errors are discussed in the following subsections. In general terms, confidence in DQO decisions based on judgmental sampling results will be established qualitatively by:

- The development of and concurrence of CSM (based on process knowledge) by stakeholder participants during the DQO process.

- $\quad$ Testing the validity of the CSM based on investigation results.

- Evaluating the quality of the data based on DQI parameters.

\section{A.8.1 False Negative Decision Error}

The false negative decision error would mean deciding that a COC is not present when it actually is (Decision I) or deciding that the extent of a COC has been defined when it has not (Decision II). In both cases the potential consequence is an increased risk to human health and environment.

\section{A.8.1.1 False Negative Decision Error for Judgmental Sampling}

The false negative decision error (where consequences are more severe) is controlled by meeting these criteria:

- For Decision I, a high degree of confidence that the sample locations selected will identify COCs if present anywhere within the CAS. For Decision II, a high degree of confidence that the sample locations selected will identify the extent of COCs.

- A high degree of confidence that analyses conducted will be sufficient to detect any COCs present in the samples.

- A high degree of confidence that the dataset is of sufficient quality and completeness.

To satisfy the first criterion, Decision I samples must be collected in areas most likely to be contaminated by COCs (supplemented by random samples where appropriate). Decision II samples must be collected in areas that represent the lateral and vertical extent of contamination (above FALs). The following characteristics must be considered to control decision errors for the first criterion:

- $\quad$ Source and location of release

- Chemical nature and fate properties 
- Physical transport pathways and properties

- Hydrologic drivers

These characteristics were considered during the development of the CSMs and selection of sampling locations. The field-screening methods and biasing factors listed in Section A.5.2.1 will be used to further ensure that appropriate sampling locations are selected to meet these criteria. Radiological survey instruments and field-screening equipment will be calibrated and checked according to manufacturer instructions and approved procedures. The investigation report will present an assessment on the DQI of representativeness that samples were collected from those locations that best represent the populations of interest as defined in Section A.6.1.

To satisfy the second criterion, Decision I samples will be analyzed for the chemical and radiological parameters listed in Section 3.2. Decision II samples will be analyzed for those chemical and radiological parameters that identified unbounded COCs. The DQI of sensitivity will be assessed for all analytical results to ensure that all sample analyses had measurement sensitivities (detection limits) that were less than or equal to the corresponding FALs. If this criterion is not achieved, the affected data will be assessed (for usability and potential impacts on meeting site characterization objectives) in the investigation report.

To satisfy the third criterion, the entire dataset, as well as individual sample results, will be assessed against the DQIs of precision, accuracy, comparability, and completeness as defined in the Industrial Sites QAPP (NNSA/NV, 2002a) and in Section 6.2.2. The DQIs of precision and accuracy will be used to assess overall analytical method performance as well as to assess the need to potentially “flag” (qualify) individual contaminant results when corresponding QC sample results are not within the established control limits for precision and accuracy. Data qualified as estimated for reasons of precision or accuracy may be considered to meet the constituent performance criteria based on an assessment of the data. The DQI of completeness will be assessed to ensure that all data needs identified in the DQO have been met. The DQI of comparability will be assessed to ensure that all analytical methods used are equivalent to standard EPA methods so that results will be comparable to regulatory action levels that have been established using those procedures. Strict adherence to established procedures and QA/QC protocol protects against false negatives. To provide information 
for the assessment of the DQIs of precision and accuracy, the following quality control samples will be collected as required by the Industrial Sites QAPP (DOE/NV, 2002):

- Field duplicates (minimum of 1 per matrix per 20 environmental samples)

- Laboratory QC samples (minimum of 1 per matrix per 20 environmental samples or 1 per CAS per matrix, if less than 20 collected)

\section{A.8.1.2 False Negative Decision Error for Probabilistic Sampling}

The false negative error rate for CASs 02-42-01, 02-42-02, 02-99-10, and portions of CASs 03-42-01 and 05-19-02 was established by the DQO meeting participants at 0.05 (or 5 percent probability). Upon validation of the analytical results, statistical parameters will be calculated for each COC identified at each site. Maintenance of a false negative error rate of 0.05 is contingent upon:

- Population distribution

- Sample size

- Actual variability

- Measurement error

Control of the false negative decision error, therefore, for probabilistic sampling designs is accomplished by ensuring that:

- Population distributions of the major contaminants fit the applied UCL determination method.

- A sufficient sample size was collected.

- The actual standard deviation of each major contaminant is calculated.

- Analyses conducted were sufficient to detect any COCs present in samples.

Calculation of sample size is described in Section C.1.2.2, Sample Size.

\section{A.8.2 False Positive Decision Error}

The false positive decision error would mean deciding that a COC is present when it is not, or a COC is unbounded when it is not, resulting in increased costs for unnecessary sampling and analysis. 


\section{A.8.2.1 False Positive Decision Error for Judgmental Sampling}

The false positive decision error is controlled by implementing all the controls that protect against false negative decision errors. False positive results are typically attributed to laboratory and/or sampling/handling errors that could cause cross-contamination. To control against cross-contamination, decontamination of sampling equipment will be conducted according to established and approved procedures and only clean sample containers will be used. To determine whether a false positive analytical result may have occurred, the following quality control samples will be collected as required by the IS QAPP (DOE/NV, 2002):

- Trip blanks (1 per sample cooler containing VOC environmental samples)

- Equipment blanks (1 per sampling event for each type of decontamination procedure)

- Source blanks (1 per source lot per sampling event)

- Field blanks (minimum of 1 per CAS - additional if field conditions change)

\section{A.8.2.2 False Positive Decision Error for Probabilistic Sampling}

For probabilistic sampling, false positive decision error was established by the DQO meeting participants at 0.20 (or 20 percent probability). The false acceptance rate of 20 percent will be used to calculate minimum sample size. The decision to use this rate was based on two factors:

1. To control sampling costs (results in a lower number of required samples)

2. Acceptable knowledge that the risk of a false positive decision is very low based on years of environmental sampling at similar sites that have not resulted in any detectable false positive decisions.

The only effect the false acceptance rate of 20 percent versus a less-conservative rate could potentially have on the decision is to increase the chance of identifying a COC when it does not exist. This could potentially result in an overly conservative decision and would be more (not less) protective of the environment.

This decision error will also be controlled by implementing the controls listed in Section A.8.1 for probabilistic sampling designs. 


\section{A.9.0 Step 7 - Optimize the Design for Obtaining Data}

This section provides the general approach for obtaining the information necessary to resolve Decision I and Decision II. Judgmental and probabilistic sampling schemes will be implemented to select sample locations and evaluate analytical results for CAU 166. Sections A.9.1 through A.9.3 contain general information about collecting Decision I and Decision II samples under judgmental and probabilistic sampling designs, while the subsequent sections provide CAS-specific sampling activities, including proposed sample locations.

\section{A.9.1 Judgmental Sampling}

A judgmental sampling design will be implemented for CASs 18-01-01 and 18-99-03 as well as portions of CASs 03-42-01 and 05-19-02. Because individual sample results, rather than an average concentration, will be used to compare to FALs at the CASs undergoing judgmental sampling, statistical methods to generate site characteristics will not be used. Section 0.4.4 of the EPA Data Quality Objectives Process for Hazardous Waste Site Investigations (EPA, 2000a) guidance states that the use of statistical methods may not be warranted by program guidelines or site-specific sampling objectives. The need for statistical methods is dependent upon the decisions being made. Section 7.1 of the EPA QA/G-4HW guidance states that a nonprobabilistic (judgmental) sampling design is developed when there is sufficient information on the contamination sources and history to develop a valid CSM and to select specific sampling locations. This design is used to confirm the existence of contamination at specific locations and provide information (such as extent of contamination) about specific areas of the site.

All sample locations will be selected to satisfy the DQI of representativeness in that samples collected from selected locations will best represent the populations of interest as defined in Section A.6.1. To meet this criterion for judgmentally sampled sites, a biased sampling strategy will be used for Decision I samples to target areas with the highest potential for contamination, if it is present anywhere in the CAS. Sample locations will be determined based on process knowledge, previously acquired data, or the field-screening and biasing factors listed in Section A.5.2.1. If biasing factors are present in soils below locations where Decision I samples were removed, additional Decision I soil samples will be collected at depth intervals selected by the Site Supervisor based on biasing 
factors to a depth where the biasing factors are no longer present. The Site Supervisor has the discretion to modify the judgmental sample locations, but only if the modified locations meet the decision needs and criteria stipulated in this DQO.

\section{A.9.2 Probabilistic Sampling}

A probabilistic sampling scheme will be implemented to select sample locations and evaluate analytical results at CASs 02-42-01, 02-42-02, 02-99-10, as well as portions of CASs 03-42-01 and 05-19-02. For probabilistically sampled sites, randomly selected sample locations will be chosen, with locations specified by the VSP software (PNNL, 2005). If a location contains a shallow, hard object (e.g., rock, caliche or buried concrete), the Site Supervisor will establish the location at the nearest place that a surface sample can be obtained.

Statistical methods that generate site characteristics will be used at these CASs. The information provided from probabilistic sampling allows for establishing contaminant concentrations that represent the site as a whole.

\section{A.9.3 Decision II Sampling}

To meet the DQI of representativeness for Decision II samples (that Decision II sample locations represent the population of interest as defined in Section A.6.1), judgmental sampling locations at each CAS will be selected based on the outer boundary sample locations where COCs were detected, the CSM, and other field-screening and biasing factors listed in Section A.5.2. In general, sample locations will be arranged in a triangular pattern around the Decision I location or area at distances based on site conditions, process knowledge, and biasing factors. If COCs extend beyond the initial step-outs, Decision II samples will be collected from incremental step-outs. Initial step-outs will be at least as deep as the vertical extent of contamination defined at the Decision I location and the depth of the incremental step-outs will be based on the deepest contamination observed at all locations. A clean sample (i.e., COCs less than FALs) collected from each step-out direction (lateral or vertical) will define extent of contamination in that direction. The number, location, and spacing of step-outs may be modified by the Site Supervisor, as warranted by site conditions. 


\section{A.9.4 Corrective Action Sites 02-42-01, Cond. Release Storage Yd - North; 02-42-02, Cond. Release Storage Yd - South; 02-99-10, D-38 Storage Area}

This section discusses the sampling and analysis design for the following CASs located in Area 2:

- CAS 02-42-01, Cond. Release Storage Yd - North

- CAS 02-42-01, Cond. Release Storage Yd - South

- CAS 02-99-10, D-38 Storage Area

These CASs are combined for discussion of investigation activities because all the CASs are storage yards that no longer have equipment/material present and do not have biasing factors. A probabilistic sampling design will be applied to the CAI for each of these CASs.

Corrective Action Site 02-42-01 covers approximately 81,872 square feet ( $\left.\mathrm{ft}^{2}\right)$ or 1.88 acres of land. The site is not fenced or posted. Corrective Action Site 02-42-02 covers approximately 32,231 $\mathrm{ft}^{2}$ or 0.73 acres of land. The site is not fenced or posted. Corrective Action Site 02-99-10 covers approximately 25,000 $\mathrm{ft}^{2}$ or 0.57 acres of land. A portion of the storage yard is chain-link fenced; however, the storage yard is not posted. All CASs have been radiologically surveyed but there were no elevated readings identified.

Proposed Decision I sample locations were determined and are shown in Figures A.9-1 through A.9-3. Determination of the number and location of samples is presented in Appendix C. The preliminary estimate of the number of samples for each CAS established by the DQO participants required to be taken at each CAS is 10 . All samples will be taken from the surface ( 0 to $0.5 \mathrm{ft}$ bgs).

At CAS 02-99-10, the area is paved, however, in many places the paving has deteriorated. Because this site is paved, samples will be collected below the asphalt. If asphalt is not present, surface samples will be collected (surface 0 to $0.5 \mathrm{ft}$ bgs). The Site Supervisor will use professional judgment to determine if biasing factors (e.g., stains, elevated screening levels) are found during Decision I sampling that might indicate the need to take subsurface Decision II samples.

Sanitary, hazardous, radioactive, and/or mixed waste, if generated, will be managed and disposed of in accordance with DOE orders, DOT regulations, state and federal waste regulations, and agreements and permits between DOE and NDEP. 


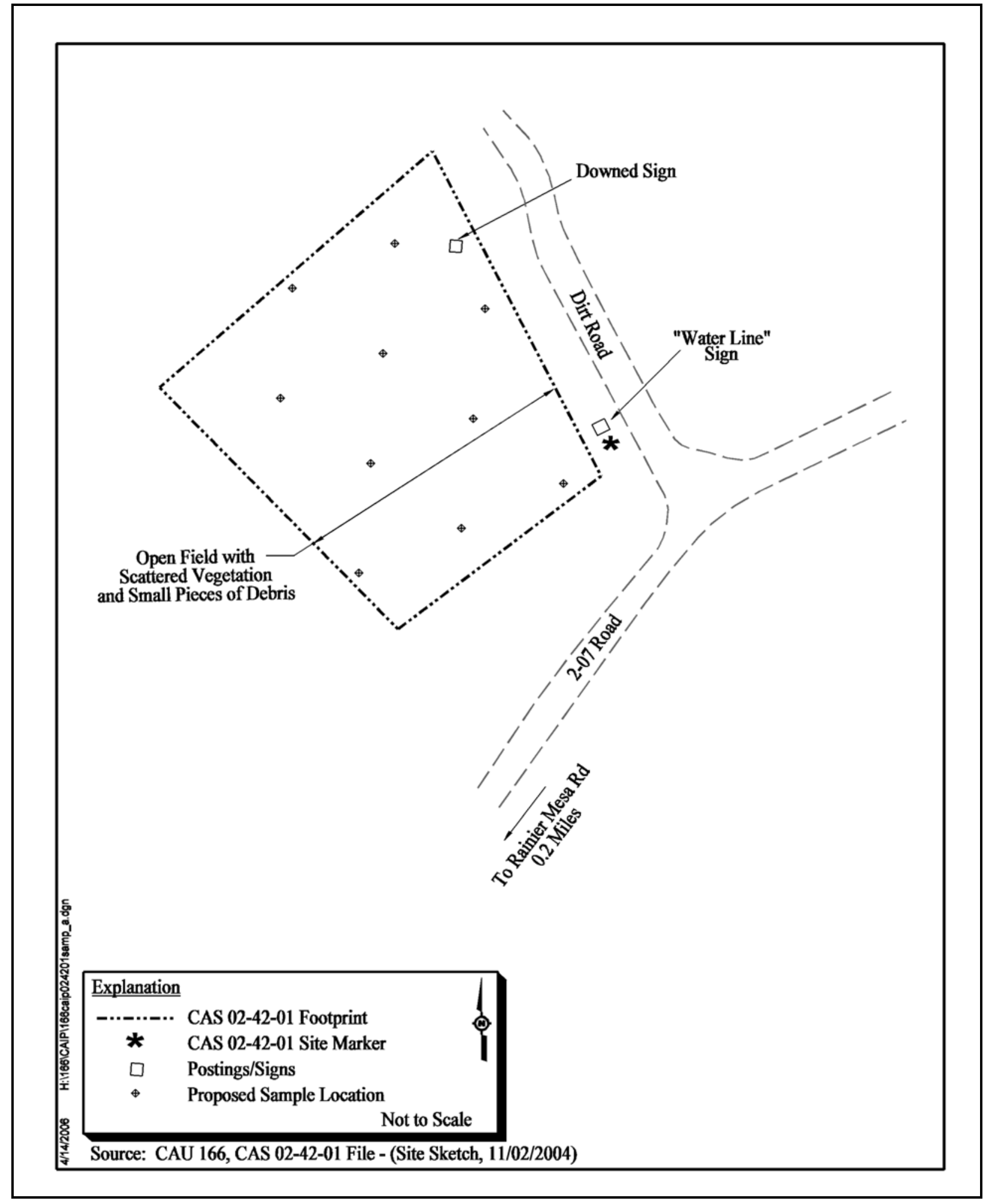

Figure A.9-1

Proposed Sample Locations at CAS 02-42-01 


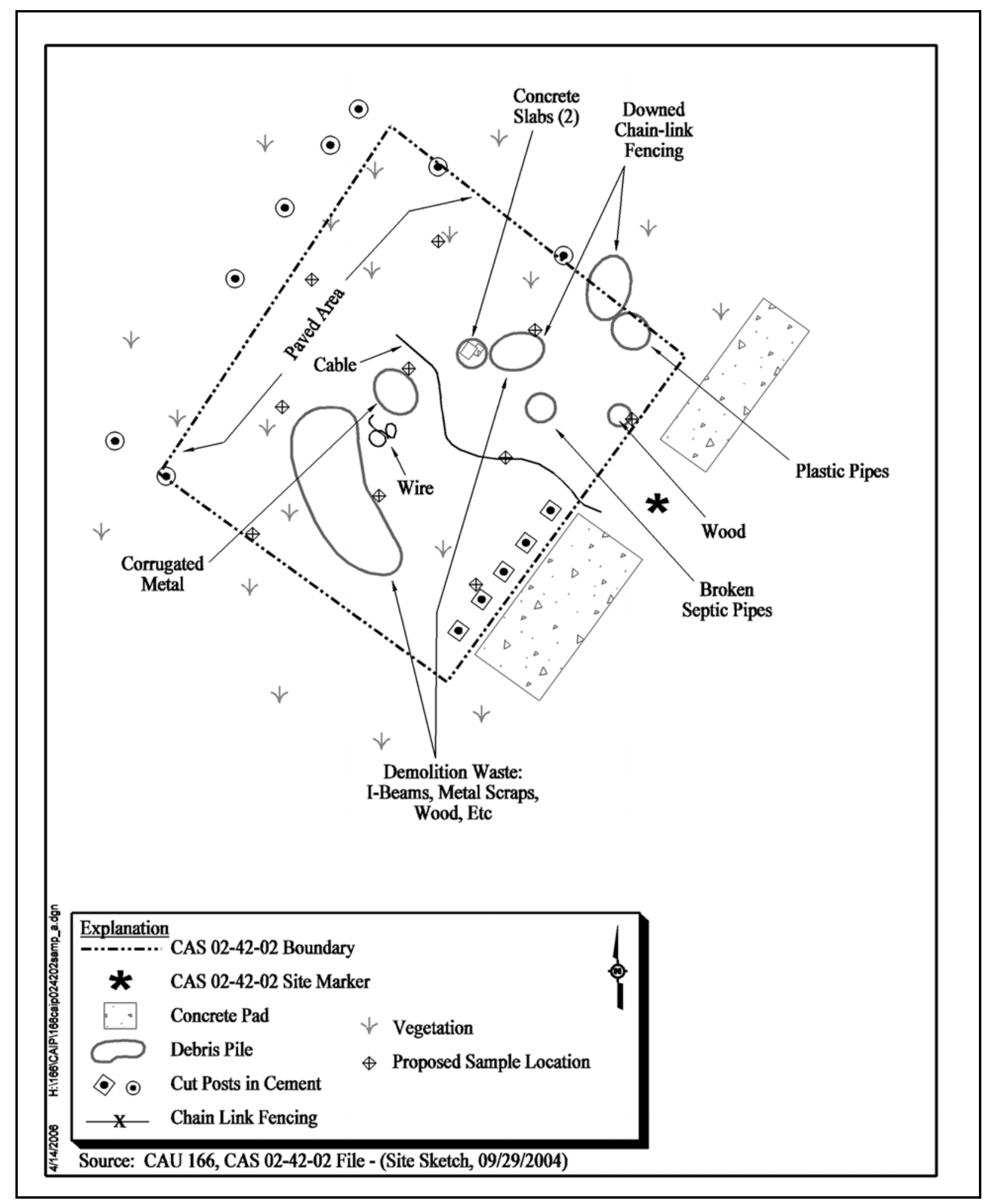

Figure A.9-2

Proposed Sample Locations at CAS 02-42-02 


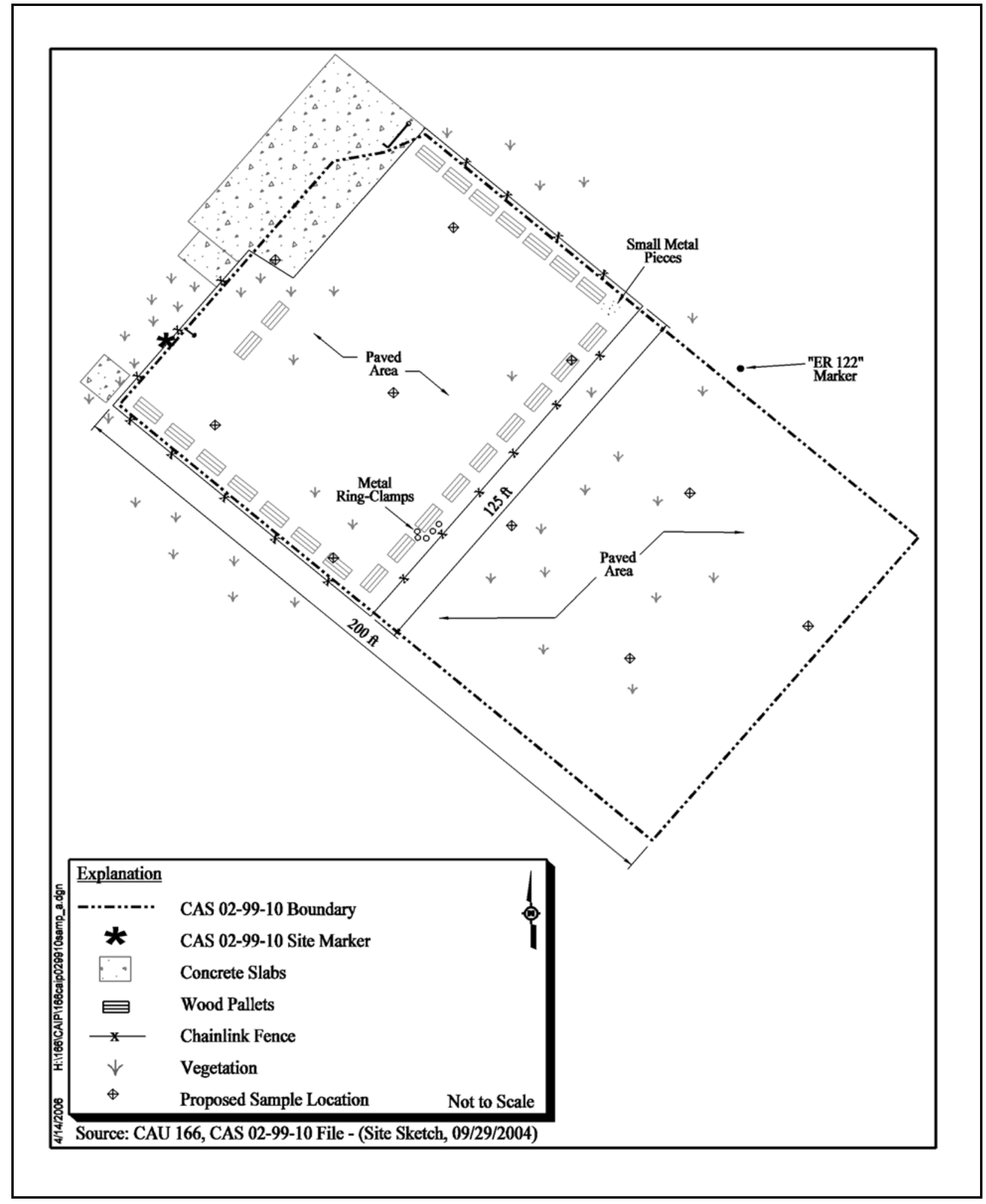

Figure A.9-3

Proposed Sample Locations at CAS 02-99-10 
If Decision II sample step-out locations are required, step-out locations will be established along the CAS boundary.

\section{A.9.5 Corrective Action Site 03-42-01, Conditional Release Storage Yard}

Corrective Action Site 03-42-01 covers approximately 213,826 $\mathrm{ft}^{2}$ or 4.91 acres of land. A portion of this site is fenced and posted “Caution Radioactive Material.” The entire storage yard has been radiologically surveyed; there were no elevated readings identified.

Sampling at this CAS will combine judgmental and probabilistic sampling designs. The portion of the yard that is posted has many biasing factors; therefore, a judgmental sampling design will be implemented. The biasing factors include staining and the presence of potentially radioactive equipment, materials, tanks, portable buildings, and debris. A probabilistic sampling design will be applied to the CAI for the remainder of the storage yard. Although there is a small amount of drilling equipment in this part of the yard, there is no reason to believe there are radiological issues as the equipment is not in the posted area and there is no indication of staining or other biasing factors.

Proposed Decision I sample locations were determined and are shown in Figure A.9-4.

Determination of the number and location of samples for the unposted portion of the yard is presented in Appendix C. The biased sampling locations for the posted portion of the yard will be determined during the CAI since there are still a lot of items that need to be moved from the storage yard prior to sampling the site. The preliminary estimate of sample size established by the DQO participants (Table A.5-1) for the unposted portion of the yard was fifteen samples.

Since this site is paved, samples will be collected below the asphalt. If asphalt is not present, surface samples will be collected (surface 0 to $0.5 \mathrm{ft}$ bgs). The Site Supervisor will use professional judgment to determine if biasing factors (e.g., stains, elevated screening levels) are found during Decision I sampling that might indicate the need to take subsurface Decision II samples.

Sanitary, hazardous, radioactive, and/or mixed waste, if generated, will be managed and disposed of in accordance with DOE orders, DOT regulations, state and federal waste regulations, and agreements and permits between DOE and NDEP. 


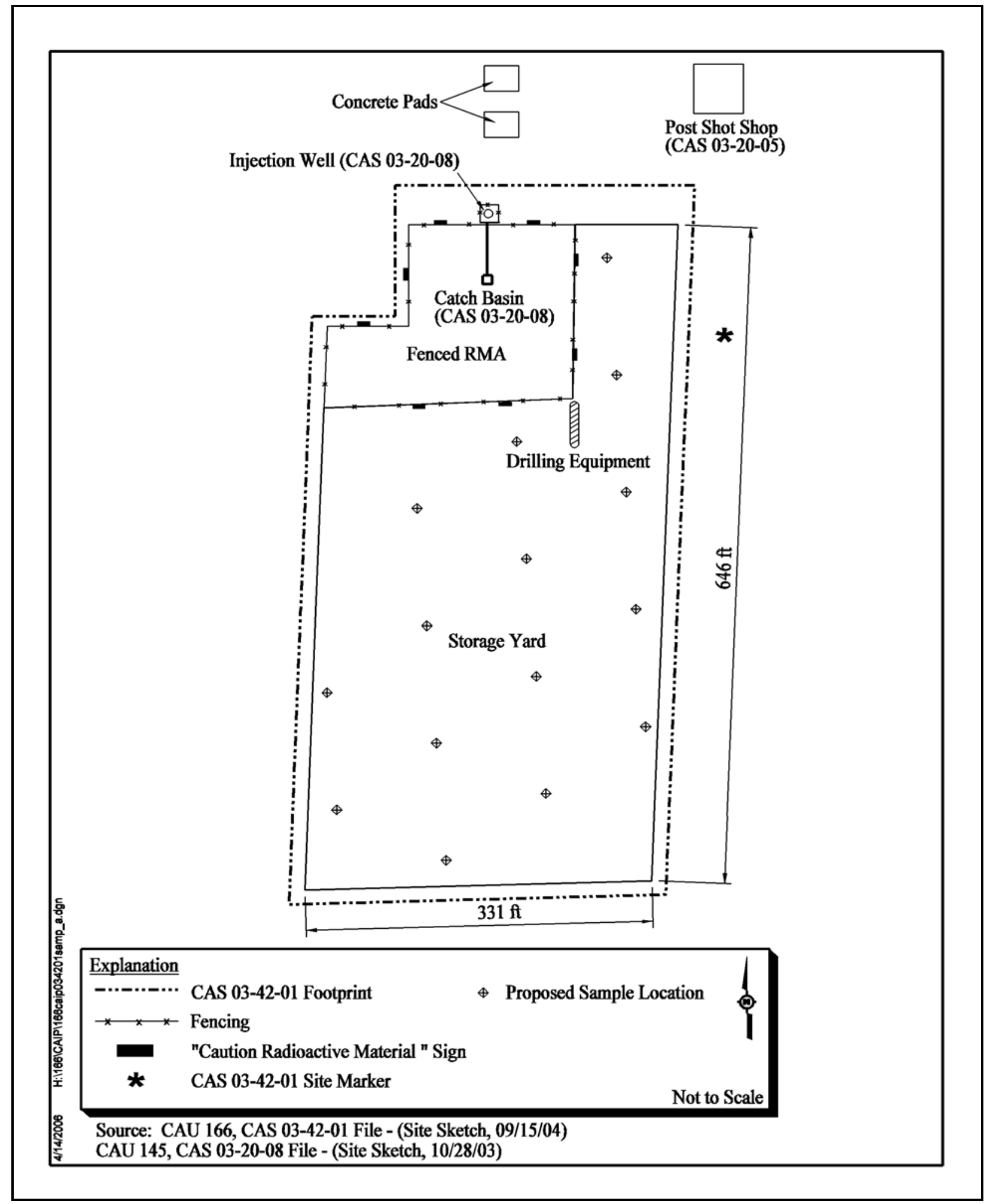

Figure A.9-4

Proposed Sample Locations at CAS 03-42-01 
If Decision II sample step-out locations are required, step-out locations will be established along the CAS boundary.

\section{A.9.6 Corrective Action Site 05-19-02, Contaminated Soil and Drum}

Corrective Action Site 05-19-02 covers approximately 11,340 $\mathrm{ft}^{2}$ or 0.26 acres of land. The storage yard is fenced with barbed wire while the drum is outside of the fenced area in a wash. The yard is not posted. The storage yard and adjacent areas have been radiologically surveyed; there were no elevated readings (Nicosia, 2006).

Sampling at this CAS will involve both judgmental and probabilistic sampling designs. A judgmental sampling design will be conducted in the wash where the drum is located, in the area adjacent to the storage yard where drums were formally stored, and in the area where deteriorated drum remnants are located. A probabilistic sampling design will be applied to the CAI for the storage yard. Although there are vehicles and steel remaining in the yard, there are no biasing factors that indicate where sampling should take place.

Proposed Decision I sample locations were determined and are shown in Figure A.9-5.

Determination of the number and location of samples is presented in Appendix C. The following features will determine the judgmental sampling locations:

- The drum located in the wash will be sampled at two locations. A sample will be collected beneath the drum and a surface sample ( 0 to $0.5 \mathrm{ft}$ bgs) will be collected immediately down gradient (1 to $2 \mathrm{ft}$ ) from the drum.

- The area adjacent to the storage yards where drums were formerly stored will be sampled at two locations. Surface samples (0 to $0.5 \mathrm{ft}$ bgs) will be collected in the suspected area to ensure that an area most likely to contain a COC, if present, will be sampled.

- The area where deteriorated drum remnants remain will be sampled in two locations. Surface samples ( 0 to $0.5 \mathrm{ft}$ bgs) will be collected in the suspected area to ensure that an area most likely to contain a COC, if present, will be sampled.

The preliminary estimate of sample size established by the DQO participants (Table A.5-1) for the storage yard was six samples. If no randomly selected sampling locations fall near the vehicles, a biased sample will be collected in the area of one of the vehicles. The Site Supervisor will use 


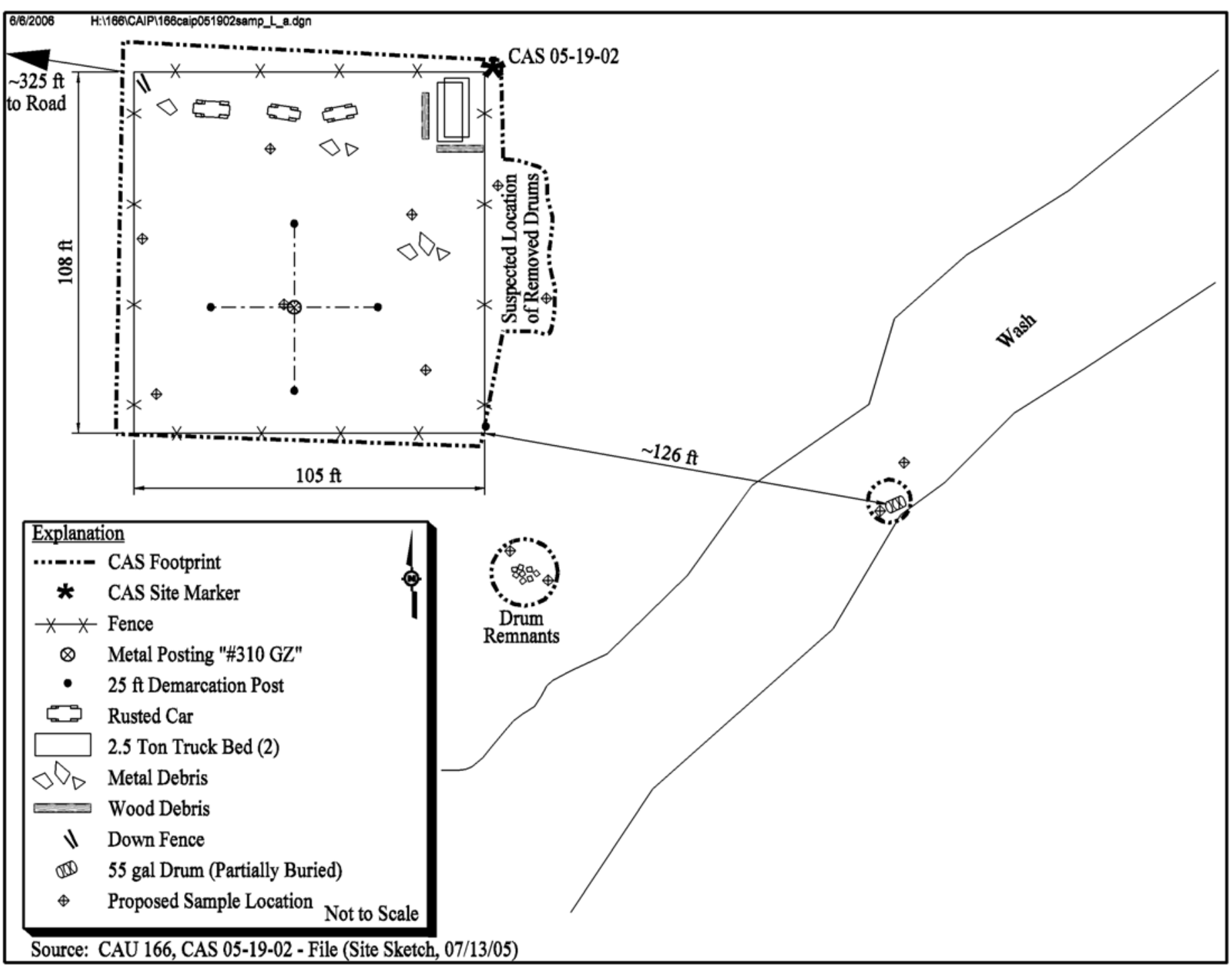

Figure A.9-5

Proposed Sample Locations at CAS 05-19-02

\section{Uncontrolled When Printed}


professional judgment to determine if biasing factors (e.g., stains, elevated screening levels) are found during Decision I sampling that might indicate the need to take subsurface Decision II samples.

Sanitary, hazardous, radioactive, and/or mixed waste, if generated, will be managed and disposed of in accordance with DOE orders, DOT regulations, state and federal waste regulations, and agreements and permits between DOE and NDEP.

If Decision II sample step-out locations are required, step-out locations will be established along the CAS boundary.

\section{A.9.7 Corrective Action Sites 18-01-01, Aboveground Storage Tank, and 18-99-03, Wax Piles/Oil Stain}

This section discusses the sampling and analysis design for the following CASs located in Area 18:

- CAS 18-01-01, Aboveground Storage Tank

- CAS 18-99-03, Wax Piles/Oil Stain

These CASs are combined for discussion of investigation activities because both CASs consists of the same components and have biasing factors. A judgmental sampling design will be applied to the CAI for each of these CASs.

The CASs consist of several features that are considered biasing factors. These features include three metal containers, one metal box, and various wax piles surrounded by hardened residue. The area that the CASs cover is minimal but difficult to determine due to the scattered nature of the components in these CASs. A portion of each of the CASs are within a yellow roped, posted contamination area. The CASs have been radiologically surveyed. A portion of the sites surveyed within the contamination area has elevated gamma radiation. The rest of the areas surveyed did not have elevated readings (Nicosia, 2006).

Proposed Decision I sample locations were determined and are shown in Figures A.9-6 through A.9-8. Determination of the number and location of samples is presented in Appendix C. Four environmental samples will be collected from underneath the metal containers and from underneath the metal box. Two environmental samples will be collected from underneath the wax piles/hardened 
residue; one within and one outside the contamination area. Samples inside the containers and of the wax piles/hardened residue will be collected to determine the potential source of contamination.

Sanitary, hazardous, radioactive, and/or mixed waste, if generated, will be managed and disposed of in accordance with DOE orders, DOT regulations, state and federal waste regulations, and agreements and permits between DOE and NDEP.

If Decision II sample step-out locations are required, step-out locations will be established along the CAS boundary. 


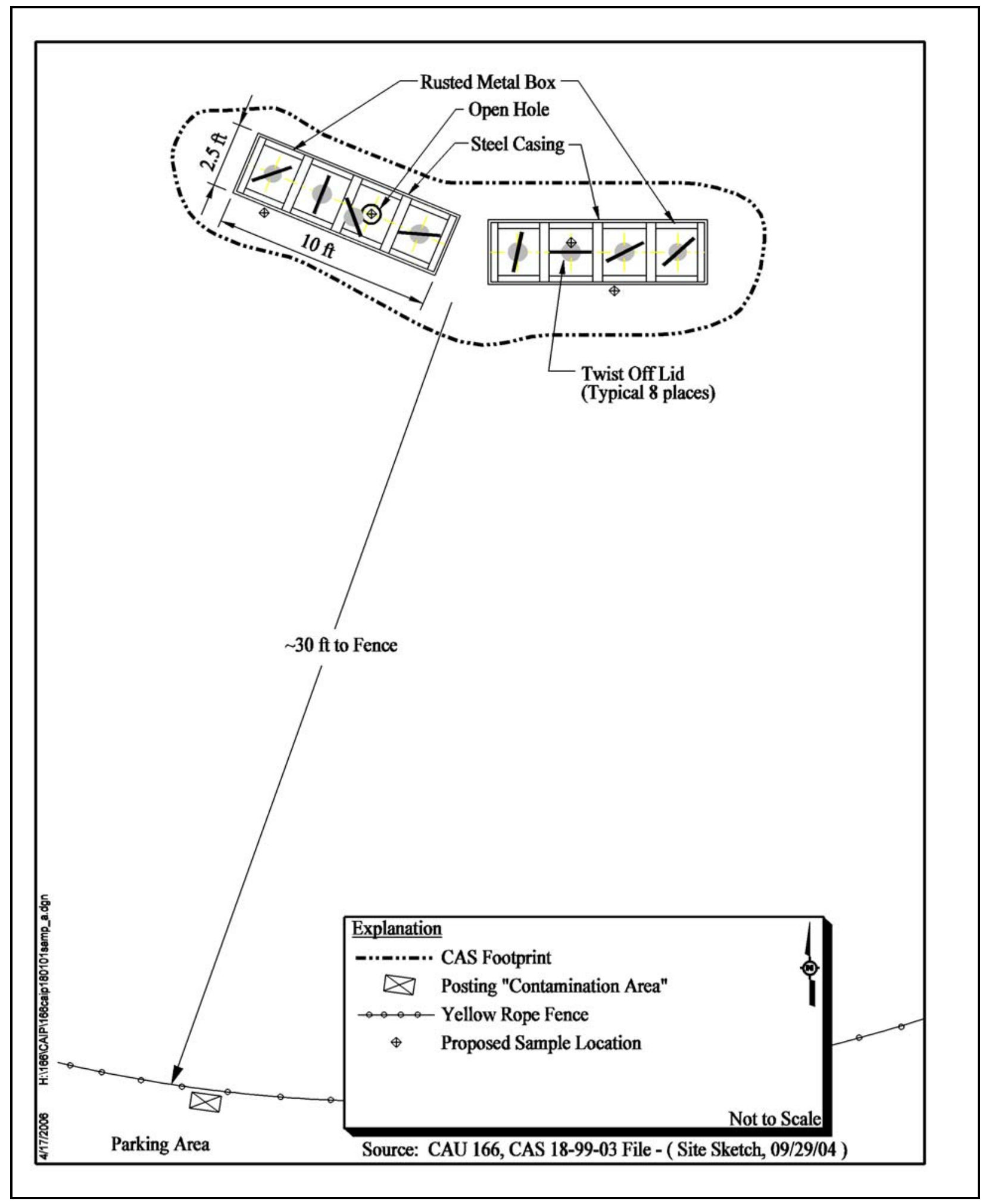

Figure A.9-6

Proposed Sample Locations at CAS 18-01-01 


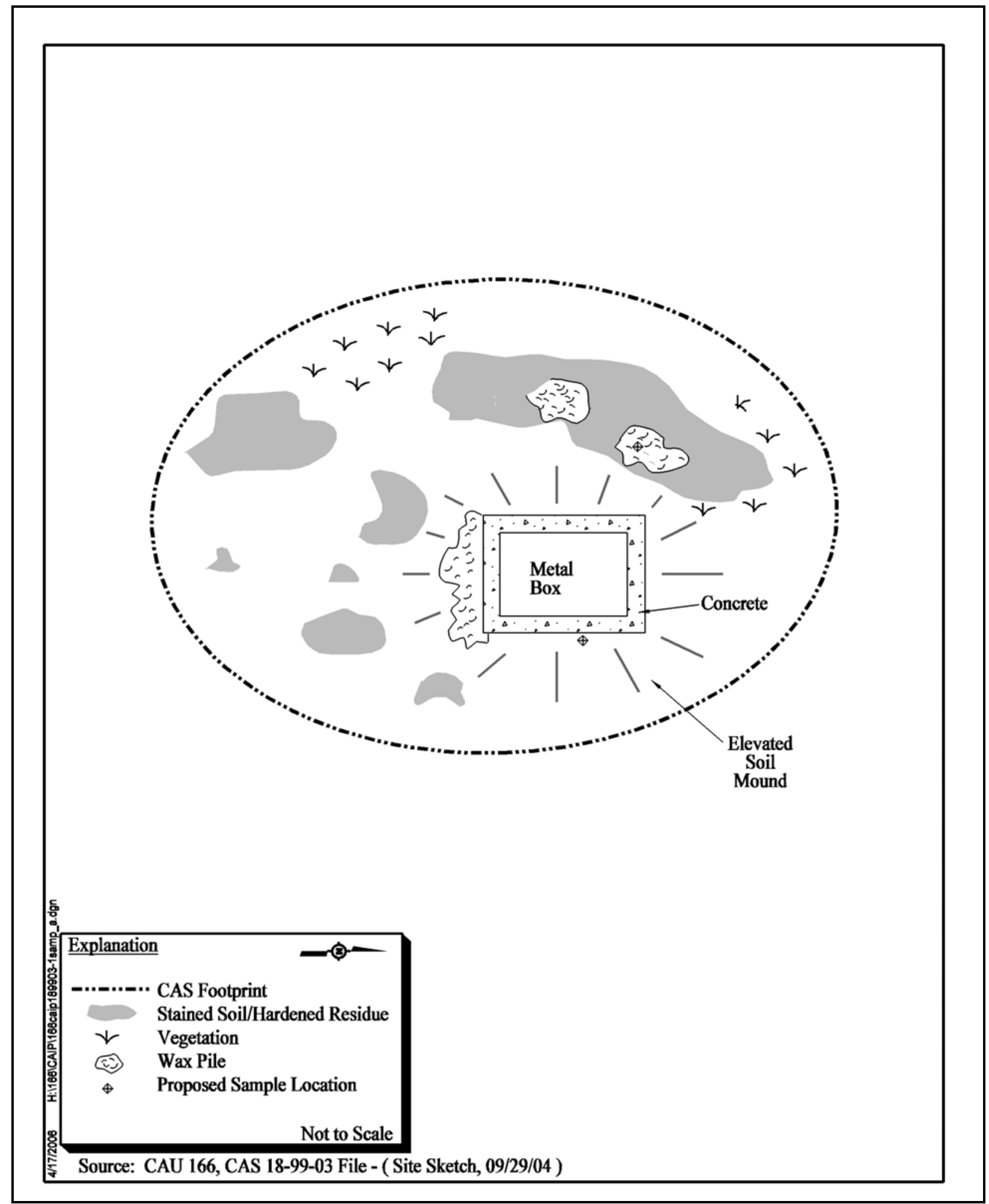

Figure A.9-7

Proposed Sample Locations at Site A, CAS 18-99-03 


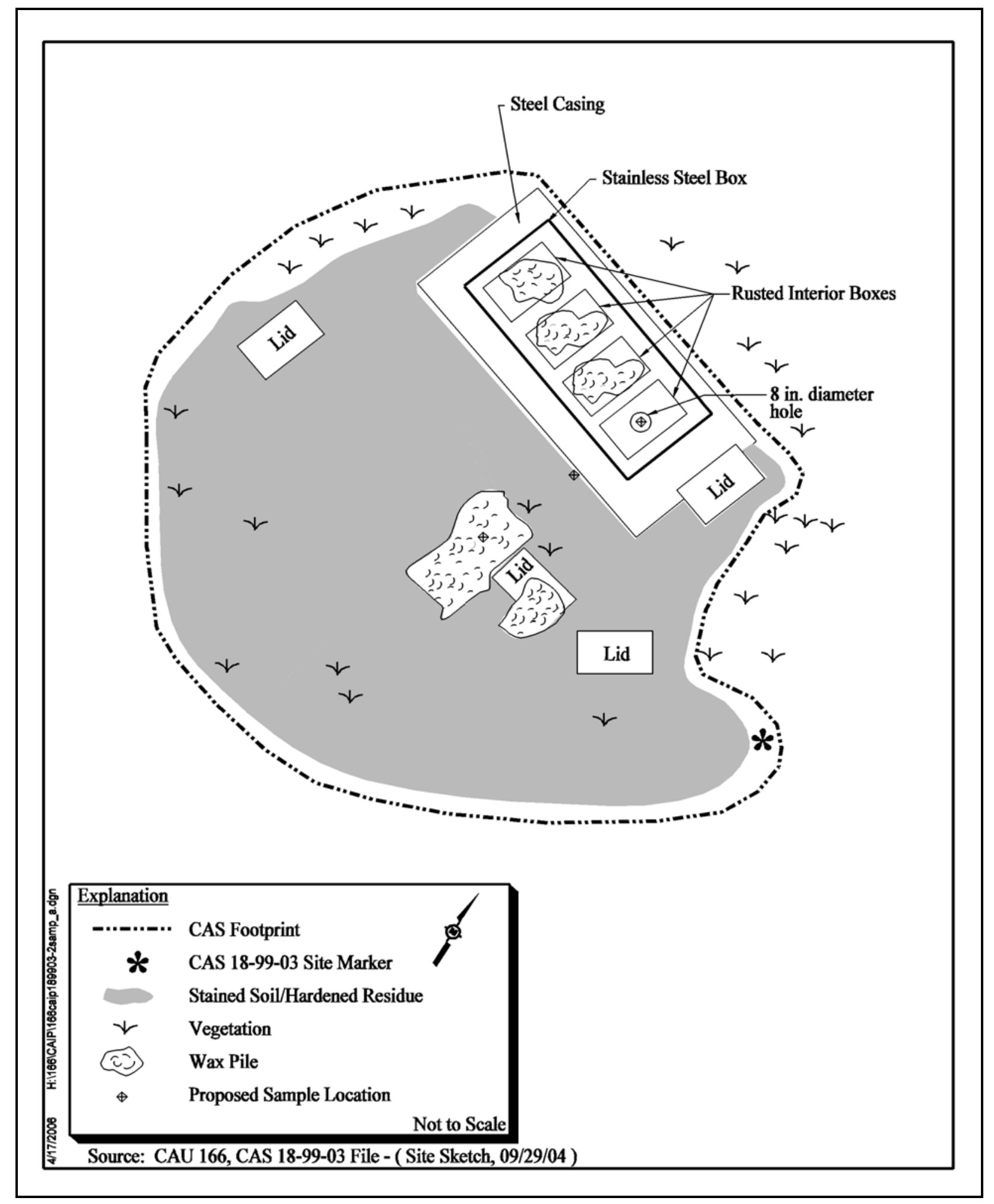

Figure A.9-8

Proposed Sample Locations at Site B, CAS 18-99-03 


\section{A.10.0 References}

ARL/SORD, see Air Resources Laboratory/Special Operations and Research Division.

Air Resources Laboratory/Special Operations and Research Division. 2006. NTS Climatological Rain Gauge Data website. As accessed at http://sord.nv.doe/home_climate_rain.htm on 15 March.

Alderson, S., Stoller-Navarro Joint Venture. 2004. Memorandum to B. Bailey (SNJV) entitled, “Preliminary Assessments Radiological Survey 2004,” 17 February. Las Vegas, NV.

American Society for Testing and Materials. 1995. Standard Guide for Risk-Based Corrective Action Applied at Petroleum Release Sites/American Society for Testing and Materials, ASTM E 1739-95 (Reapproved 2002). Philadelphia, PA.

DOE, see U.S. Department of Energy.

DOE/NV, see U.S. Department of Energy, Nevada Operations Office.

EG\&G Energy Measurements. 1989. Aerial photograph 6612-170 of Area 3 Camp. 23 September. Nellis Air Force Base, NV: Remote Sensing Laboratory Photo Library.

EPA, see U.S. Environmental Protection Agency.

Moore, J., Science Applications International Corporation 1999. Memorandum to M. Todd (SAIC) entitled, "Background Concentrations for NTS and TTR Soils Samples," 3 February. Las Vegas, NV: IT Corporation.

Murphy, T., Bureau of Federal Facilities. 2004. Letter to R. Bangerter (NNSA/NSO) entitled, "Review of Industrial Sites Project Document Guidance for Calculating Industrial Sites Project Remediation Goals for Radionuclides in Soil Using the Residual Radiation (RESRAD) Computer Code.” 19 November. Las Vegas, NV.

NAC, see Nevada Administrative Code.

NBMG, see Nevada Bureau of Mines and Geology.

NCRP, see National Council on Radiation Protection and Measurements.

National Council on Radiation Protection and Measurements. 1999. Recommended Screening Limits for Contaminated Surface Soil and Review of Factors Relevant to Site-Specific Studies/National Council on Radiation Protection and Measurements, NCRP Report No. 129. Bethesda, MD. 
Nevada Administrative Code. 2004. NAC 445A, “Water Controls.” Carson City, NV. As accessed at http://www.leg.state.nv.us/nac on 15 March 2006.

Nevada Bureau of Mines and Geology. 1998. Mineral and Energy Resource Assessment of the Nellis Air Force Range, Open-File Report 98-1. Reno, NV.

Nicosia, W., Stoller-Navarro Joint Venture. 2004. Memorandum to B. Bailey (SNJV) entitled, "Radiological Land Area Surveys of Corrective Action Unit (CAU) 166: Area 2 Storage Yards and Contaminated Materials (Corrective Action Sites [CASs] 02-42-02 and 02-99-10) at the Nevada Test Site,” 17 November. Las Vegas, NV.

Nicosia, W., Stoller-Navarro Joint Venture. 2006. Email to B. Bailey (SNJV) entitled, “CAU 166 Rad Surveys," 6 April. Las Vegas, NV.

NNSA/NV, see U.S. Department of Energy, National Nuclear Security Administration Nevada Operations Office.

Pacific Northwest National Laboratory. 2005. Visual Sample Plan Version 4.0 User’s Guide. PNNL-14002. Richland, WA.

PNNL, see Pacific Northwest National Laboratory.

REECo, see Reynolds Electrical \& Engineering Co., Inc.

Reynolds Electrical \& Engineering Co., Inc. 1991. Nevada Test Site Inventory of Inactive and Abandoned Facilities and Waste Sites, Area 5, DOE/NV/10630-18. Las Vegas, NV.

Shott, G.J., V. Yucel, M.J. Sully, L.E. Barker, S.E. Rawlinson, and B.A. Moore. 1997. Performance Assessment/Composite Analysis for the Area 3 Radioactive Waste Management Site at the Nevada Test Site, Nye County, Nevada, Rev. 2.0. Las Vegas, NV.

Stoller-Navarro Joint Venture. 2004. Digital Photography for CAU 166, CAS 03-42-01. Las Vegas, NV.

Trump, D., Reynolds Electrical \& Engineering Co., Inc. 1991. Memorandum to J.R. Roberts (REECo) entitled, "Master Listing of Cleanup Points from the Inventory of Inactive and Abandoned Facilities and Waste Sites.” June. Las Vegas, NV.

U.S. Department of Energy. 1993. Radiation Protection of the Public and the Environment, DOE Order 5400.5, chg. 2. Washington, DC: U.S. Government Printing Office.

U.S. Department of Energy, National Nuclear Security Administration Nevada Operations Office. 2002a. Industrial Sites Quality Assurance Project Plan, Nevada Test Site, Nevada, Rev. 3, DOE/NV--372. Las Vegas, NV. 
U.S. Department of Energy, National Nuclear Security Administration Nevada Operations Office. 2002b. Underground Test Area Project Waste Management Plan, DOE/NV--343-Rev. 2. Las Vegas, NV.

U.S. Department of Energy, Nevada Operations Office. 1992. Remedial Investigation and Feasibility Study for the Plutonium Contaminated Soils at Nevada Test Site, Nellis Air Force Range and Tonopah Test Range, April. Las Vegas, NV.

U.S. Department of Energy, Nevada Operations Office. 1996. Environmental Impact Statement for the Nevada Test Site and Off-Site Locations in the State of Nevada, DOE/EIS-0243. Las Vegas, NV.

U.S. Department of Energy, Nevada Operations Office. 1998. Nevada Test Site Resource Management Plan, DOE/NV-518. Las Vegas, NV.

U.S. Department of Energy, National Nuclear Security Administration Nevada Site Office. 2004. NV/YMP Radiological Control Manual, Rev. 4, DOE/NV/11718-079. Prepared by Bechtel Nevada. Las Vegas, NV.

U.S. Department of Energy, National Nuclear Security Administration Nevada Site Office. 2006. Industrial Sites Project Establishment of Final Action Levels, Rev. 0, DOE/NV--1107. Prepared by Stoller-Navarro Joint Venture. Las Vegas, NV.

U.S. Environmental Protection Agency. 1989. Risk Assessment Guidance for Superfund: Volume I Human Health Evaluation Manual (Part A, Interim Final). Washington, DC: Office of Emergency and Remedial Response.

U.S. Environmental Protection Agency. 2000a. Data Quality Objectives Process for Hazardous Waste Site Investigations. EPA QA/G-4HW. Washington, DC.

U.S. Environmental Protection Agency. 2000b. Guidance for the Data Quality Objective Process, EPA QA/G4. Washington, DC.

U.S. Environmental Protection Agency. 2002. Guidance for Quality Assurance Project Plans, EPA QA/G5. Washington, DC.

U.S. Environmental Protection Agency. 2004. Region 9 Preliminary Remediation Goals (PRGs). As accessed at http://www.epa.gov/region09/waste/sfund/prg/index.htm on 30 March 2006. Prepared by S.J. Smucker. San Francisco, CA.

USGS, see U.S. Geological Survey.

USGS/DOE, see U.S. Geological Survey and U.S. Department of Energy. 
U.S. Geological Survey. 1967. Geology of Northern Frenchman Flat, Nevada Test Site, Technical Letter NTS-188, 2 June. Prepared by W.J. Carr, G.D. Bath, D.L. Healy, and R.M. Hazelwood. Denver, CO.

U.S. Geological Survey. 1995a. Precipitation Data for Water Years 1992 and 1993 from a Network on Nonrecording Gauges at Yucca Mountain, Nevada. USGS-OFR-95-146. Prepared by D.S. Ambos and A.L. Flint, and J.A. Hevesi for the U.S. Department of Energy, Nevada Operations Office. Las Vegas, NV.

U.S. Geological Survey. 1995b. Selected Ground-Water Data for Yucca Mountain Region, Southern Nevada and Eastern California, Calendar Year 1993. USGS-OFR-158. Prepared by G.S. Hale and C.L. Westenburg. Denver, CO.

U.S. Geological Survey. 2006 and U.S. Department of Energy. "Water Levels” As accessed at http://nwis.waterdata.usgs.gov/nv/nwis/gwlevels on 15 March.

Winograd, I.J., and W. Thordarson. 1975. Hydrology and Hydrochemical Framework, South-Central Great Basin, Nevada-California, with Special Reference to the Nevada Test Site, USGS Professional Paper 712-C. Denver, CO. 


\section{Appendix B}

\section{Project Organization}




\section{B.1.0 Project Organization}

The NNSA/NSO Acting Federal Sub-Project Director Environmental Restoration Project and Task Manager is Sabine Curtis. She can be contacted at (702) 295-0542.

The identification of the project Health and Safety Officer and the Quality Assurance Officer can be found in the appropriate plan. However, personnel are subject to change and it is suggested that the appropriate DOE or Industrial Sites Project Manager be contacted for further information. The Task Manager will be identified in the FFACO Monthly Activity Report before to the start of field activities. 


\section{Appendix C}

\section{Determination of the Number and Location of Random Samples}




\section{C.1.0 Probabilistic Sampling Plan}

\section{C.1.1 Purpose}

A probabilistic (random) sampling design was specified by the DQO meeting participants for CAU 166 at CASs 02-42-01, 02-42-01, 02-99-10, and portions of CASs 03-42-01 and

05-19-02 given the lack of features that would provide sufficient confidence about locations of worst-case contaminant concentrations. Consequently, it was decided that contamination at these sites would be evaluated as a whole rather than as individual locations within the sites. This appendix provides the methodology that will be used to determine the required number of samples, locations of samples to be collected, and statistical tests to be applied to the data upon completion of the CAI.

\section{C.1.2 Methodology}

The objective of the probabilistic sampling design is to determine, with a specified degree of confidence, whether the true average contaminant concentrations at the site in question represent an unacceptable risk to human health and the environment (EPA, 2000). The averages from sample analytical results for each constituent are an estimation of the true average contaminant concentrations. Final action levels represent site contaminant concentrations deemed to pose an unacceptable risk to human health and the environment.

Because the average contaminant concentrations from samples is only an estimate of the true (unknown) average contaminant concentrations, it is uncertain how well the sample averages represent the true averages. If an average contaminant concentration was directly compared to the FAL, a significant difference between the true average and the sample average could lead to making decision errors. To reduce the probability of making a false negative decision error, a conservative estimate of the true average is used to compare to the FAL. This conservative estimate (over-estimation) of the true contaminant concentration averages will be calculated as the 95 percent UCLs of the respective sample contaminant concentration averages. By definition, there will be a 95 percent probability that the true average concentration is less than the 95 percent UCL of the sample mean. 


\section{C.1.2.1 Computation of the Upper Confidence Limit}

The computation of appropriate UCLs depends upon the data distribution, number of samples, variability of the dataset, and skewness associated with the dataset. A statistical package will be used to determine the appropriate probability distribution (e.g., normal, lognormal, gamma) and/or a suitable non-parametric distribution-free method and then to compute appropriate UCLs. To ensure that the appropriate UCL computational method is used, the sample data will be tested for goodness-of-fit to all of the parametric and non-parametric UCL computation methods described in the EPA Guidance Document Calculating the Upper Confidence Limits for Exposure Point Concentrations at Hazardous Waste Sites (EPA, 2002).

A UCL will be calculated for each significant COPC. For this purpose, a significant COPC is defined as any constituent that is detected in any sample at a concentration greater than the PAL.

Computation of an appropriate UCL for each of the significant COPCs requires that a minimum number of samples be collected from random locations at each site and a basic assumption that the:

- Data originate from a symmetric but not necessarily normally distributed, population.

- Estimation of the variability is reasonable and representative of the population being sampled.

- Population values are not temporally or spatially correlated.

\section{C.1.2.2 Sample Size}

A minimum number of samples is required to compute a UCL. This number will be calculated from the actual investigation results for each of the significant COPCs to verify that sufficient samples were collected. The VSP software will be used to calculate minimum sample sizes (PNNL, 2005). This software was developed by Pacific Northwest National Laboratory for the DOE and EPA to determine the minimum number of samples needed to characterize a site based on the type of test to be performed, the distribution of data, variability of the data, and the acceptable false positive and false negative error rates. As agreed by the DQO meeting participants on February 28, 2006, the input parameters to be used in calculating the minimum sample size are a:

- Confidence level that a false negative error will not occur will be set at 95 percent.

- Confidence level that a false positive error will not occur will be set at 80 percent.

- Gray region width of 50 percent of each COPC action level. 
Because the minimum number of samples needed to perform the UCL comparison tests cannot be determined until after investigation results are obtained, the number of samples to be collected during the CAI must be estimated. As agreed by the DQO meeting participants on February 28, 2006, the sample size was determined based on professional judgment due to a lack of available input parameters. Comprehensive radiological surveys were not available at the time of the DQOs. The sample size will be adjusted as necessary once CAI data becomes available. The input parameters that will be used to determine the number of samples to make DQO decisions are summarized in Table C.1-1.

Table C.1-1

Parameter Values for Calculating Sample Size

\begin{tabular}{|c|l|}
\hline Parameter & \multicolumn{1}{|c|}{ Description } \\
\hline \hline Sampling Goal & Compare average to fixed threshold \\
\hline Distribution & $\begin{array}{l}\text { Data not assumed to be normally distributed } \\
\text { Ordinary sampling of symmetric distribution }\end{array}$ \\
\hline Hypothesis & Assume site is dirty \\
\hline False Rejection Rate & $5 \%$ \\
\hline False Acceptance Rate & $20 \%$ \\
\hline Standard Deviation & Actual significant COPC standard deviation \\
\hline Average & Actual significant COPC average concentration \\
\hline Gray Region Width & Average concentration \\
\hline
\end{tabular}

The parameters used to calculate sample size are graphically depicted in the Decision Performance Goal Diagram (Figure C.1-1). The Decision Performance Goal Diagram is provided as an illustration only for sample size justification. Corrective action decisions will be based on the 95th percent UCL as described in Section C.1.2.1.

\section{C.1.2.3 Sample Location Selection}

The location of initial CAI samples will be determined using a triangular grid pattern, based on a starting location that is chosen randomly. If it is determined that additional samples need to be collected based on the determination of minimum sample size using actual sample results, additional sample locations will be determined using the same methodology (five or more samples) or by randomly selecting each sample location (less than five samples). 


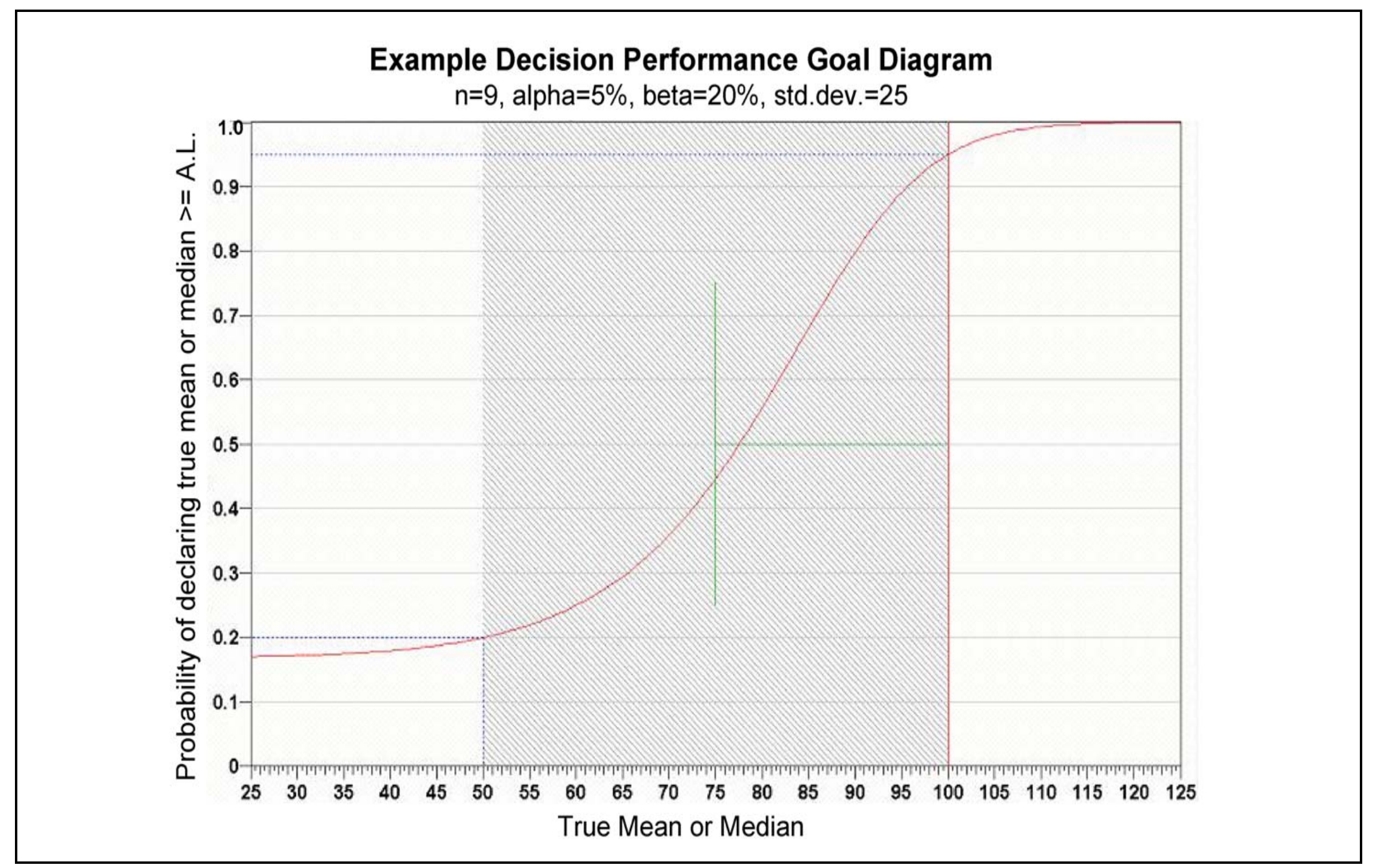

Figure C.1-1

Decision Performance Goal Diagram 


\section{C.2.0 References}

EPA, see U.S. Environmental Protection Agency.

PNNL, see Pacific Northwest National Laboratory.

Pacific Northwest National Laboratory. 2005. Visual Sampling Plan Version 4.0, User's Guide PNNL-14002. Richland, WA.

U.S. Environmental Protection Agency. 2000. Data Quality Objectives Process for Hazardous Waste Site Investigations. EPA QA/G-4HW.

U.S. Environmental Protection Agency. 2002. Calculating Upper Confidence Limits for Exposure Point Concentrations at Hazardous Waste Sites. OWSER 9285.670. December.

Washington, DC: Office of Emergency and Remedial Response 


\title{
Appendix D
}

\section{Nevada Division of Environmental Protection Comments}

\author{
(1 Page)
}




\section{NEVADA ENVIRONMENTAL RESTORATION PROJECT DOCUMENT REVIEW SHEET}

\begin{tabular}{|l|l|}
\hline 1. Document Title/Number: Draft Corrective Action Investigation Plan for Corrective Action unit & 2. Document Date: $05 / 17 / 2006$ \\
166: Storage Yards and Contaminated Materials & 4. Originator/Organization: Stoller-Navarro \\
\hline 3. Revision Number: 0 & 6. Date Comments Due: $05 / 17 / 2006$ \\
\hline 5. Responsible NNSA/NV ERP Project Manager: Sabine Curtis & \\
\hline 7. Review Criteria: Full & 9. Reviewer's Signature:
\end{tabular}

\begin{tabular}{|l|l|l|l|}
\hline $\begin{array}{l}\text { 10. Comment } \\
\text { Number/Location }\end{array}$ & 11. Type* & 12. Comment & 13. Comment Response \\
\hline $\begin{array}{l}\text { 1.) Appendix A, } \\
\text { Page A-45, Table } \\
\text { A.5-1 }\end{array}$ & Mandatory & $\begin{array}{l}\text { NNSA/NSO listed the false acceptance rate as } 20 \% \text { in the } \\
\text { table. This conflicts with the statement on page A-56 of } \\
15 \% \text { in paragraph 2, first sentence, and page C-2 and C-3 } \\
\text { listing values of 20\%. Resolve this. }\end{array}$ & $\begin{array}{l}\text { All references to 15\% were revised to the correct } \\
\text { value of 20\%. }\end{array}$ \\
\hline $\begin{array}{l}\text { 2.) Appendix A, } \\
\text { Page A-54, } \\
\text { Sections A.8.1 and } \\
\text { A.8.2 }\end{array}$ & Mandatory & $\begin{array}{l}\text { Please include for clarity the Decision Performance Goal } \\
\text { Diagram as demonstrated in the EPA's document QA/G-4 } \\
\text { Guidance for the Data Quality Objectives Process in } \\
\text { Section A.8.0, and reference the description in Appendix } \\
\text { C.1.2.2 of why the DQO group selected the decision error } \\
\text { values of 5 and 20\% respectively. }\end{array}$ & $\begin{array}{l}\text { Section A.8.2 was separated into two Sections: } \\
\text { Judgemental Sampling and A.8.2.2 False Positive } \\
\text { Decision Error for Probabilistic Design. Additional } \\
\text { information was added to Section A.8.2.2 to } \\
\text { explain why the decision error values of } 5 \text { and 20\% } \\
\text { are used. A paragraph discussing and referencing } \\
\text { an example Decision Performance Goal Diagram } \\
\text { was placed in Section C.1.2.2. }\end{array}$ \\
\hline
\end{tabular}

\section{Uncontrolled When Printed}




\title{
Library Distribution List
}

\author{
$\underline{\text { Copies }}$ \\ 1 (Uncontrolled) \\ U.S. Department of Energy \\ National Nuclear Security Administration \\ Nevada Site Office \\ Technical Library \\ P.O. Box 98518, M/S 505 \\ Las Vegas, NV 89193-8518 \\ U.S. Department of Energy \\ Office of Scientific and Technical Information \\ 1 (Uncontrolled, electronic copy) \\ P.O. Box 62 \\ Oak Ridge, TN 37831-0062 \\ Southern Nevada Public Reading Facility \\ 2 (Uncontrolled, electronic copies) \\ c/o Nuclear Testing Archive \\ P.O. Box 98521, M/S 400 \\ Las Vegas, NV 89193-8521 \\ Manager, Northern Nevada FFACO \\ 1 (Uncontrolled, electronic copy) \\ Public Reading Facility \\ c/o Nevada State Library \& Archives \\ 100 N Stewart Street \\ Carson City, NV 89701-4285
}

